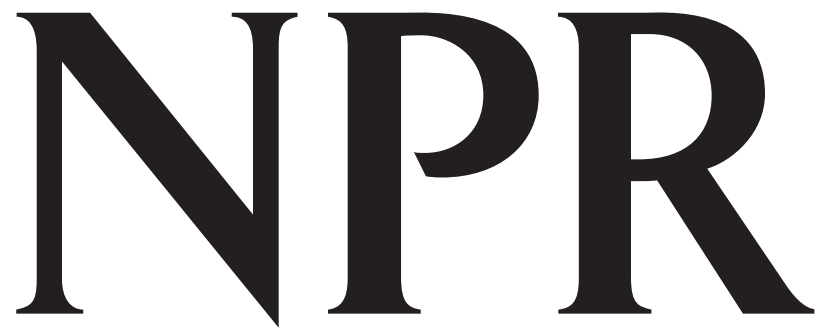

Natural Product Reports

Current developments in natural products chemistry
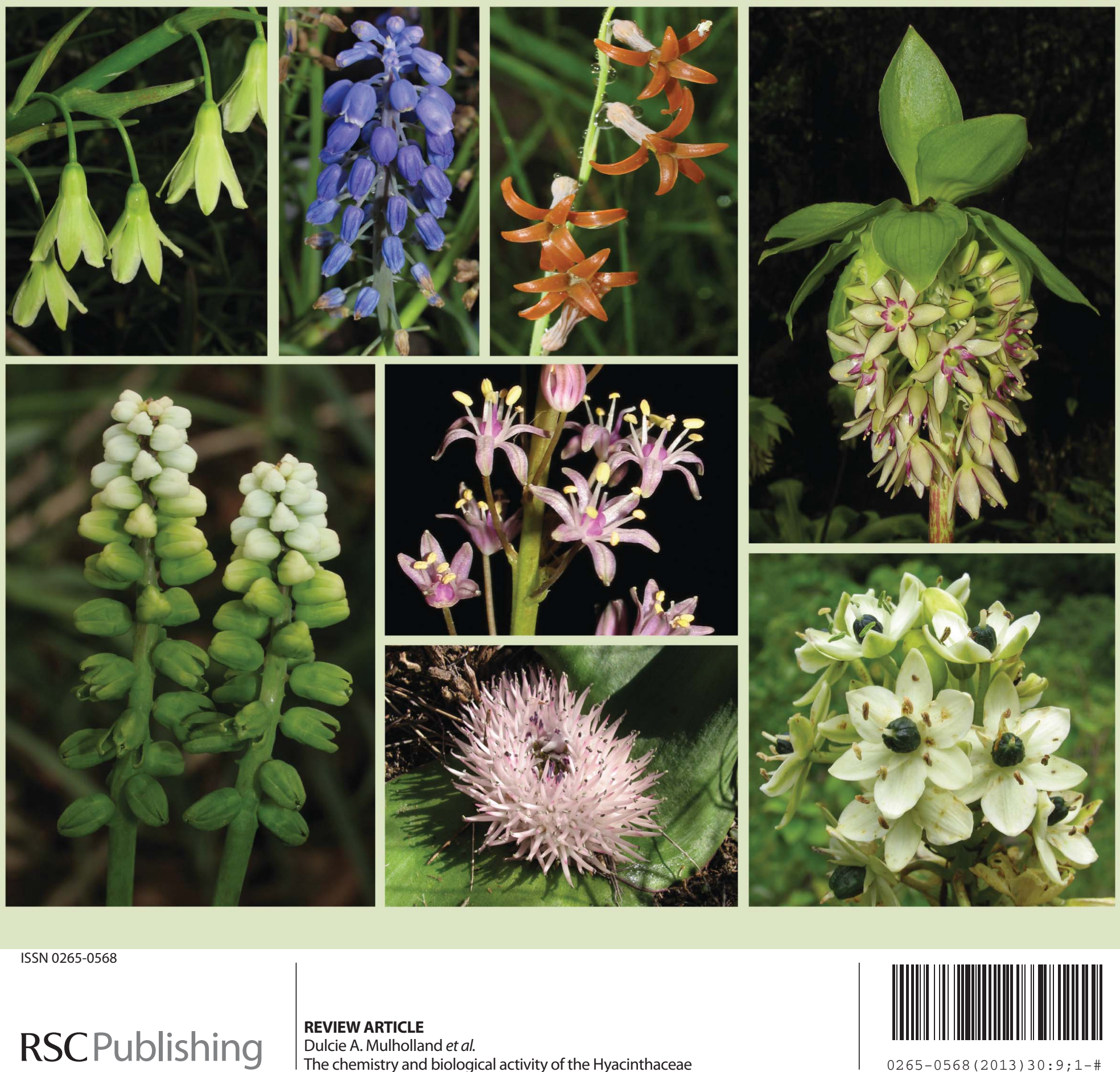
Cite this: Nat. Prod. Rep., 2013, 30 1165

Received 29th January 2013 DOI: $10.1039 / \mathrm{c} 3 n p 70008 a$

www.rsc.org/npr

\section{The chemistry and biological activity of the Hyacinthaceae}

\author{
Dulcie A. Mulholland, ${ }^{\text {ab }}$ Sianne L. Schwikkard ${ }^{\text {ab }}$ and Neil R. Crouch ${ }^{\text {bc }}$
}

Covering: 1914 to 2012

The Hyacinthaceae (sensu APGII), with approximately 900 species in about 70 genera, can be divided into three main subfamilies, the Hyacinthoideae, the Urgineoideae and the Ornithogaloideae, with a small fourth subfamily the Oziroëoideae, restricted to South America. The plants included in this family have long been used in traditional medicine for a wide range of medicinal applications. This, together with some significant toxicity to livestock has led to the chemical composition of many of the species being investigated. The compounds found are, for the most part, subfamily-restricted, with homoisoflavanones and spirocyclic nortriterpenoids characterising the Hyacinthoideae, bufadienolides characterising the Urgineoideae, and cardenolides and steroidal glycosides characterising the Ornithogaloideae. The phytochemical profiles of 38 genera of the Hyacinthaceae will be discussed as well as any biological activity associated with both crude extracts and compounds isolated. The Hyacinthaceae of southern Africa were last reviewed in 2000 (T. S. Pohl, N. R. Crouch and D. A. Mulholland, Curr. Org. Chem., 2000, 4, 1287-1324; ref. 1); the current contribution considers the family at a global level.

\section{The Hyacinthoideae \\ 2 The Urgineoideae \\ 3 The Ornithogaloideae \\ 4 The Oziroëoideae \\ 5 Conclusions \\ 6 Acknowledgements \\ 7 References}

This review reflects a (bracketed) $\dagger$ family and subfamily taxonomic arrangement for the Hyacinthaceae sensu APGII. ${ }^{2}$ A subsequent arrangement (APGIII) $)^{3}$ based on further molecular analyses is not here adopted, where the Hyacinthaceae was hypothetically included in an expanded circumscription of the Asparagaceae. In that the group of plants here dealt with are monophyletic, ${ }^{4}$ the systematic approach adopted for delimiting and naming family, subfamily or tribal level classifications ultimately has little bearing in relation to this review. We have adopted largely the phylogenies and generic concepts of Speta $^{\mathbf{5}}$ Pfosser and Speta, ${ }^{4}$ and

\footnotetext{
${ }^{a}$ Natural Products Research Group, Department of Chemistry, University of Surrey, Guildford, GU2 7XH, United Kingdom

${ }^{b}$ School of Chemistry and Physics, University of KwaZulu-Natal, 4041 Durban, South Africa

${ }^{c}$ Ethnobotany Unit, South African National Biodiversity Institute, P.O. Box 52099, 4007 Berea Road, South Africa

$\uparrow 55$ families under APGII came to be known as 'bracketed families'. These were optional segregates of families that could be circumscribed in a larger sense.
}

subsequent workers (Martínez-Azorín et al. $)^{6}$ who have considered molecular, morphological and biogeographic characters in their circumscriptions. Ali Syed et al. ${ }^{7}$ have provided an excellent overview of alternative and often controversial systematic arrangements, of primary and secondary centres of geographic diversity, and the distribution of subfamilies and tribes at a global level. It should be noted that such is the state of flux of generic circumscription in the Hyacinthaceae that when providing a subfamilial classification for this unit (Asparagaceae subfamily Scilloideae sensu APGIII) Chase et al. ${ }^{8}$ did not list genera names, which they otherwise offered with most other expanded Asparagalean families they treated. Given the past nomenclatural instability of the Hyacinthaceae, the names of plants under which the original phytochemical and pharmacological work was conducted often differs radically from the names accepted currently. For this reason we here provide both current and reported names, with species authors, to make clear this link. The literally reported (and sometimes incorrectly spelt) taxon names and species authors (if given) are provided in parentheses. The subfamilies are discussed in turn, starting with the Hyacinthoideae as most work has been conducted on this, the largest, subfamily. The Urgineoideae and finally the Ornithogaloideae follow. No reported investigations into the Oziroëoideae appear in the literature. Within each subfamily, those species receiving a substantial amount of attention will be discussed first, followed by the genera grouped by region (Europe and the Mediterranean, Middle and Far East and North Africa, southern Africa and finally, in the case of the Urgineoideae, India). 
Plants have been considered on a regional basis as in many cases the secondary metabolites found reflect a strong geographic pattern. Any early work on a genus is discussed before later work.

\section{The Hyacinthoideae}

The subfamily Hyacinthoideae comprises more than 400 species in thirty-eight genera., 5 The Hyacinthoideae are distributed in sub-Saharan Africa, India, Madagascar, eastern Asia, the Mediterranean region and Eurasia. Sub-Saharan Africa appears to be the centre of origin for the subfamily, with a secondary centre of diversification and radiation being the Mediterranean region. ${ }^{7}$ Twenty genera of the Hyacinthoideae have been investigated, with the bulbs receiving most attention. The exception is Hyacinthus orientalis L., the flowers of which have been extensively examined. Homoisoflavanones and spirocyclic nortriterpenoids are widespread throughout the subfamily with chalcones, xanthones, flavonoids, alkaloids, stilbenoids, chromones, norlignans and benzopyranones also being reported.

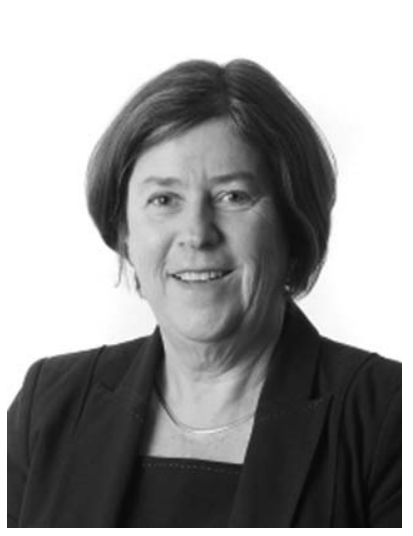

Dulcie Mulholland leads the Natural Products Research Group and is Head of the Department of Chemistry at the University of Surrey. She undertook her PhD at the University of Natal, Durban, South Africa, under the supervision of David Taylor on the Chemistry of the Meliaceae. For the last 20 years she has collaborated with Neil Crouch investigating the phytochemistry of the Hyacinthaceae of southern Africa.

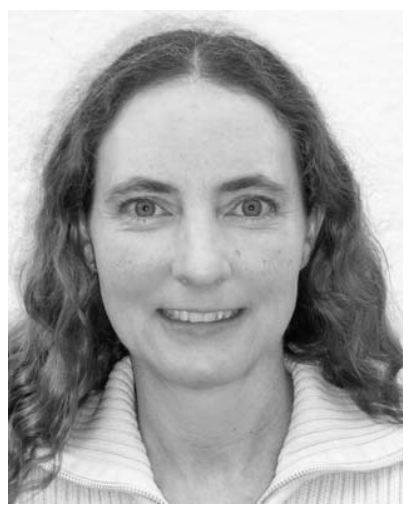

Sianne Schwikkard obtained her PhD from the University of Kwazulu-Natal, South Africa in 1998 (under the supervision of Professor Dulcie Mulholland). This was followed by postdoctoral studies at Virginia Tech with Professor David Kingston and further post-doctoral studies at the Rand Academic University with Professor Fanie van Heerden. After spending 18 months working for Sasol Ltd, Sianne relocated to the United Kingdom and following a postdoctoral position, under Professor Keith Jones at Kingston University, has continued to teach in a part-time capacity at Kingston University in addition to her position as a part-time research associate at the University of Surrey.

Abegaz et al. ${ }^{9}$ and du Toit et al. ${ }^{10}$ have reviewed the phytochemistry, biological activity, biosynthesis and synthesis of the homoisoflavanones. The homoisoflavanones can be divided into five categories, the 3-benzyl-4-chromanones $\mathbf{1}$, the 3-hydroxy-3benzyl-4-chromanones 2, the 3-benzylidene-4-chromanones ( $E$ or $Z$ ) 3, the 3-benzyl-chrom-2-en-4-ones $\mathbf{4}$ and the scillascillins $\mathbf{5}$. The spirocyclic nortriterpenoids are generally of the lanosteroltype, showing a wide range of substitution patterns. The genera receiving the most attention, Eucomis L'Hér., Muscari Mill. and Ledebouria Roth. will be discussed first, followed by the lesserstudied Eurasian and Mediterranean genera Leopoldia Parl., Scilla L., Barnardia Lindl., Othocallis Salisb., Oncostema Raf., Hyacinthus L., Bellevalia Lapeyr., Autonoe (Webb \& Berthel.) Speta and Hyacinthoides Medik. Lastly, the southern African genera Drimiopsis Lindl. \& Paxton, Resnova van der Merwe, Veltheimia Gled., Merwilla Speta, Lachenalia J.Jacq. ex Murray,

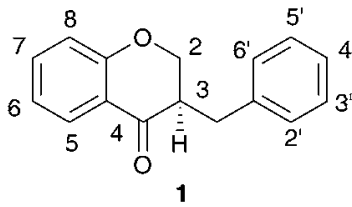<smiles>O=C1c2ccccc2OCC1(O)Cc1ccccc1</smiles><smiles>O=C1/C(=C/c2ccccc2)COc2ccccc21</smiles>

3<smiles>O=C1/C(=C/c2ccccc2)COc2ccccc21</smiles><smiles>O=c1c(Cc2ccccc2)coc2ccccc12</smiles>

4<smiles>O=C1c2ccccc2OC[C@]12Oc1ccccc12</smiles>

5

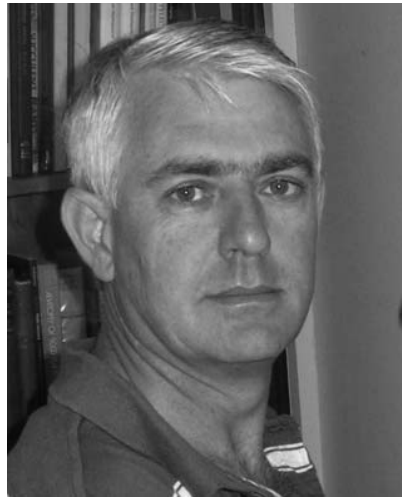

Neil Crouch PhD (Natal) has worked as an ethnobotanist for the South African National Biodiversity Institute (SANBI) for nearly 20 years, largely on Zulu traditional medicine. He networks SANBI in natural products, pharmacological, horticultural, conservation, and Indigenous Knowledge Systems cataloguing programmes and is accordingly involved in statesponsored bioprospecting consortia that develop new drugs for malaria and tuberculosis. As an Honorary Professor in the School of Chemistry and Physics at the University of KwaZulu-Natal, he explores his strong interest in the chemistry, traditional use and biosystematics of the Hyacinthaceae, a plant family with a major centre of diversity in southern Africa. 
Pseudoprospero Speta, Schizocarphus van der Merwe and Spetaea Wetchnig \& Pfosser are dealt with.

The genus Eucomis is widespread throughout eastern and southern Africa. It is used by traditional healers to treat a wide range of complaints, including rheumatism, as an anti-inflammatory and as a treatment for mental disease. Homoisoflavanones and triterpenoid glycosides have been isolated from the bulbs of many of the species investigated, with the homoisoflavanones usually accumulating in the waxy layer between the storage leaves of the bulb and the terpenoids in the bulb tissue. ${ }^{11}$ Early work on Eucomis bicolor Baker resulted in the isolation of the yellow crystalline needles of eucomin 6 and the colourless hexagonal plates of eucomol 7.12 The configuration at C-3 of eucomol 7 was determined by CD experiments and confirmed by $\mathrm{X}$-ray analysis of the $p$-bromophenacyl derivative. ${ }^{13}$ Four additional homoisoflavonoids have been isolated from the bulbs of $E$. bicolor, (8-11) ${ }^{\mathbf{1 4 , 1 5}}$ followed a number of years later by the identification of seven triterpenoid oligosaccharides (12-18).$^{\mathbf{1 6}, \mathbf{1 7}}$ Scillasaponin A 12 has a modified spirocyclic side chain at C-17 and C-23 and has been found to inhibit cyclic AMP phosphodiesterase $\left(\mathrm{IC}_{50}=11.5 \times 10^{-5} \mathrm{M}\right) \cdot{ }^{16}$ Compounds 13,14 and 16 were found to be toxic to HeLa cells at concentrations of both $50 \mu \mathrm{g}$ $\mathrm{ml}^{-1}$ and $5 \mu \mathrm{g} \mathrm{ml}{ }^{-1} \cdot{ }^{17}$ A later investigation of $E$. bicolor resulted in the isolation of twelve compounds from the dichloromethane extract and ten from the methanol extract. The dichloromethane extract yielded the seven known compounds $(7,10,19,20,21,22$ and 23) and five novel triterpenoids (24 [the aglycone of 25], 26, 27, 28 and 29). The methanol extract was found to contain the known homoisoflavonoid $\mathbf{3 0}$ as well as nine novel lanosterol glycosides (31-39). ${ }^{18}$
Eucomis autumnalis (Mill.) Chitt. (syn. Eucomis undulata Aiton) bulbs are used in the Eastern Cape of South Africa to treat cancer, ${ }^{19}$ and are used by Zulu traditional healers as an emetic and enema to treat fevers, as well as for the treatment of skin infections, biliousness, and urinary and respiratory infections. It is also used as a charm against witchcraft. ${ }^{20}$ Phytochemical investigations of the bulbs of E. autumnalis have resulted in the isolation of three homoisoflavanones (40-42), ${ }^{14,21,22}$ two dibenzo- $\alpha$-pyrones (43-44), ${ }^{23}$ two spirocyclic nortriterpenoids (20 and 45) and an acid, compound 46. ${ }^{24}$ The structures assigned to compounds $\mathbf{4 3}$ and $\mathbf{4 4}$ were subsequently revised and reported to be the corresponding xanthones. ${ }^{25}$ The proposed structure for eucosterol 20 was confirmed by the X-ray structure of the $p$-bromobenzenesulphonate derivative. ${ }^{26}$ The extensive use of $E$. autumnalis by traditional healers for fever and the treatment of skin conditions, in particular wounds, boils and open sores, has led to extensive investigations into the anti-inflammatory and antibacterial effects of extracts of the leaves, bulbs and roots. The inhibition of prostaglandin synthesis was assessed in terms of the inhibition of the cyclooxygenase enzymes COX-1 and COX-2. COX-1 is found in normal cells and serves to produce substances that protect the stomach and kidneys (prostanoids). While both enzymes are involved in the inflammatory process, inhibition of COX-1 is associated with gastro-intestinal and kidney related side effects. As such, a higher selectivity for COX-2 inhibition is preferred. ${ }^{27}$ Initial testing of the leaves, bulbs and roots of E. autumnalis against COX-1 showed good activity from all extracts (leaf extract $\mathrm{IC}_{50}=15 \mu \mathrm{g} \mathrm{ml} \mathrm{m}^{-1}$, root extract $27 \mu \mathrm{g} \mathrm{ml} \mathrm{m}^{-1}$ and bulb extract $\left.72 \mu \mathrm{g} \mathrm{ml}{ }^{-1}\right){ }^{28,29} \mathrm{~A}$ comparison of the COX-1 and COX-2<smiles>[R]c1ccc(/C=C2\COc3c([R])c([R])c(O)c(c3O)C2=O)cc1</smiles>

$6 \mathrm{R}_{1}=\mathrm{H}, \mathrm{R}_{2}=\mathrm{OH}, \mathrm{R}_{3}=\mathrm{H}, \mathrm{R}_{4}=\mathrm{OMe}$ $8 \mathrm{R}_{1}=\mathrm{H}, \mathrm{R}_{2}=\mathrm{OMe}, \mathrm{R}_{3}=\mathrm{H}, \mathrm{R}_{4}=\mathrm{OMe}$

$40 \mathrm{R}_{1}=\mathrm{OMe}, \mathrm{R}_{2}=\mathrm{OH}, \mathrm{R}_{3}=\mathrm{H}, \mathrm{R}_{4}=\mathrm{OMe}$ $41 \mathrm{R}_{1}=\mathrm{H}, \mathrm{R}_{2}=\mathrm{OH}, \mathrm{R}_{3}=\mathrm{OMe}, \mathrm{R}_{4}=\mathrm{OH}$ $47 \mathrm{R}_{1}=\mathrm{OMe}, \mathrm{R}_{2}=\mathrm{OH}, \mathrm{R}_{3}=\mathrm{H}, \mathrm{R}_{4}=\mathrm{OH}$ $49 \mathrm{R}_{1}=\mathrm{H}, \mathrm{R}_{2}=\mathrm{OH}, \mathrm{R}_{3}=\mathrm{H}, \mathrm{R}_{4}=\mathrm{OH}$

$53 \mathrm{R}_{1}=\mathrm{OMe}, \mathrm{R}_{2}=\mathrm{OH}, \mathrm{R}_{3}=\mathrm{OH}, \mathrm{R}_{4}=\mathrm{OH}$<smiles>[R]c1ccc(C[C@]2(O)COc3cc([R])cc(O)c3C2=O)cc1</smiles>

$7 \mathrm{R}_{1}=\mathrm{OH}, \mathrm{R}_{2}=\mathrm{OMe}$ $9 \mathrm{R}_{1}=\mathrm{OMe}, \mathrm{R}_{2}=\mathrm{OMe}$ $57 \mathrm{R}_{1}=\mathrm{OH}, \mathrm{R}_{2}=\mathrm{OH}$<smiles>[R]c1ccc(C[C@H]2COc3c([R8])c([R])c([R6])c([R6])c3C2=O)cc1</smiles>

$10 \mathrm{R}_{1}=\mathrm{H}, \mathrm{R}_{2}=\mathrm{OH}, \mathrm{R}_{3}=\mathrm{H}, \mathrm{R}_{4}=\mathrm{OH}, \mathrm{R}_{5}=\mathrm{OMe}$ $11 \mathrm{R}_{1}=\mathrm{H}, \mathrm{R}_{2}=\mathrm{OMe}, \mathrm{R}_{3}=\mathrm{H}, \mathrm{R}_{4}=\mathrm{OH}, \mathrm{R}_{5}=\mathrm{OMe}$ $19 \mathrm{R}_{1}=\mathrm{OMe}, \mathrm{R}_{2}=\mathrm{OH}, \mathrm{R}_{3}=\mathrm{H}, \mathrm{R}_{4}=\mathrm{OH}, \mathrm{R}_{5}=\mathrm{OMe}$ $30 \mathrm{R}_{1}=\mathrm{H}, \mathrm{R}_{2}=\mathrm{OH}, \mathrm{R}_{3}=\mathrm{H}, \mathrm{R}_{4}=\mathrm{OH}, \mathrm{R}_{5}=\mathrm{OH}$ $42 \mathrm{R}_{1}=\mathrm{H}, \mathrm{R}_{2}=\mathrm{OH}, \mathrm{R}_{3}=\mathrm{OMe}, \mathrm{R}_{4}=\mathrm{OH}, \mathrm{R}_{5}=\mathrm{OH}$ $48 \mathrm{R}_{1}=\mathrm{OMe}, \mathrm{R}_{2}=\mathrm{OH}, \mathrm{R}_{3}=\mathrm{H}, \mathrm{R}_{4}=\mathrm{OH}, \mathrm{R}_{5}=\mathrm{OH}$

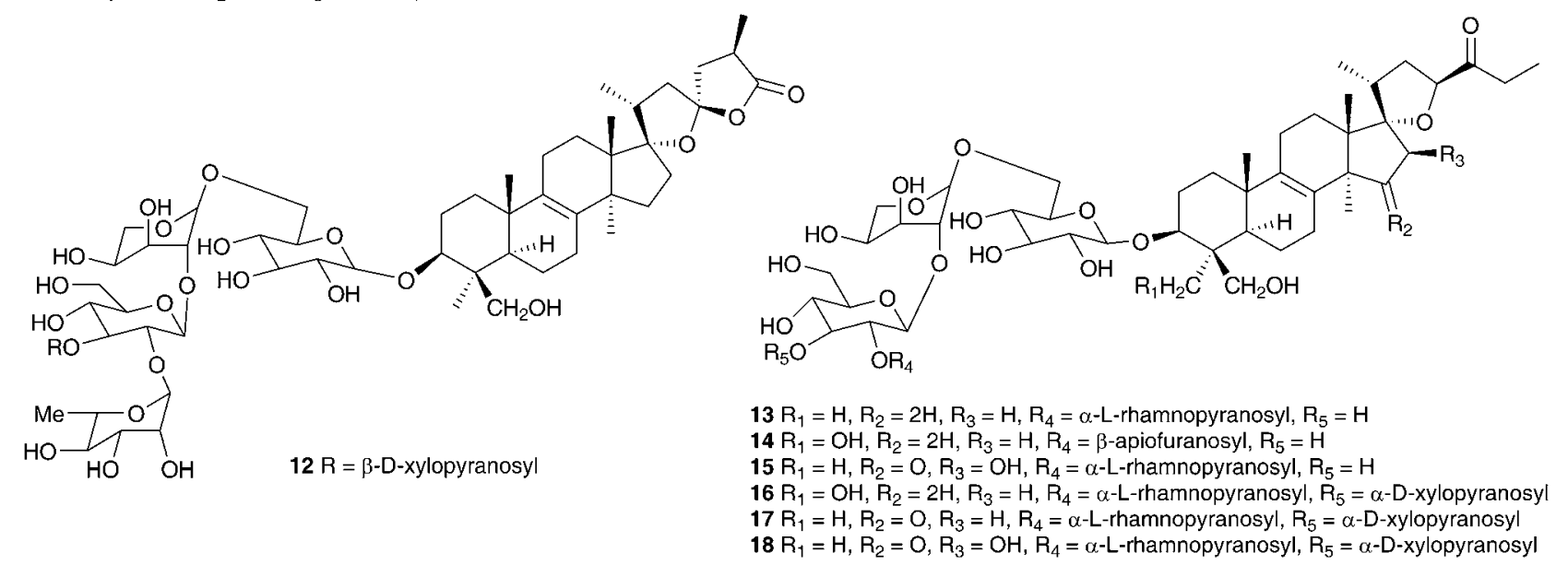




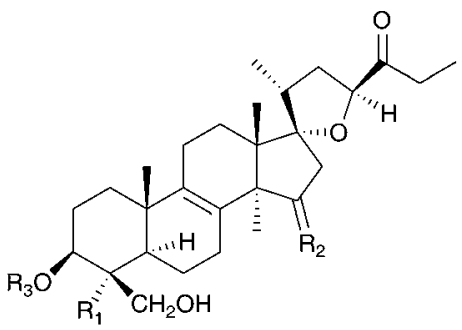

$20 \mathrm{R}_{1}=\mathrm{CH}_{3}, \mathrm{R}_{2}=\mathrm{O}, \mathrm{R}_{3}=\mathrm{H}$

$21 \mathrm{R}_{1}=\mathrm{CH}_{2} \mathrm{OH}, \mathrm{R}_{2}=2 \mathrm{H}, \mathrm{R}_{3}=\mathrm{H}$

$22 \mathrm{R}_{1}=\mathrm{CH}_{3}, \mathrm{R}_{2}=2 \mathrm{H}, \mathrm{R}_{3}=\mathrm{H}$

$31 \mathrm{R}_{1}=\mathrm{CH}_{3} \mathrm{R}_{2}=\mathrm{O}, \mathrm{R}_{3}=\beta$-D-glucopyranoside

$54 \mathrm{R}_{1}=\mathrm{CH}_{2} \mathrm{OH}, \mathrm{R}_{2}=\mathrm{O}, \mathrm{R}_{3}=\mathrm{H}$

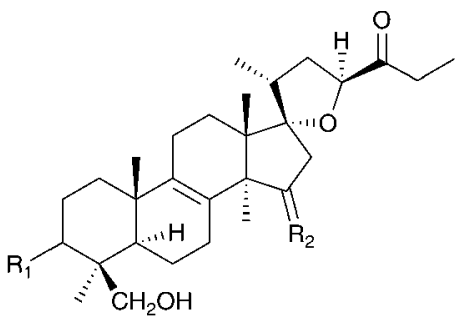<smiles>C[C@H]1CC(=O)O[C@]12CC[C@H]1C3=C(CC[C@]12C)[C@@]1(C)CC[C@H](O)[C@@](C)(CO)[C@@H]1CC3</smiles>

24

$23 \mathrm{R}_{1}==\mathrm{O}, \mathrm{R}_{2}=2 \mathrm{H}$

$32 R_{1}=\beta-O-\beta-D-$ glucopyranoside, $R_{2}=2 H$

$35 R_{1}=\beta$-O- $\beta$-D-arabinopyranosyl- $\beta$-D-glucopyranoside, $R_{2}=0$

$36 \mathrm{R}_{1}=\beta$-O- $\beta$-D-arabinopyranosyl- $\beta$-D-glucopyranoside, $\mathrm{R}_{2}=2 \mathrm{H}$

$39 R_{1}=\beta$-D-arabinopyranosyl- $\left(1^{\prime \prime} \rightarrow 6^{\prime}\right)-\left[\beta-D\right.$-xylopyranosyl- $\left.\left(1^{\prime \prime \prime} \rightarrow 3^{\prime}\right)\right]-\beta$ -

D-glucopyranoside, $\mathrm{R}_{2}=\mathrm{O}$

$63 \mathrm{R}_{1}=\beta-\mathrm{OH}, \mathrm{R}_{2}=\beta-\mathrm{OH}$<smiles>C[C@H]1CC(=O)O[C@]12CC[C@H]1C3=C(CC[C@H]12)[C@]1(C)CCC(=O)[C@H](C)[C@@]1(C)CC3</smiles>

$25 \mathrm{R}=$ - -apiofuranosyl

26

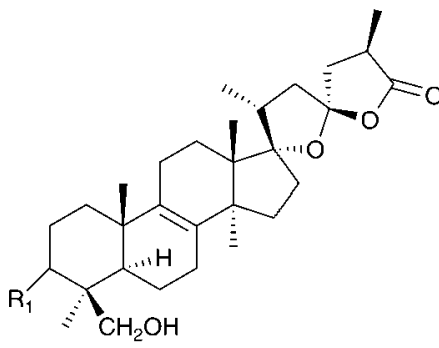

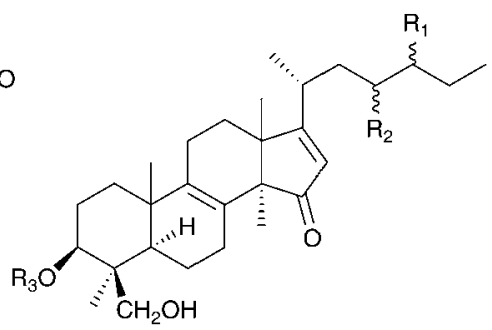

$27 R_{1}==0$

$33 R_{1}=\beta-O-\beta-D-$ glucopyranoside

$38 \mathrm{R}_{1}=\beta-\mathrm{O}-\beta-\mathrm{D}$-arabinopyranosyl- $\beta$ -

D-glucopyranoside

$28 \mathrm{R}_{1}=\mathrm{OH}, \mathrm{R}_{2}=\mathrm{OH}, \mathrm{R}_{3}=\mathrm{H}$

$29 \mathrm{R}_{1}=\mathrm{O}, \mathrm{R}_{2}=\mathrm{OH}, \mathrm{R}_{3}=\mathrm{H}$

$34 R_{1}==O, R_{2}=O H, R_{3}=\beta$-D-glucopyranoside

$37 R_{1}==O, R_{2}=O H, R_{3}=\beta$-D-arabinopyranosyl- $\beta$-D-

glucopyranoside

inhibitory activity of the leaf, root and bulb extracts, showed that the leaf extract inhibited COX-1 to a greater extent while the root and bulb extract showed greater inhibition of COX-2 (COX2/COX-1 of 0.7 and 0.8 respectively for the root and bulb extracts). ${ }^{27,30}$ There has been some interest in the biological effects of plant lectins obtained from the bulbs of E. autumnalis. These non-enzymatic proteins can bind, with high specificity and reversibility, mono- and oligosaccharides. Cyclooxygenase is a membrane-bound glycoprotein and as such could be affected by plant lectins. The partially purified lectin-like protein extract of E. autumnalis was found to have very good cyclooxygenase inhibitory activity (COX-1 inhibition of $88 \%)^{31}$ as well as good activity against the Gram-positive bacterium Bacillus subtilis (MIC of $0.2 \mathrm{mg} \mathrm{ml}^{-1}$ ). ${ }^{32}$ Due to the widespread use of the bulbs of $E$. autumnalis by South African traditional healers, extensive work has been carried out on the factors possibly affecting the effectiveness of the bulb extracts. Environmental factors such as sunlight intensity, temperature and watering as well as age of the bulbs and the effect of cold storage have all been examined. ${ }^{33}$ Bulbs lifted and stored at a low temperature $\left(8-10{ }^{\circ} \mathrm{C}\right)$ showed greater COX-1 inhibitory activity. ${ }^{34}$ The leaves of young plants showed greater COX-1 inhibitory activity than those of older plants, where the greatest activity was associated with bulbs and roots..$^{35}$

Six homoisoflavanones $(19,40,47-50)^{14,36}$ and the optically active 2-hydroxy-2-[(4-hydroxyphenyl)methyl]butanedioic acid 51 have been isolated from the bulbs of Eucomis comosa (Houtt.) H. R. Wehrh. (as Eucomis punctata L'Herit). ${ }^{37}$ The bulb wax of Eucomis comosa yielded the chroman-4-one $\mathbf{5 2}^{\mathbf{3 8}}$ while an examination of the methanol extract of the fresh, air-dried bulbs gave five homoisoflavanones $(\mathbf{4 7}, \mathbf{4 8}, \mathbf{5 0}$ and both the $E$ and $Z$ form of 6$) \cdot{ }^{39}$ The same study included 
<smiles>[2H]c1c(O)cc([N+](=O)[O-])c2oc(=O)c3c(O)cccc3c12</smiles>

$43 \mathrm{R}=\mathrm{H}$

$44 \mathrm{R}=\mathrm{OMe}$

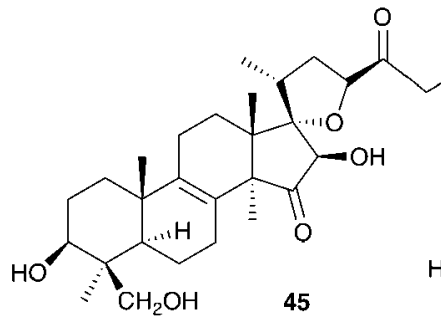

45

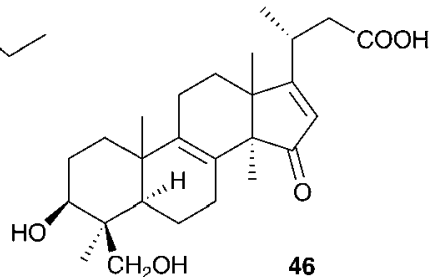

46
Eucomis pallidiflora Baker subsp. pole-evansii (N.E.Br.) Reyneke ex J.C.Manning and Eucomis schijffii Reyneke. The bulbs of Eucomis pallidiflora subsp. pole-evansii contained the homoisoflavanone 53 and the spirocyclic nortriterpenoid 20 while Eucomis schijffii yielded two compounds, the spirocyclic nortriterpenoid $\mathbf{5 4}$ and scillascillin $\mathbf{5 5}{ }^{39}$ Eucomis montana Compton was investigated and the bulbs were found to contain eleven homoisoflavanones $(\mathbf{6}, 7, \mathbf{9}, \mathbf{1 0}, \mathbf{3 0}, \mathbf{5 0}, \mathbf{5 6}, \mathbf{5 7}, \mathbf{5 8}, 59$ and 60). ${ }^{40}$ No inhibitory activity against cyclooxygenase enzymes (COX-1 and COX-2) was found for compounds 48, 53 and 55 isolated from E. comosa, E. pallidiflora and E. schijffii respectively. ${ }^{39}$ Some antibacterial activity has been observed for homoisoflavanones isolated from E. comosa (MIC of $0.52 \mathrm{mM}$ for compound 6 ( $E$ isomer) and $0.24 \mathrm{mM}$ for compound 47 ) and E. schijffii (MIC of $0.50 \mathrm{mM}$ for compound 55). ${ }^{41}$ The dichloromethane and methanol extracts of the whole plant of Eucomis vandermerwei I.Verd. yielded four known homoisoflavanones $\left(6,7,10\right.$ and 56). ${ }^{42}$ Similarly, the whole plant of Eucomis zambesiaca Baker was investigated and this resulted in the isolation and identification of five homoisoflavanones $(6,19,40,61$ and 62$)$ and three nortriterpenoids $(20,21$ and 63$)^{42}$

The bulbs of Muscari racemosum Mill. were found to contain homoisoflavanones of the 3-benzylidene-4-chromanone-type (64-66). ${ }^{43}$ Long-range coupling between $\mathrm{C}-2$ and C-9, was indicative of $Z$ geometry. These homoisoflavanones have been investigated with respect to their effect on lipid peroxidation in vitro. ${ }^{44,45}$ Strong anti-oxidant activity was noted $\left(\mathrm{IC}_{50}=0.94-7.98\right.$ $\mu \mathrm{M})$ and this led to an investigation into their antimutagenic/ anticarcinogenic activity. It has been suggested that polyphenolics may be cancer preventative due to their antioxidant properties $^{44}$ and a mixture of these three homoisoflavanones was found to contain significant antimutagenic activity. ${ }^{44}$ Estrogenic activity was found in an ether extract of the bulbs. The extract induced proliferation of MCF7 cells in a dose dependent manner at concentrations up to $5 \mu \mathrm{g} \mathrm{ml}{ }^{-1}$. This concentration produced the greatest effect of $181 \%$ of the control. ${ }^{46}$<smiles>O=C(O)C[C@](O)(Cc1ccc(O)cc1)C(=O)O</smiles><smiles>COc1c(O)cc(O)c2c1OCCC2=O</smiles><smiles>[R]c1cc(O)c2c(c1)OC[C@H](c1c(C)cc([R3])c([13CH3])c1[R])C2=O</smiles>

$55 \mathrm{R}_{1}=\mathrm{OH}, \mathrm{R}_{2}=\mathrm{H}, \mathrm{R}_{3}-\mathrm{R}_{4}=\mathrm{O}-\mathrm{CH}_{2}-\mathrm{O}$ $60 \mathrm{R}_{1}=\mathrm{OMe}, \mathrm{R}_{2}=\mathrm{H}, \mathrm{R}_{3}=\mathrm{OMe}, \mathrm{R}_{4}=\mathrm{OH}$ $77 \mathrm{R}_{1}=\mathrm{OMe}, \mathrm{R}_{2}=\mathrm{H}, \mathrm{R}_{3}=\mathrm{OH}, \mathrm{R}_{4}=\mathrm{OH}$ $79 \mathrm{R}_{1}=\mathrm{OH}, \mathrm{R}_{2}=\mathrm{H}, \mathrm{R}_{3}=\mathrm{OH}, \mathrm{R}_{4}=\mathrm{OMe}$ $98 \mathrm{R}_{1}=\mathrm{OH}, \mathrm{R}_{2}=\mathrm{H}, \mathrm{R}_{3}=\mathrm{OMe}, \mathrm{R}_{4}=\mathrm{OH}$ $104 \mathrm{R}_{1}=\mathrm{OH}, \mathrm{R}_{2}=\mathrm{H}, \mathrm{R}_{3}=\mathrm{OH}, \mathrm{R}_{4}=\mathrm{OMe}$ $105 \mathrm{R}_{1}=\mathrm{OMe}, \mathrm{R}_{2}=\mathrm{H}, \mathrm{R}_{3}=\mathrm{OH}, \mathrm{R}_{4}=\mathrm{OH}$ $106 \mathrm{R}_{1}=\mathrm{OMe}, \mathrm{R}_{2}=\mathrm{H}, \mathrm{R}_{3}=\mathrm{OMe}, \mathrm{R}_{4}=\mathrm{OH}$ $107 \mathrm{R}_{1}=\mathrm{OMe}, \mathrm{R}_{2}=\mathrm{OH}, \mathrm{R}_{3}=\mathrm{OMe} \mathrm{R}_{4}=\mathrm{H}$<smiles>[2H]c1ccc(CC2COc3c(P)c(P)c(P)c(P)c3C2=O)cc1P</smiles>

$50 \mathrm{R}_{1}=\mathrm{H}, \mathrm{R}_{2}=\mathrm{OH}, \mathrm{R}_{3}=\mathrm{H}, \mathrm{R}_{4}=\mathrm{OMe}, \mathrm{R}_{5}=\mathrm{OH}, \mathrm{R}_{6}=\mathrm{H}$ $56 R_{1}=H, R_{2}=O H, R_{3}=O M e, R_{4}=O M e, R_{5}=O H, R_{6}=H$ $58 \mathrm{R}_{1}=\mathrm{OH}, \mathrm{R}_{2}=\mathrm{OMe}, \mathrm{R}_{3}=\mathrm{H}, \mathrm{R}_{4}=\mathrm{OH}, \mathrm{R}_{5}=\mathrm{OH}, \mathrm{R}_{6}=\mathrm{H}$ $59 \mathrm{R}_{1}=\mathrm{OMe}, \mathrm{R}_{2}=\mathrm{OMe}, \mathrm{R}_{3}=\mathrm{H}, \mathrm{R}_{4}=\mathrm{OH}, \mathrm{R}_{5}=\mathrm{OH}, \mathrm{R}_{6}=\mathrm{H}$ $61 R_{1}=\mathrm{OMe}, R_{2}=\mathrm{OH}, R_{3}=\mathrm{H}, R_{4}=\mathrm{OH}, R_{5}=\mathrm{OH}, R_{6}=\mathrm{H}$ $62 \mathrm{R}_{1}=\mathrm{H}, \mathrm{R}_{2}=\mathrm{OH}, \mathrm{R}_{3}=\mathrm{OMe}, \mathrm{R}_{4}=\mathrm{OH}, \mathrm{R}_{5}=\mathrm{OH}, \mathrm{R}_{6}=\mathrm{H}$

$70 \mathrm{R}_{1}=\mathrm{H}, \mathrm{R}_{2}=\mathrm{OH}, \mathrm{R}_{3}=\mathrm{OMe}, \mathrm{R}_{4}=\mathrm{OH}, \mathrm{R}_{5}=\mathrm{OH}, \mathrm{R}_{6}=\mathrm{OH}$

$71 R_{1}=H, R_{2}=O H, R_{3}=O M e, R_{4}=O H, R_{5}=O H, R_{6}=O M e$ $72 \mathrm{R}_{1}=\mathrm{H}, \mathrm{R}_{2}=\mathrm{OH}, \mathrm{R}_{3}=\mathrm{OMe}, \mathrm{R}_{4}=\mathrm{OH}, \mathrm{R}_{5}=\mathrm{OMe}, \mathrm{R}_{6}=\mathrm{OH}$

$73 \mathrm{R}_{1}=\mathrm{OH}, \mathrm{R}_{2}=\mathrm{OMe}, \mathrm{R}_{3}=\mathrm{H}, \mathrm{R}_{4}=\mathrm{OH}, \mathrm{R}_{5}=\mathrm{OH}, \mathrm{R}_{6}=\mathrm{OH}$

$74 \mathrm{R}_{1}=\mathrm{H}, \mathrm{R}_{2}=\mathrm{OH}, \mathrm{R}_{3}=\mathrm{H}, \mathrm{R}_{4}=\mathrm{OH}, \mathrm{R}_{5}=\mathrm{OH}, \mathrm{R}_{6}=\mathrm{OH}$

$75 \mathrm{R}_{1}=\mathrm{H}, \mathrm{R}_{2}=\mathrm{OH}, \mathrm{R}_{3}=\mathrm{H}, \mathrm{R}_{4}=\mathrm{OMe}, \mathrm{R}_{5}=\mathrm{OH}, \mathrm{R}_{6}=\mathrm{OH}$

$76 R_{1}=H, R_{2}=O H, R_{3}=H, R_{4}=O M e, R_{5}=O M e, R_{6}=O H$

$78 \mathrm{R}_{1}=\mathrm{H}, \mathrm{R}_{2}=\mathrm{OMe}, \mathrm{R}_{3}=\mathrm{H}, \mathrm{R}_{4}=\mathrm{OH}, \mathrm{R}_{5}=\mathrm{OH}, \mathrm{R}_{6}=\mathrm{OH}$

$80 R_{1}=H, R_{2}=O H, R_{3}=H, R_{4}=O H, R_{5}=O M e, R_{6}=O H$

$97 \mathrm{R}_{1}=\mathrm{OH}, \mathrm{R}_{2}=\mathrm{OMe}, \mathrm{R}_{3}=\mathrm{OMe}, \mathrm{R}_{4}=\mathrm{OH}, \mathrm{R}_{5}=\mathrm{OH}, \mathrm{R}_{6}=\mathrm{H}$, 
<smiles>[R]c1c([R])c([R8])c2c(c1[R])OC/C(=C\c1ccc(O)c(O)c1)C2=O</smiles>

$64 \mathrm{R}_{1}=\mathrm{H}, \mathrm{R}_{2}=\mathrm{OH}, \mathrm{R}_{3}=\mathrm{OMe}, \mathrm{R}_{4}=\mathrm{OH}$, $65 \mathrm{R}_{1}=\mathrm{H}, \mathrm{R}_{2}=\mathrm{OH}, \mathrm{R}_{3}=\mathrm{H}, \mathrm{R}_{4}=\mathrm{OMe}$,$$
\mathrm{R}_{1}=\mathrm{OH}_{2} \mathrm{R}_{2}=\mathrm{OM}, \mathrm{R}_{3}=\mathrm{H}_{1} \mathrm{R}_{4}=\mathrm{OH}
$$<smiles>O=c1cc(-c2ccc(O)cc2)oc2cc(O)cc(O)c12</smiles>

$67 \mathrm{R}=\beta$-D-arabinopyranoside $68 \mathrm{R}=\beta$-D-xylospyranoside
$69 \mathrm{R}=\beta$-D-glucopyranoside

A wide range of compounds has been isolated from the bulbs of Muscari armeniacum Leichtlin ex Baker. These include flavonoids (67-69), ${ }^{47}$ homoisoflavanones, with an unusual $3^{\prime}, 4^{\prime}$ substitution pattern in the B ring $(30,62,70-80),{ }^{48,49}$ spirocyclic nortriterpenoid glycosides $(\mathbf{8 1 - 8 7})^{50}$ and polyhydroxylated pyrrolizidine alkaloids (88-92). ${ }^{51}$ The alkaloids were assessed for their action against glycosidases. Compound $\mathbf{8 8}$ was found to be a potent inhibitor of rat intestine lactase $\left(\mathrm{IC}_{50}=4.4 \mu \mathrm{M}\right)$ as well as a moderate inhibitor of $\alpha$-L-fucosidase $\left(\mathrm{IC}_{50}=46 \mu \mathrm{M}\right)$ and amyloglucosidase $\left(\mathrm{IC}_{50}=25 \mu \mathrm{M}\right)$. Inverting the hydroxyl group at C-1 to give compound 89, enhanced the amyloglucosidase inhibition $\left(\mathrm{IC}_{50}=8.6 \mu \mathrm{M}\right)$ but resulted in the loss of the $\alpha$-L-fucosidase inhibition. Compounds 90 and 91 were less active. ${ }^{51}$ Three ribosome-inactivating proteins have been isolated from the bulbs of $M$. armeniacum. It has been proposed that this type of activity is linked to an anti-viral response. ${ }^{52}$ The petals of $M$. armeniacum have yielded four anthocyanins, the new muscarinin A 93 and the known 3-O- $\beta$ D-glucopyranoside of delphinidin, petunidin and malvidin (9496). ${ }^{53-55}$ The principle water soluble polysaccharide in the bulbs of $M$. armeniacum (as Muscari szovitsianum Baker) was found to be a neutral glucofructan, with glucose and fructose residues in the ratio $26: 1 .^{56,57}$

Phytochemical investigations into the bulbs of Muscari botryoides (L.) Mill. confirmed a close taxonomic relationship with Muscari armeniacum. Similar homoisoflavanones (19, 30, $\mathbf{5 8}, \mathbf{6 0}, \mathbf{7 7}, \mathbf{7 9}, \mathbf{9 7}, \mathbf{9 8})^{\mathbf{4 8}}$ were isolated as well as similar spirocyclic nortripertenoid glycosides $(86,87,99,100,101,102$, 103). ${ }^{50}$ Muscari neglectum Guss. ex Ten. was found to contain a similar spread of homoisoflavanones in the bulbs $(\mathbf{3 0}, \mathbf{6 2}, \mathbf{8 0}$, 104-107) as well as an interesting scillascillin-type homoisoflavanone with an unusual oxygenation pattern in the B ring (55) ${ }^{58}$ Ethanol extracts of the bulbs and leaves of Muscari neglectum have been tested for antifungal activity against the wood rots Postia placenta and Trametes versicolor. Significant reduction in wood weight loss was observed for Turkish oriental beech and Scots pine (weight loss dropped from $35-42 \%$ in the untreated wood to $5.4-18.3 \%$ in the treated wood). ${ }^{59}$

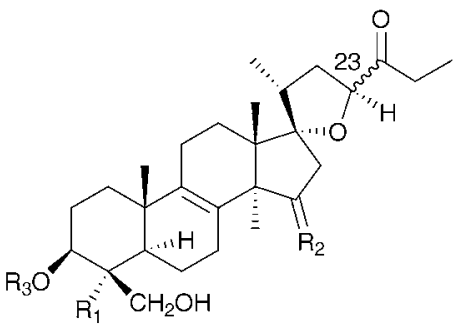

81 (23R) $\mathrm{R}_{1}=\mathrm{CH}_{3} \mathrm{R}_{2}=\mathrm{O}, \mathrm{R}_{3}=\beta$-D-glucopyranoside

82 (23R) $\mathrm{R}_{1}=\mathrm{CH}_{3} \mathrm{R}_{2}=\mathrm{O}, \mathrm{R}_{3}=\alpha$-L-arabinopyranosyl- $(1 \rightarrow 3)$ - $\alpha$-L-rhamnopyranosyl- $(1 \rightarrow 2)-\beta-\mathrm{D}$ glucopyranoyl- $(1 \rightarrow 2)-\alpha-L$-arabinopyranosyl-(1 $\rightarrow 6)-\beta$-D-glucopyranoside 83 (23R) $R_{1}=C_{3} R_{2}=O, R_{3}=\beta$-D-glucopyranosyl- $(1 \rightarrow 2)$ - $\alpha$-L-arabinopyranosyl- $(1 \rightarrow 3)-\alpha-L$ rhamnopyranosyl- $(1 \rightarrow 2)$ - $\beta$-D-glucopyranoyl- $(1 \rightarrow 2)-\alpha$-L-arabinopyranosyl- $(1 \rightarrow 6)-\beta$-Dglucopyranoside 84 (23S) $\mathrm{R}_{1}=\mathrm{CH}_{2} \mathrm{OH}, \mathrm{R}_{2}=2 \mathrm{H}, \mathrm{R}_{3}=\beta$-D-glucopyranoyl- $(1 \rightarrow 2)$ - $\alpha$-L-arabinopyranosyl-(1 $\left.\rightarrow 6\right)-\beta$-D glucopyranoside

85 (23S) $\mathrm{R}_{1}=\mathrm{CH}_{2} \mathrm{OH}, \mathrm{R}_{2}=2 \mathrm{H}, \mathrm{R}_{3}=\alpha$-L-rhamnopyranosyl- $(1 \rightarrow 2)-\beta$-D-glucopyranoyl- $(1 \rightarrow 2)-\alpha$ - Larabinopyranosyl- $(1 \rightarrow 6)-\beta$-D-glucopyranoside

86 (23R) $\mathrm{R}_{1}=\mathrm{CH}_{3}, \mathrm{R}_{2}=\mathrm{O}, \mathrm{R}_{3}=\alpha$-L-rhamnopyranosyl $(1 \rightarrow 2)-\beta$-D-glucopyranosyl $(1 \rightarrow 2)-\alpha-L$ arabinopyranosyl- $(1 \rightarrow 6)-\beta$-D-glucopyranoside 87 (23R) $\mathrm{R}_{1}=\mathrm{CH}_{3}, \mathrm{R}_{2}=\mathrm{O}, \mathrm{R}_{3}=\alpha$-L-arabinofuranosyl(1-2)- $\alpha$-Larabinopyranosyl $(1 \rightarrow 3)$ [rhamnopyranosyl $(1 \rightarrow 2)$ ]- $\beta$-D-glucopyranosyl $(1 \rightarrow 2)-\alpha$-L-arabinopyranosyl$(1 \rightarrow 6)$ - $\beta$-D-glucopyranoside

99 (23R) $R_{1}=C_{3} R_{2}=O, R_{3}=\beta$-D-glucopyranoyl- $(1 \rightarrow 2)$ - $\alpha$-L-arabinopyranosyl-(1 $\left.\rightarrow 6\right)-\beta-D$ glucopyranoside

100 (23S) $\mathrm{R}_{1}=\mathrm{CH}_{2} \mathrm{OH}, \mathrm{R}_{2}=2 \mathrm{H}, \mathrm{R}_{3}=\alpha$-L-arabinopyranosyl-(1 $\left.\rightarrow 2\right)-\beta$-D-galactopyranosyl-(1 $\left.\rightarrow 3\right)-$ $[\beta$-D-apiofuranosyl-( $1 \rightarrow 2)-\beta$-D-glucopyranoyl-( $1 \rightarrow 2)-\alpha$-L-arabinopyranosyl- $(1 \rightarrow 6)-\beta$-Dglucopyranoside

101 (23S) $\mathrm{R}_{1}=\mathrm{CH}_{2} \mathrm{OH}, \mathrm{R}_{2}=2 \mathrm{H}, \mathrm{R}_{3}=\beta$-D-glucopyranoside

$102(23 R) \mathrm{R}_{1}=\mathrm{CH}_{2} \mathrm{OH}, \mathrm{R}_{2}=2 \mathrm{H}, \mathrm{R}_{3}=\alpha$-L-arabinopyranosyl( $\left.1 \rightarrow 3\right)[\beta$-D-apio-D-furanosyl- $\left.(1 \rightarrow 2)]\right]-$ $\beta$-D-glucopyranosyl $(1 \rightarrow 2)-\alpha$-L-arabinopyranosyl- $(1 \rightarrow 6)$ - $\beta$-D-glucopyranoside $103(23 R) \mathrm{R}_{1}=\mathrm{CH}_{2} \mathrm{OH}, \mathrm{R}_{2}=2 \mathrm{H}, \mathrm{R}_{3}=\beta$-D-apio-D-furanosyl-(1 $\left.\left.\rightarrow 2\right)\right]-\beta$-D-glucopyranosyl $(1 \rightarrow 2)$ - $\alpha$ L-arabinopyranosyl-( $1 \rightarrow 6)-(\beta$-D-glucopyranoside 
<smiles>OC[C@H]1[C@@H](O)[C@@H](O)[C@@H]2CCCN21</smiles>

88<smiles></smiles>

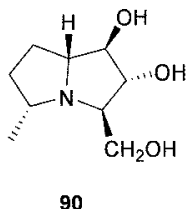

90

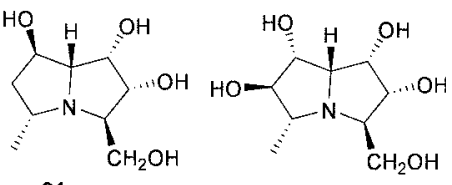

92

$93 \mathrm{R}_{1}=6-\mathrm{O}-(E)-p$-coumaroyl- $\beta$-D-glucopyranoside, $\mathrm{R}_{2}=6-\mathrm{O}$ malonyl-4-O-( $\alpha$-L-rhamnopyranosyl)- $\beta$-D-glucoside, $R_{3}=O H, R_{4}$ $=\mathrm{OH}$

$94 \mathrm{R}_{1}=\beta$-D-glucopyranoside, $\mathrm{R}_{2}=\mathrm{H}, \mathrm{R}_{3}=\mathrm{OH}, \mathrm{R}_{4}=\mathrm{OH}$

$95 \mathrm{R}_{1}=\beta$-D-glucopyranoside, $\mathrm{R}_{2}=\mathrm{H}, \mathrm{R}_{3}=\mathrm{OH}, \mathrm{R}_{4}=\mathrm{OMe}$

$96 \mathrm{R}_{1}=\beta$-D-glucopyranoside, $\mathrm{R}_{2}=\mathrm{H}, \mathrm{R}_{3}=\mathrm{OMe}_{1} \mathrm{R}_{4}=\mathrm{OMe}$

An aqueous ethanol extract of the bulbs of Ledebouria socialis (Baker) Jessop (as Scilla socialis Baker) was found to contain eleven hyacinthacines (108-118) as well as two pyrrolidines (119-120) and three piperidines (121-123). ${ }^{60}$ Hyacinthacines appear to be restricted to the Hyacinthoideae. These compounds have been found in Othocallis siberica (Haw.) Speta (as Scilla sibirica), Oncostema peruviana (L.) Speta (as Scilla peruviana), Hyacinthoides non-scripta (L.) Chouard ex Rothm., Hyacinthoides hispanica (Mill.) Rothm. (as Scilla campanulata), and Muscari armeniacum. The hyacinthacines are characterised as $7 \alpha$ - $R$-hydro-1,2-dihydroxy-3-hydroxymethylpyrrolizidines and in general appear to be weak to moderate inhibitors of glycosidases. ${ }^{60}$ The dichloromethane and methanol extracts of the bulbs of Ledebouria socialis have yielded five compounds, the scillascillin-type homoisoflavanones 124 and 125, phytol, stigmasterol and the polyhydroxylated difuran derivative, polybotrin 126. ${ }^{61}$ The different types of compounds isolated reflect the different solvents used for extraction, with the more polar extracts yielding the more polar polyhydroxy alkaloids and the less polar extracts the homoisoflavanones and sterols.
Early work by Gunn et $a .^{62}$ on some southern African Ledebouria species, examined the cardiac effect of Ledebouria cooperi (Hook.f.) Jessop (as Scilla cooperi Hook and as Scilla rogersii Baker) and Ledebouria ovatifolia (Baker) Jessop (as Scilla lanceaefolia Baker). Both species produced a similar action to digitalis when applied to isolated frog and cat hearts as well as in situ frog, cat and dog hearts. The extracts obtained were, however, insufficient in quantity to determine minimum lethal doses and the active components were not identified.

The chemical constituents of a further six southern African Ledebouria species have been investigated. Two samples of the bulbs of Ledebouria zebrina (Baker) S.Venter (as Scilla zebrina Baker), collected from two different regions in South Africa (Durban and Blyde River, Mpumalanga) have been investigated and the chemical differences noted. Both contained homoisoflavanones (Durban bulbs compounds $\mathbf{1 2 7}$ and $\mathbf{1 2 8}$ and the Blyde River bulbs compounds $127, \mathbf{1 2 9}, \mathbf{1 3 0}$ ). In addition to the homisoflavanones, the Blyde River bulbs also contained spirocyclic nortriterpenoids $(\mathbf{1 3 1}, \mathbf{2 1})$, while the Durban bulbs produced a chalcone $\mathbf{1 3 2 .}{ }^{63}$ The bulbs of Ledebouria cooperi

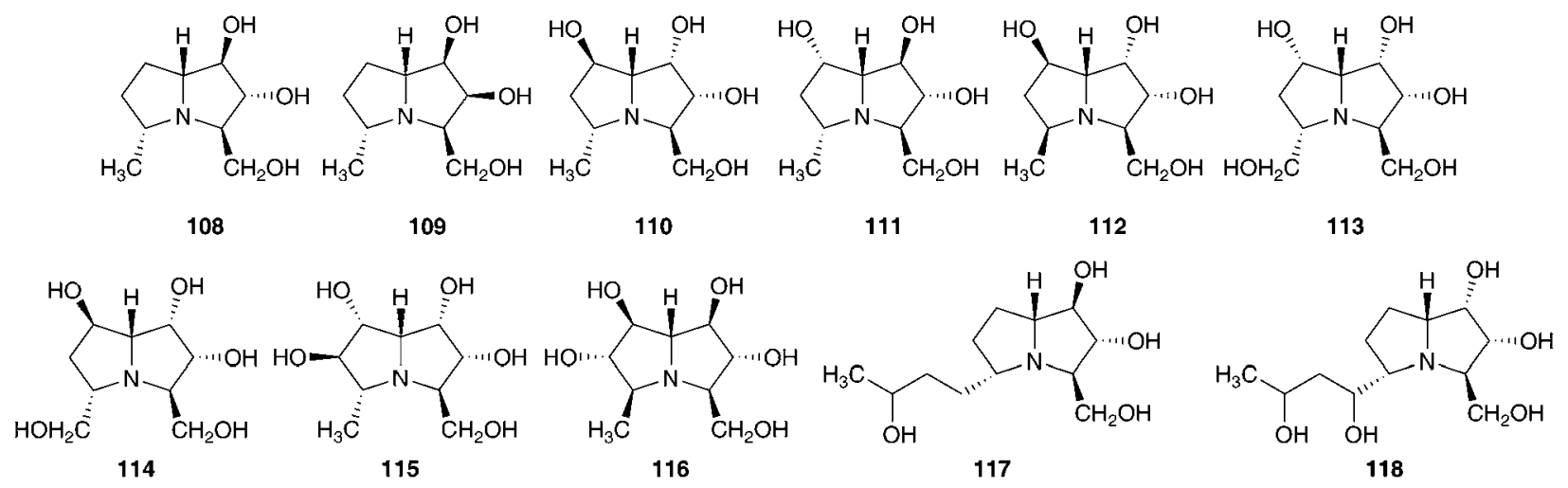


<smiles>CC[C@H]1N[C@H](CO)[C@@H](O)[C@H](O)[C@H]1O</smiles><smiles>[R6]c1cc([R])c2c(c1)OC([R5])[C@](C)(c1cc([R6])c([2H])c([R6])c1C)C2=O</smiles><smiles>O=C1O[C@H](O)C=C1[C@H]1O[C@H](CO)[C@@H](O)[C@H]1O</smiles>

$124 \mathrm{R}_{1}=\mathrm{OMe}, \mathrm{R}_{2}=\mathrm{OH}, \mathrm{R}_{3}=\mathrm{OMe}, \mathrm{R}_{4}=$

$125 \mathrm{R}_{1}=\mathrm{OMe}, \mathrm{R}_{2}=\mathrm{OH}, \mathrm{R}_{3}=\mathrm{OMe}, \mathrm{R}_{4}=$

$\mathrm{OMe}, \mathrm{R}_{5}=\mathrm{H}, \mathrm{R}_{6}=\mathrm{OH}$

$139 \mathrm{R}_{1}=\mathrm{OMe}, \mathrm{R}_{2}=\mathrm{OAc}, \mathrm{R}_{3}-\mathrm{R}_{4}=\mathrm{O}-\mathrm{CH}_{2}-\mathrm{O}$,

$\mathrm{R}_{5}=\beta-O A C, \mathrm{R}_{6}=\mathrm{H}$

$140 \mathrm{R}_{1}=\mathrm{OMe}, \mathrm{R}_{2}=\mathrm{OAC}, \mathrm{R}_{3}-\mathrm{R}_{4}=\mathrm{O}-\mathrm{CH}_{2}-\mathrm{O}$,

$\mathrm{R}_{5}=\alpha-\mathrm{OAC}, \mathbf{R}_{6}=\mathrm{H}$

$142 \mathrm{R}_{1}=\mathrm{OMe}, \mathrm{R}_{2}=\mathrm{OH}, \mathrm{R}_{3}-\mathrm{R}_{4}=\mathrm{O}-\mathrm{CH}_{2}-\mathrm{O}$.

$\mathrm{R}_{5}=\mathrm{H}, \mathrm{R}_{6}=\mathrm{H}$

$143 \mathrm{R}_{1}=\mathrm{OH}, \mathrm{R}_{2}=\mathrm{OH}, \mathrm{R}_{3}=\mathrm{OMe}, \mathrm{R}_{4}=\mathrm{OH}$,

$\mathrm{R}_{5}=\mathrm{H}, \mathrm{R}_{6}=\mathrm{H}$

$144 \mathrm{R}_{1}=\mathrm{OH}, \mathrm{R}_{2}=\mathrm{OH}, \mathrm{R}_{3}=\mathrm{OH}, \mathrm{R}_{4}=\mathrm{OMe}$

$\mathrm{R}_{5}=\mathrm{H}, \mathrm{R}_{6}=\mathrm{H}$

$160 \mathrm{R}_{1}=\mathrm{OH}, \mathrm{R}_{2}=\mathrm{OH}, \mathrm{R}_{3}=\mathrm{OMe}, \mathrm{R}_{4}=\mathrm{OMe}$,

$R_{5}=H, R_{6}=H$

$161 \mathrm{R}_{1}=\mathrm{OMe}, \mathrm{R}_{2}=\mathrm{OH}, \mathrm{R}_{3}=\mathrm{OMe}, \mathrm{R}_{\mathbf{4}}=$

$\mathrm{OMe}, \mathrm{R}_{5}=\mathrm{H}, \mathrm{R}_{6}=\mathrm{H}$

yielded the homoisoflavanones 59 and 62 as well as the eucosterol-type spirocyclic nortriterpenoid 133 and malic acid. Ledebouria ovatifolia bulbs were found to contain the chalcones 132 and 134 as well as the homoisoflavanone $30 .^{64,65}$ L. ovatifolia is used by the Zulu to treat gastro-enteritis, influenza and backache. In addition, it has been found to be toxic to sheep. ${ }^{66}$ Extracts of the bulbs were found to have good antibacterial activity against Gram-positive bacteria (MIC of $0.8-12.5 \mathrm{mg}$ $\mathrm{ml}^{-1}$ ), but poor anti-inflammatory and poor antihelmintic activity. ${ }^{\mathbf{6 6 , 6 7}} \mathrm{A}$ later investigation of the dichloromethane, ethyl acetate and methanol extracts of the bulbs led to the isolation of twenty-nine compounds, including xanthones (135-138), homoisoflavanones $(7, \mathbf{1 0}, 30,50,74,75,139-148)$, triterpenoids $(\mathbf{1 3 3}, \mathbf{1 4 9 - 1 5 0})$, chalcones $(\mathbf{1 3 2}, \mathbf{1 5 1})$ and simple aromatic compounds (152-154), including polybotrin $126 .{ }^{61,68}$ Sixteen of the above compounds isolated from $L$. ovatifolia were assessed for anti-inflammatory activity, in particular the selective inhibition of the COX-2 enzyme. Compounds 75, 137 and 146 were found to significantly inhibit COX-1 and COX-2 (percentage activity relative to the non-inhibitor control of $54-56 \%$ for COX-1 and 0\% for COX-2), while compound 145 showed good selectivity for the inhibition of COX-2 over COX-1 ( $\mathrm{IC}_{50}$ for COX-2 of $2.87 \mu \mathrm{M}$, with no statistically significant inhibition for COX-1 up to a concentration of $20 \mu \mathrm{M}) \cdot{ }^{61,68}$ During the same study, the norlignan hinokiresinol 155, previously isolated from Drimiopsis burkei Baker, ${ }^{69}$ was synthesised and tested for selective COX-2 inhibitory activity. Significant selective inhibition against COX-2 was observed (percentage activity relative to the non-inhibitor control of $93.8 \%$ for COX-1 and $0 \%$ for
COX-2). ${ }^{61,68}$ Ledebouria leptophylla (Baker) S.Venter (as Ledebouria graminifolia (Baker) Jessop), sourced in Botswana, is used traditionally to treat gastro-enteritis, backache and coughs as well as a treatment for skin irritations and for dressing wounds. A phytochemical investigation of the bulbs found seven 3-benzyl-4-chromanones (30, 62, 128, 156-159), two 3-benzyl-3-hydroxy-4-chromanones $(7,57)$, two scillascillintype homisoflavanones (160-161) and two xanthones (136 and 162). Cultivated and wild-sourced bulbs contained the same compounds. ${ }^{\mathbf{7 0}, 71}$ There was initial concern about the presence of the xanthones and speculation as to whether they may have come from a fungal or lichen contamination of the wild bulbs. The fact that the cultured bulbs contained the same xanthones confirmed that they were secondary metabolites of L. leptophylla. ${ }^{72}$

Within South Africa Ledebouria revoluta (L.f.) Jessop is extremely widespread. It is used by the Sotho to drive away lightening and with the exception of pregnant women, to treat lumbago. The Kwena and Tswana use it to treat wounds and skin conditions. The bulbs were found to contain homoisoflavanones $\left(30,59,61\right.$ and 157). ${ }^{73}$ Ledebouria floribunda (Baker) Jessop is used by traditional healers in the Eastern Cape of South Africa to treat skin disorders, tuberculosis, urinary tract infections and gastroenteritis. Three homoisoflavanones, with unusual substituents at C-6, -7 and -8 (163-165) have been isolated from the bulbs as well as two 7-O-diglycosides (166-167) and five additional homoisoflavanones $(\mathbf{1 0}, 30,50,62,168)$. These latter seven homoisoflavanones have shown good antioxidant activity against the DPPH radical $\left(\mathrm{IC}_{50}\right.$ of $31-273 \mu \mathrm{g} \mathrm{ml}{ }^{-1}$ ) and in the $\beta$-carotene/ 
<smiles>[R6]c1ccc(C[C@H]2COc3c([R])c([R])c([R5])c([R])c3C2=O)cc1[R5]</smiles>

$127 \mathrm{R}_{1}=\mathrm{H}, \mathrm{R}_{2}=\mathrm{OMe}, \mathrm{R}_{3}=\mathrm{OH}, \mathrm{R}_{4}=\mathrm{OMe}, \mathrm{R}_{5}=\mathrm{OMe}, \mathrm{R}_{6}=$

$\mathrm{OH}$

$128 \mathrm{R}_{1}=\mathrm{H}, \mathrm{R}_{2}=\mathrm{OMe}, \mathrm{R}_{3}=\mathrm{OH}, \mathrm{R}_{4}=\mathrm{OMe}, \mathrm{R}_{5}=\mathrm{H}, \mathrm{R}_{6}=\mathrm{OH}$

$129 R_{1}=H, R_{2}=O M e, R_{3}=O H, R_{4}=O H, R_{5}=O M e, R_{6}=O H$

$130 \mathrm{R}_{1}=\mathrm{H}, \mathrm{R}_{2}=\mathrm{OH}, \mathrm{R}_{3}=\mathrm{H}, \mathrm{R}_{4}=\mathrm{OH}, \mathrm{R}_{5}=\mathrm{OMe}, \mathrm{R}_{6}=\mathrm{OH}$

$141 \mathrm{R}_{1}=\mathrm{OMe}, \mathrm{R}_{2}=\mathrm{OH}, \mathrm{R}_{3}=\mathrm{H}, \mathrm{R}_{4}=\mathrm{OMe}, \mathrm{R}_{5}=\mathrm{H}, \mathrm{R}_{6}=\mathrm{OH}$

$148 R_{1}=H, R_{2}=O H, R_{3}=H, R_{4}=O M e, R_{5}=O M e, R_{6}=O A C$

$156 \mathrm{R}_{1}=\mathrm{H}, \mathrm{R}_{2}=\mathrm{OMe}, \mathrm{R}_{3}=\mathrm{H}, \mathrm{R}_{4}=\mathrm{OH}, \mathrm{R}_{5}=\mathrm{H}, \mathrm{R}_{6}=\mathrm{OH}$

$157 \mathrm{R}_{1}=\mathrm{H}, \mathrm{R}_{2}=\mathrm{OH}, \mathrm{R}_{3}=\mathrm{H}, \mathrm{R}_{4}=\mathrm{OH}, \mathrm{R}_{5}=\mathrm{H}, \mathrm{R}_{6}=\mathrm{OMe}$

$158 R_{1}=H, R_{2}=O M e, R_{3}=O M e, R_{4}=O H, R_{5}=H, R_{6}=O H$

$159 \mathrm{R}_{1}=\mathrm{H}, \mathrm{R}_{2}=\mathrm{OH}, \mathrm{R}_{3}=\mathrm{H}, \mathrm{R}_{4}=\mathrm{OH}, \mathrm{R}_{5}=\mathrm{OH}, \mathbf{R}_{6}=\mathrm{OH}$

$166 R_{1}=H, R_{2}=0$-[ $\alpha$-L-rhamnopyranosyl- $(1 \rightarrow 6)-\beta$-D-

glucopyranoside], $\mathrm{R}_{3}=\mathrm{H}, \mathrm{R}_{4}=\mathrm{OH}, \mathrm{R}_{5}=\mathrm{H}, \mathrm{R}_{6}=\mathrm{OMe}$

$167 R_{1}=H, R_{2}=O$-[ $\alpha$-L-rhamnopyranosyl-(1 $\left.\rightarrow 6\right)-\beta$-D-

glucopyranoside], $\mathrm{R}_{3}=\mathrm{H}, \mathrm{R}_{4}=\mathrm{OH}, \mathrm{R}_{5}=\mathrm{H}, \mathrm{R}_{6}=\mathrm{OH}$

$168 \mathrm{R}_{1}=\mathrm{H}, \mathrm{R}_{2}=\mathrm{OH}, \mathrm{R}_{3}=\mathrm{OMe}, \mathrm{R}_{4}=\mathrm{OH}, \mathrm{R}_{5}=\mathrm{H}, \mathrm{R}_{6}=\mathrm{OH}$

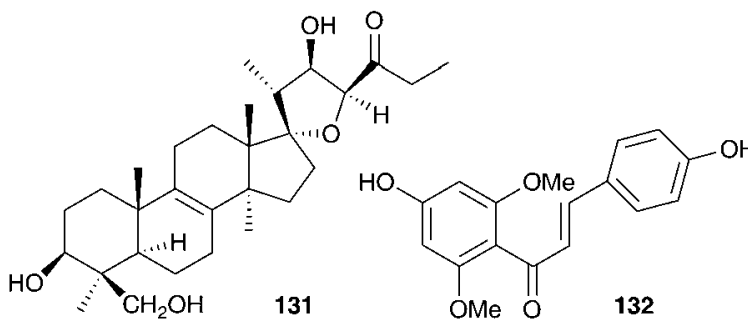

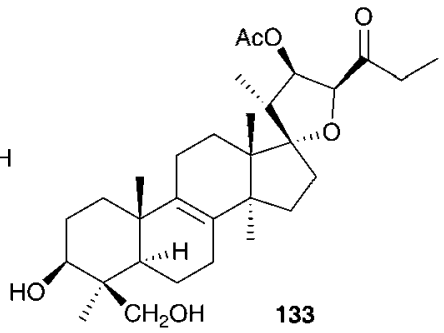<smiles>COc1ccc(/C=C/Cc2c(O)cc(OC)c(C(=O)/C=C/c3ccc(O)cc3)c2OC)cc1OC</smiles><smiles>[R]c1c([R3])c(O)c2c(=O)c3c(C)cc(O)c([R])c3oc2c1[R]</smiles><smiles>COc1cc(O)c2c(=O)c3c([N+](=O)[O-])cc(O)cc3oc2c1</smiles>

134

$135 \mathrm{R}_{1}=\mathrm{OMe}, \mathrm{R}_{2}=\mathrm{H}, \mathrm{R}_{3}=\mathrm{OMe}, \mathrm{R}_{4}=\mathrm{OMe}$

$137 \mathrm{R}_{1}=\mathrm{H}, \mathrm{R}_{2}=\mathrm{H}, \mathrm{R}_{3}=\mathrm{OH}, \mathrm{R}_{4}=\mathrm{OMe}$

$138 R_{1}=H, R_{2}=H, R_{3}=O H, R_{4}=H$

$162 \mathrm{R}_{1}=\mathrm{H}, \mathrm{R}_{2}=\mathrm{OMe}, \mathrm{R}_{3}=\mathrm{OH}, \mathrm{R}_{4}=\mathrm{OMe}$<smiles>[R]c1cc([R2])c2c(c1)OC/C(=C\c1ccc([R6])c([R5])c1)C2=O</smiles>

$145 \mathrm{R}_{1}=\mathrm{OH}, \mathrm{R}_{2}=\mathrm{OMe}, \mathrm{R}_{3}=\mathrm{OH}, \mathrm{R}_{4}=\mathrm{OH}$ $146 R_{1}=\mathrm{OH}, \mathrm{R}_{2}=\mathrm{OH}, \mathrm{R}_{3}=\mathrm{OH}, \mathrm{R}_{4}=\mathrm{OH}$ $147 R_{1}=O A c, R_{2}=O M e, R_{3}=H, R_{4}=O A c$

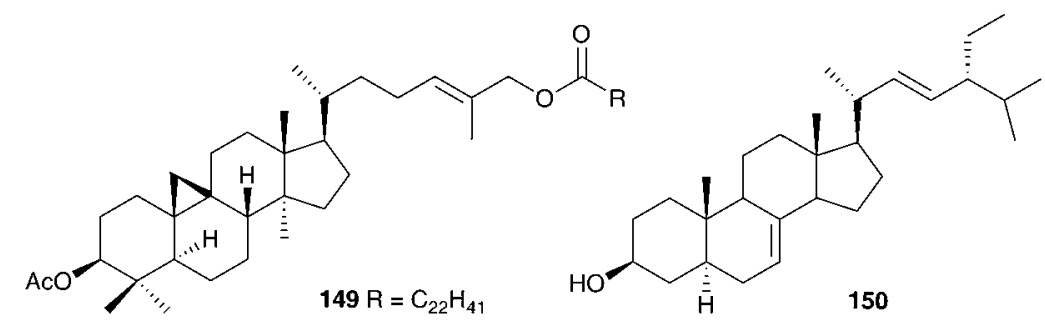<smiles>COc1cc(O)cc(OC)c1C(=O)CCc1ccc(O)cc1</smiles>
151<smiles>COc1ccc(C=O)cc1/C=C/C=O</smiles><smiles>C=C[C@@H](/C=C\c1ccc(O)cc1)c1ccc(O)cc1</smiles> 
linoleic acid system (antioxidant activity of up to 79\% after 120 min) as did 164 and 165 against the $\mathrm{DPPH}$ radical $\left(\mathrm{IC}_{50}\right.$ of 23.2 and $28.7 \mu \mathrm{g} \mathrm{ml}^{-1}$ respectively)..$^{74,75}$

Leopoldia comosa (L.) Parl. is found largely in the Mediterranean region and the bulbs have been used as a food source for generations. ${ }^{76}$ Evidence for the ancient use of this plant includes the discovery of traces of this species in a Neanderthal grave in Iraq. ${ }^{77}$ The bulbs (as Muscari comosum Mill.) were examined for antioxidant activity as part of a study on noncultivated vegetables commonly consumed by Albanians living in southern Italy. Twenty-seven plant species were investigated, with two showing high activity, one of which was $L$. comosa (inhibitory activity on a DPPH assay of $85 \%$ ). ${ }^{78}$ A further study also found good antioxidant activity as well as hypoglycemic activity via the inhibition of carbohydrate digestive enzymes. ${ }^{79}$ Extracts of L. comosa (as Muscari comosum Mill.) have been found to be effective in combatting the wood rot fungus Postia placenta in samples of Pinus sylvestris L. and Fagus orientalis. ${ }^{80}$ Phytochemical studies on L. comosa (as Muscari comosum Mill.) have resulted in the isolation of nineteen nortriterpenoids of the lanosterol-type as well as homoisoflavanones.

Initial work on the bulbs was complicated by the presence of complex glycosides. Acid catalysed methanolysis of the glycoside mixture resulted in the identification of the aglycones. Eucosterol 20 was found to be the major component, with compounds 21, 54, 169, 170 and 171 present in smaller amounts. ${ }^{7,81-84}$ Extensive work on the bulbs by Adinolfi et al. resulted in the isolation of the free aglycones present in the bulbs $(\mathbf{2 0}, \mathbf{2 1}, \mathbf{2 2}, \mathbf{5 4}, \mathbf{1 6 9 - 1 7 5})^{\mathbf{8 5 - 8 9}}$ as well as the full structural elucidation of the glycosides $\left(86,87,102,103\right.$ and 176) ${ }^{90-94}$ All the nortriterpenes isolated from Leopoldia comosa mentioned so far have $S$ configuration at C-23, three compounds with $R$ configuration have also been identified, 177, ${ }^{91} 178$ (23R 20) and 179 (23R 170). ${ }^{89}$

Two classes of homoisoflavanones have been isolated from the bulbs of $L$. comosa, the 3-benzyl-4-chromones $(\mathbf{3 0}, \mathbf{5 8}, \mathbf{5 9}, \mathbf{6 1}$, 62, 80, 97, 180-181 $)^{95,96}$ and the scillascillin type $(55,104-107$ and 182). ${ }^{97,98}$ The absolute configuration at C-3 of these<smiles>COc1ccc(CC2COc3cc4c(c(O)c3C2=O)C=CC(C)(C)O4)cc1</smiles>

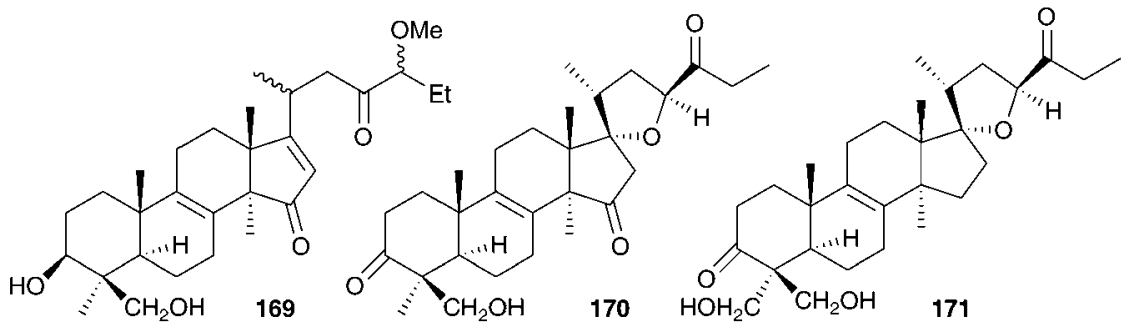

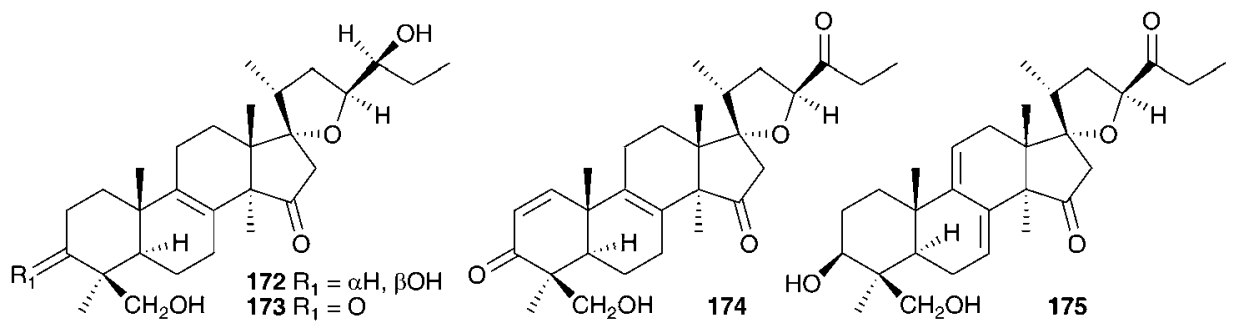




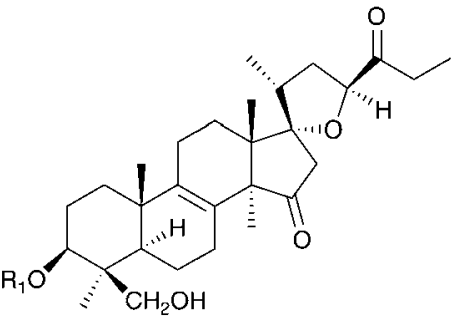

$176 \mathrm{R}_{1}=\beta$-D-apio-D-furanosyl- $\left.(1 \rightarrow 2)\right]-\beta$-Dglucopyranosyl( $1 \rightarrow 2)-\alpha$-L-arabinopyranosyl- $(1 \rightarrow 6)-\beta$-Dglucopyranoside

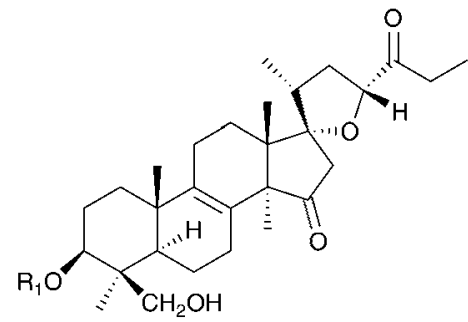

$177 R_{1}=\alpha$-L-arabinofuranosyl $(1 \rightarrow 2)-\alpha-L-$ arabinopyranosyl $(1 \rightarrow 3)[\alpha-L$-rhamnopyranosyl $(1 \rightarrow 2)]-\beta-D$ glucopyranosyl $(1 \rightarrow 2)-\alpha$-L-arabinopyranosyl $(1 \rightarrow 6)-\beta-D-$ glucopyranoside $178 \mathrm{R}_{1}=\mathrm{H}$ homoisoflavanones was determined using circular dichroism and found to be $R$ in all cases. ${ }^{99}$ For the scillascillin type, this was further confirmed by X-ray analysis..$^{98}$ The crude extract of the bulbs has been subjected to anti-inflammatory bioassaydirected fractionation using a croton oil-induced mouse ear dermatitis test. The homoisoflavanone rich fraction was found to have high activity and further fractionation resulted in the isolation of 30, 59, 61, 80 and 97 , all of which showed activity, with compound 30 being the most active at $41 \%$ inhibition (100 $\mu \mathrm{g}$ ear $\left.^{-1}\right) .{ }^{100}$ Two flavonoids have been isolated from the flowers of $L$. comosa, 3-glucoarabinosyl- and 3-rhamnoarabinosyl-3,4,5trihydroxy-7-alkoxyl flavone. ${ }^{101}$

Leopoldia comosa is used in the Basilicata region of southern Italy to treat toothache and headache. ${ }^{102}$ One third of the plants used for medicinal purposes in southern Italy are used to treat skin and soft tissue infections. As Staphylococcus aureus is a common cause of such infections, the effect of a number of Italian plants, including the bulbs of Leopoldia comosa, on the inhibition of the S. aureus biofilms has been studied. Significant dose-dependent biofilm inhibition $\left(\mathrm{IC}_{50}=16 \mu \mathrm{g} \mathrm{ml} \mathrm{m}^{-1}\right)$ was noted for $L$. comosa. ${ }^{103}$

Investigations into the chemistry of the bulbs of Scilla luciliae (Boiss.) Speta (as Chionodoxa gigantea Whittall and as Choinodoxa luciliae Boiss.) has yielded a large number of lanosterol-type spirocyclic nortriterpenoids, many of which have been tested for biological activity. Compounds 183-186 16,104 $^{1}$

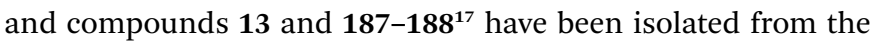
bulbs of Scilla luciliae (as Chionodoxa gigantea). In separate investigations, compounds 13,184 and $187-190^{17}$ as well as compounds 189 and 190-197 and eucosterol 20, ${ }^{105}$ compounds 198-204, ${ }^{106} 205-207^{107}$ and $208-209^{108}$ have been found in the bulbs of this species (as C. luciliae). Compounds 183-186 all showed some inhibitory activity on cyclic AMP phosphodiesterase, with compound 183 giving the best results $\left(\mathrm{IC}_{50}=11.2\right.$ $\left.\times 10^{-5} \mathrm{M}\right){ }^{104}$ Cytotoxicity against HeLa cells was assessed for $13,184,187,188,189$, and 190 with the 15-deoxoeucosterol oligosaccharides $(13,187$ and 190) showing good activity down to $5 \mu \mathrm{g} \mathrm{ml}{ }^{-1} \cdot{ }^{17}$ Compounds $198-204$ as well as 183 and 185 were tested for activity against HSC-2 human oral squamous carcinoma cells. Compounds 183, 185, 200, 201 and 204 all gave good results with $\mathrm{LD}_{50}$ values in the range 10-23 $\mu \mathrm{g} \mathrm{ml}^{-1}$ (etoposide $\mathrm{LD}_{50}=24 \mu \mathrm{g} \mathrm{ml}{ }^{-1}$, for etoposide resistant HSC cells). It was noted that the $23 R$ isomer of $\mathbf{1 8 5}$, compound 186 did not show any activity. ${ }^{106}$ Compounds 208 and 209 showed only weak activity in the same assay ( $\mathrm{LD}_{50}$ of 254 and $238 \mu \mathrm{g}$ $\mathrm{ml}^{-1}$ respectively). ${ }^{108}$ In addition to the spirocyclic nortriterpenoids, the bulbs of Scilla luciliae (as Chionodoxa luciliae) have been found to contain the homoisoflavanones 210222. 109

The bulbs and aerial parts of Scilla bifolia L. have been studied using HPLC and mass spectrometry. Eighteen polyphenols were identified from extracts of the bulbs and aerial parts (caftaric acid, isoquercitin, routine, myricetol, fistein, quercetol, patuletin, gentisic acid, caffeic acid, chlorogenic acid, $p$-coumaric acid, ferulic acid, hyperoside, quercitrin, luteolin, kaempferol, apigenin and sinapic acid). ${ }^{110}$

The methanol and aqueous ethanol extracts of the bulbs of Autonoe madeirensis (Menezes) Speta (as Scilla maderensis Menezes), a species endemic to the Portuguese archipelago of Madeira, was found to produce cardiac action on a frog heart and although TLC showed compounds with $\mathrm{R}_{\mathrm{f}}$ values and colours very similar to the bufadienolides proscillaridin A $\mathbf{2 2 3}$ and scillaren A 224, typical of the Urgineoideae, the presence of these compounds was not conclusively established. ${ }^{111}$<smiles>COc1cc([C@H]2COc3cc(O)cc(O)c3C2=O)cc(O)c1OCc1ccc(O)cc1</smiles> 


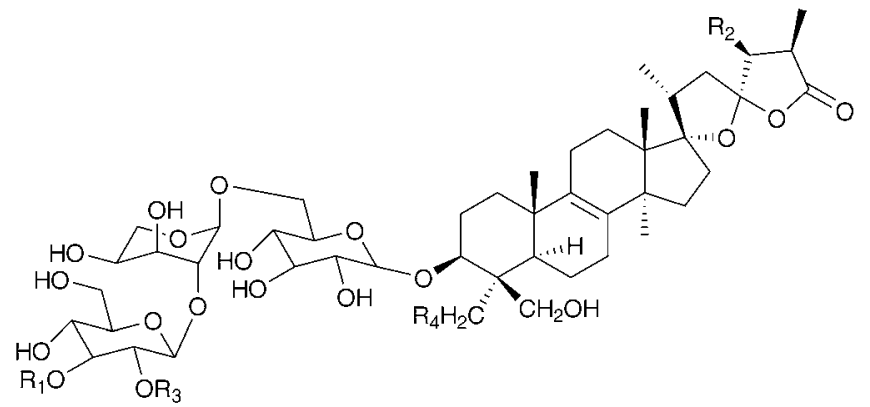

$183 R_{1}=\beta$-D-glucopyranosyl( $\left.1 \rightarrow 2\right)-\beta$-D-glucopyranosyl, $R_{2}=H, R_{3}=\alpha$-Lrhamnopyranosyl, $\mathrm{R}_{4}=\mathrm{H}$

$184 R_{1}=H, R_{2}=O H, R_{3}=\alpha$-L-rhamnopyranosyl, $R_{4}=H$

$203 \mathrm{R}_{1}=\mathrm{H}, \mathrm{R}_{2}=\mathrm{H}, \mathrm{R}_{3}=\beta$-D-apiofuranosyl, $\mathrm{R}_{4}=\mathrm{OH}$

$204 R_{1}=\beta$-D-glucopyranosyl, $R_{2}=H, R_{3}=\alpha$-L-rhamnopyranosyl, $R_{4}=H$

$205 R_{1}=H, R_{2}=H, R_{3}=\alpha$-L-rhamnopyranosyl, $R_{4}=H$

$206 R_{1}=(1 \rightarrow 3)-\beta$-D-galactopyranosyl, $R_{2}=H, R_{3}=\alpha$-L-rhamnopyranosyl, $R_{4}$

$=\mathrm{H}$

$207 R_{1}=\beta$-D-glucopyranosyl $(1 \rightarrow 2)-\beta$-D-galactopyranosyl, $R_{2}=O H, R_{3}=\alpha$-Lrhamnopyranosyl, $\mathrm{R}_{4}=\mathrm{H}$

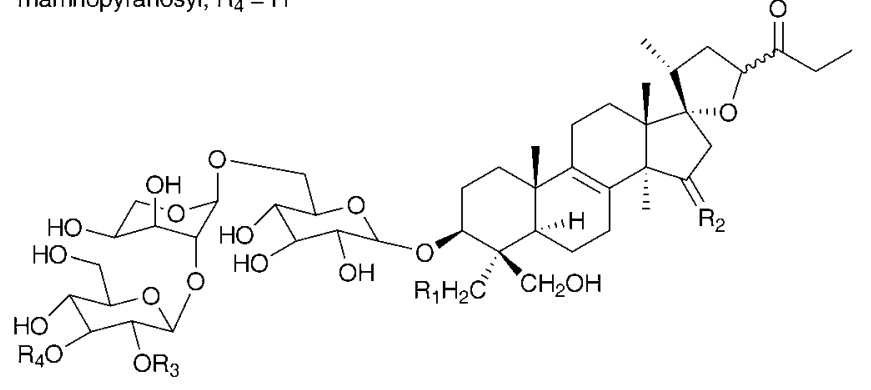

185 (23 S) $R_{1}=H, R_{2}=H, R_{3}=\alpha$-L-rhamnopyranosyl, $R_{4}=-(1 \rightarrow 2)$-O- $\beta$-D-glucopyranosyl-(1 $\left.\rightarrow 3\right)$-O- $\beta$-D-glucopyranosyl 186 (23R) $R_{1}=H, R_{2}=H, R_{3}=\alpha$-L-rhamnopyranosyl, $R_{4}=-(1 \rightarrow 2)$-O- $\beta$-D-glucopyranosyl-(1 $\left.\rightarrow 3\right)$-O- $\beta$-D-glucopyranosyl $189\left(23\right.$ S) $R_{1}=H, R_{2}=H, H, R_{3}=\alpha$-L-rhamnopyranosyl, $R_{4}=H$

190 (23 S) $R_{1}=H, R_{2}=H, H, R_{3}=\alpha$-L-rhamnopyranosyl, $R_{4}=\beta$-D-glucopyranosyl $(1 \rightarrow 2)$ - $\beta$-D-glucopyranosyl

$191\left(23\right.$ S) $R_{1}=H, R_{2}=H, H, R_{3}=\alpha$-L-rhamnopyranosyl, $R_{4}=\beta$-D-glucopyranosyl $(1 \rightarrow 2)-\beta$-D-galactopyranosyl

$192\left(23\right.$ S) $R_{1}=H, R_{2}=H, H, R_{3}=\alpha$-L-rhamnopyranosyl, $R_{4}=\beta$-D-glucopyranosyl $(1 \rightarrow 2)-\alpha$-L-arabinopyranosyl

193 (23 S) $\mathrm{R}_{1}=\mathrm{OH}, \mathrm{R}_{2}=\mathrm{H}, \mathrm{H}, \mathrm{R}_{3}=\alpha$-L-rhamnopyranosyl, $\mathrm{R}_{4}=\beta$-D-glucopyranosyl( $\left.1 \rightarrow 2\right)-\beta$-D-galactopyranosyl

194 (23 S) $R_{1}=O H, R_{2}=H, H, R_{3}=\alpha$-L-arabinofuranosy, $R_{4}=-\beta$-D-galactopyranosyl

195 (23 S) $R_{1}=\mathrm{OH}, \mathrm{R}_{2}=\mathrm{H}, \mathrm{H}, \mathrm{R}_{3}=\beta$-D-apiofuranosyl, $\mathrm{R}_{4}=\beta$-D-glucopyranosyl( $\left.1 \rightarrow 2\right)$ - $\beta$-D-galactopyranosyl

196 (23 S) $\mathrm{R}_{1}=\mathrm{OH}, \mathrm{R}_{2}=\mathrm{H}, \mathrm{H}, \mathrm{R}_{3}=\alpha$-L-rhamnopyranosyl, $\mathrm{R}_{4}=\mathrm{H}$

197 (23 S) $\mathrm{R}_{1}=\mathrm{OH}, \mathrm{R}_{2}=\mathrm{O}, \mathrm{R}_{3}=\alpha$-L-rhamnopyranosyl, $\mathrm{R}_{4}=\mathrm{H}$

198 (23 S) $R_{1}=O H, R_{2}=H, H, R_{3}=\beta$-D-apiofuranosyl, $R_{4}=H$

199 (23 S) $R_{1}=O H, R_{2}=H, H, R_{3}=\beta$-D-apiofuranosyl, $R_{4}=\beta$-D-glucopyranosyl

200 (23 S) $R_{1}=O H, R_{2}=H, R_{3}=\alpha$-L-rhamnopyranosyl, $R_{4}=H$

201 (23 S) $R_{1}=H, R_{2}=H, R_{3}=\alpha$-L-rhamnopyranosyl, $R_{4}=-(1 \rightarrow 2)-\beta$-D-glucopyranosyl

202 (23 S) $R_{1}=H, R_{2}=O, R_{3}=\alpha$-L-rhamnopyranosyl, $R_{4}=-(1 \rightarrow 2)-\beta$-D-glucopyranosyl-(1 $\left.\rightarrow 3\right)-\beta$-D-glucopyranosyl

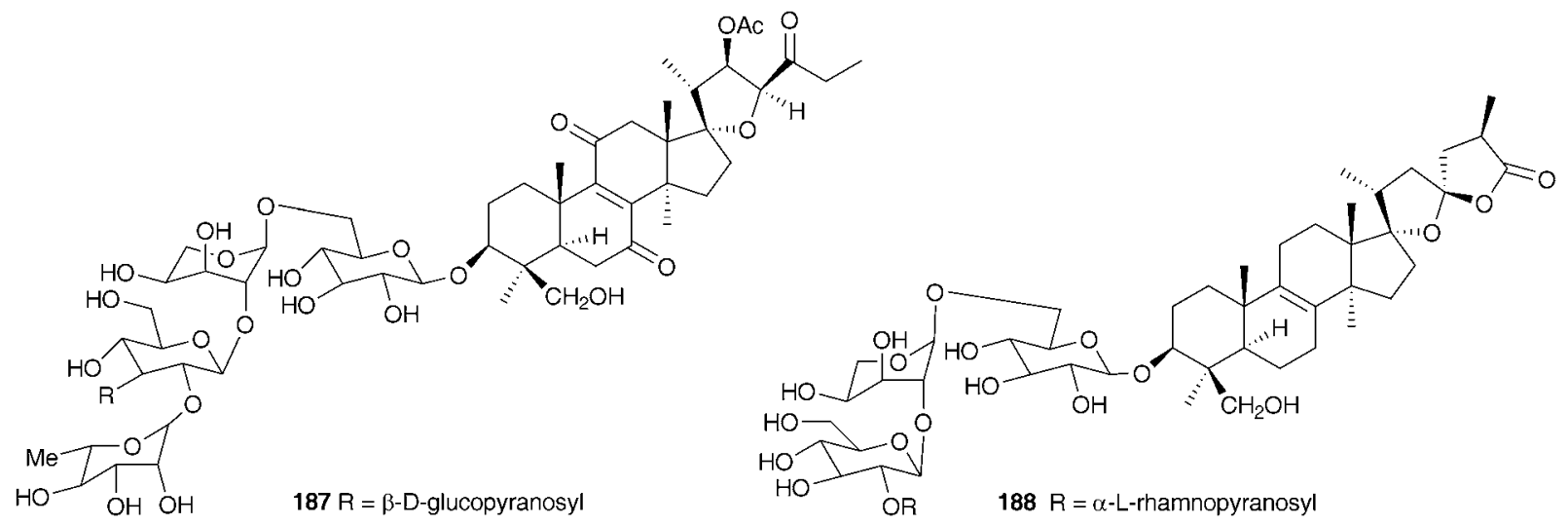




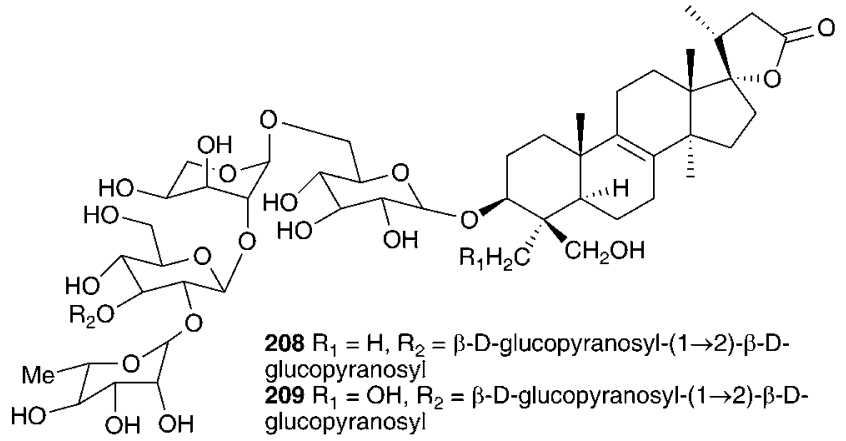<smiles>[R6]c1ccc(C[C@H]2COc3c([R])c(O)c([R2])c(O)c3C2=O)cc1[R5]</smiles>

$210 \mathrm{R}_{1}=\mathrm{OMe}, \mathrm{R}_{2}=\mathrm{H}, \mathrm{R}_{3}=\mathrm{OH}, \mathrm{R}_{4}=\mathrm{OMe}$ $211 \mathrm{R}_{1}=\mathrm{H}, \mathrm{R}_{2}=\mathrm{OMe}, \mathrm{R}_{3}=\mathrm{OH}, \mathrm{R}_{4}=\mathrm{OMe}$ $212 \mathrm{R}_{1}=\mathrm{OMe}, \mathrm{R}_{2}=\mathrm{H}, \mathrm{R}_{3}=\mathrm{H}, \mathrm{R}_{4}=\mathrm{OH}$ $213 \mathrm{R}_{1}=\mathrm{H}, \mathrm{R}_{2}=\mathrm{H}, \mathrm{R}_{3}=\mathrm{OH}, \mathrm{R}_{4}=\mathrm{OMe}$ $214 R_{1}=H, R_{2}=O M e, R_{3}=H, R_{4}=O H$ $215 R_{1}=H, R_{2}=H, R_{3}=O H, R_{4}=O H$<smiles>[R]c1cc(/C=C2\COc3c([R])c(O)c([R6])c(O)c3C2=O)ccc1O</smiles><smiles>[R]c1cc(O)c2c(c1)OC([R6])[C@](C)(c1cc([2H])c([R2])cc1[R6])C2=O</smiles>

$216 \mathrm{R}_{1}=\mathrm{OMe} \mathrm{R}_{2}=\mathrm{H}, \mathrm{R}_{3}=\mathrm{OH}$ $217 \mathrm{R}_{1}=\mathrm{HR}_{2}=\mathrm{OMe}, \mathrm{R}_{3}=\mathrm{OH}$ $218 \mathrm{R}_{1}=\mathrm{OMe} \mathrm{R} \mathrm{R}_{2}=\mathrm{H}, \mathrm{R}_{3}=\mathrm{H}$

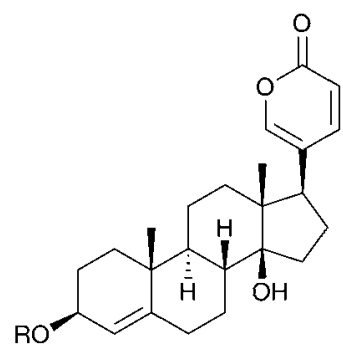

$223: R_{1}=\alpha$-L-rhamnopyranoside $224 \mathrm{R}_{1}=\alpha$-L-rhamnopyranosyl- $(1 \rightarrow 4)-\beta$-D glucopyranoside

Barnardia japonica (Thunb.) Schult. \& Schult.f. (as Scilla scilloides (Lind.) Druce) has been used for a long time by traditional Chinese healers to treat abscesses and to promote circulation. ${ }^{\mathbf{1 1 2}}$ This plant also grows extensively in the wild in Japan and Korea and has been used by traditional healers of the latter country. ${ }^{\mathbf{1 1 3}}$ The root extract has been evaluated for its potential as an antimicrobial agent, as an anti-inflammatory and as an antioxidant. ${ }^{113}$ The root extract of B. japonica (as Scilla scilloides) was found to inhibit the growth of Staphylococcus aureus, Salmonella enteritidis, Escherichia coli and Candida parapsilosis down to a concentration of $0.1 \%$ of the extract. Antioxidant activity was evaluated by looking at the inhibition of hyaluronidase, an enzyme that initiates the degradation of hyaluronic acid, associated with inflammation. Inhibition was noted at concentrations of root extract of 0.1 (14.8\% inhibition) and 1\% (48.2\% inhibition), but not below. Anti-oxidant activity was assessed by monitoring the oxidation of linoleic acid and good activity was found (anti-oxidative index of 33.2 at a concentration of $1 \%$ ). ${ }^{113}$ Extensive phytochemical investigations of the bulbs of B. japonica (as Scilla scilloides) resulted in the isolation of spirocyclic nortriterpenes $\left(\mathbf{2 1}, \mathbf{2 2}, \mathbf{1 3 1}, \mathbf{2 2 5}, 226\right.$ and 227), ${ }^{114,115}$ the related oligoglycosides (187, 228-239 and 241-247) ${ }^{112,116-118}$ and homoisoflavanones $\left(\mathbf{4 2}, 55\right.$ and 248) ${ }^{119}$ Nishida et al. ${ }^{120}$ reported the isolation of sixteen compounds from the methanol extract of the bulbs, including three nortriterpenes (21, 22, and 225), a lignan 249, a xanthone 137, two homostilbenes (250 and 251) and nine homoisoflavanones $(49,55, \mathrm{C}-3$ epimer compound of 62,182 , 252, 253, and 254-156). The configuration at C-3 for 253, 254 and the epimer of compound $\mathbf{6 2}$ was unusually found to be $S$ by circular dichroism. ${ }^{120}$ Scillascilloside E-3 239 and scillascilloside E-1 237 have shown potent cytotoxicity against a range of human cancer cells ( $\mathrm{ED}_{50}$ 1.5-3.0 $\mathrm{nM}$ and 1.6-5.9 $\mathrm{nM}$ respectively). ${ }^{112,117}$ Patents have been filed covering the use of B. japonica (as Scilla scilloides) bulb extracts for the treatment of fungal infections ${ }^{\mathbf{1 2 1}}$ and as a treatment for cancer. ${ }^{\mathbf{1 2 2}}$ A later investigation into the methanol extract of the bulbs resulted in the isolation of two norlanostane-type triterpenoid glycosides (257 and 258), a phenylpropanoid glycoside 259 and two alkaloids (260 and 261). ${ }^{123}$ The aqueous methanol extract of the bulbs of B. japonica (as Scilla japonica) produced some cardiac action on an isolated toad heart muscle, although the active components responsible were not identified. ${ }^{\mathbf{1 2 4}}$

Othocallis siberica (as Scilla sibirica Haw.) is native to southwestern Russia, the Caucasus and Turkey. The bulbs were found to contain $0.04 \%$ glycosides and $0.15 \%$ alkaloids, with the alkaloid fraction being able to stop the function of an isolated frog heart. The glycoside fraction showed a strong hypertensive action and was a stimulant to respiration. ${ }^{125}$ The hot water extract of the bulbs produced an acylated glucomannan with $\mathrm{D}^{-}$ mannose, D-glucose and an acyl group in a ratio of $7.7: 1: 2.4 .^{126}$ As part of their investigations into potential glycosidase inhibitors, Yamashita et al. examined the ethanol extract of the bulbs of $O$. siberica (as Scilla sibirica). They isolated 


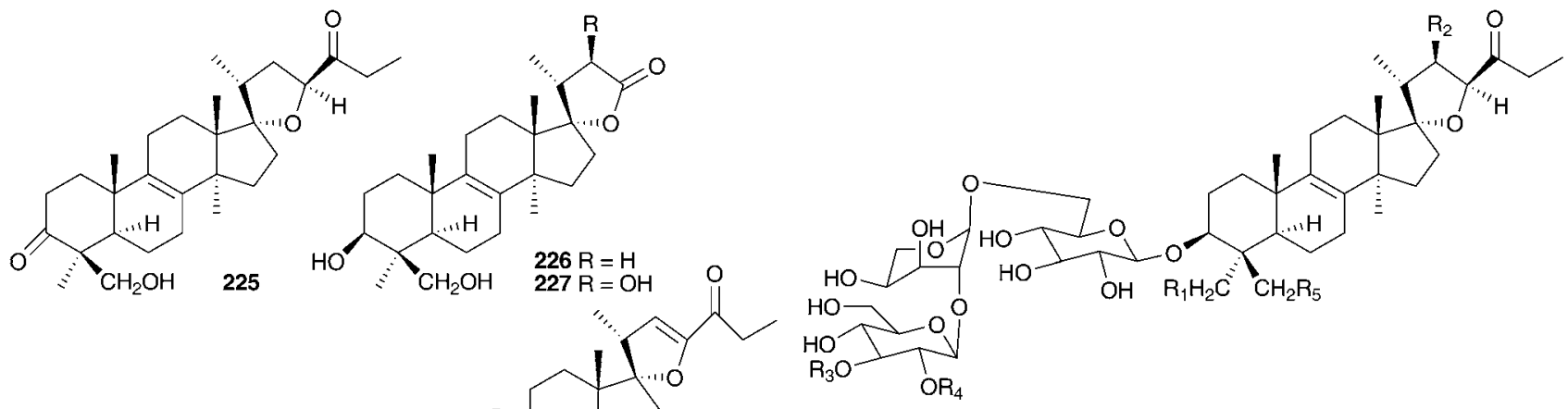

$228 \mathrm{R}_{1}=\mathrm{R}_{2}=\mathrm{R}_{4}=\mathrm{H}, \mathrm{R}_{3}=\alpha$-L-rhamnopyranosyl, $\mathrm{R}_{5}=\mathrm{OH}, \mathrm{R}_{6}=\mathrm{H}$

$229 R_{1}=R_{2}=H, R_{3}=\alpha$-L-rhamnopyranosyl, $R_{4}=\beta$-D-glucopyranosyl, $R_{5}=O H$, $\mathrm{R}_{6}=\mathrm{H}$

$230 R_{1}=R_{2}=H, R_{3}=\alpha$-L-rhamnopyranosyl, $R_{4}=\beta$-D-glucopyranosyl- $(1 \rightarrow 3)-\beta$-Dgalactopyranosyl- $(1 \rightarrow 3)-\beta$-D-glucopyranosyl, $R_{5}=O H, R_{6}=H$

$231 \mathrm{R}_{1}=\mathrm{OH}, \mathrm{R}_{2}=\mathrm{H}, \mathrm{R}_{3}=\alpha$-L-arapinofuranosyl, $\mathrm{R}_{4}=\beta$-D-glucopyranosyl, $\mathrm{R}_{5}=$ $\mathrm{OH}, \mathrm{R}_{6}=\mathrm{H}$

$232 \mathrm{R}_{1}=\mathrm{H}, \mathrm{R}_{2}=\mathrm{OAc}, \mathrm{R}_{3}=\alpha$-L-rhamnopyranosyl, $\mathrm{R}_{4}=\beta$-D-glucopyranosyl, $\mathrm{R}_{5}=$ $\mathrm{OH}, \mathrm{R}_{6}=\mathrm{H}$

$233 R_{1}=H, R_{2}=O A c, R_{3}=\alpha$-L-arapinofuranosyl, $R_{4}=\beta$-D-glucopyranosyl, $R_{5}=$ $\mathrm{OH}, \mathrm{R}_{6}=\mathrm{H}$

$235 \mathrm{R}_{1}=\mathrm{OH}, \mathrm{R}_{2}=\mathrm{H}, \mathrm{R}_{5}=\mathrm{OH}, \mathrm{R}_{3}=\alpha$-L-rhamnopyranosyl, $\mathrm{R}_{4}=\beta$-D-

glucopyranosyl, $R_{6}=H$

$237 \mathrm{R}_{1}=\mathrm{H}, \mathrm{R}_{2}=\mathrm{H}, \mathrm{R}_{5}=\mathrm{H}, \mathrm{R}_{3}=\alpha$-L-rhamnopyranosyl, $\mathrm{R}_{4}=\beta$-D-glucopyranosyl, $\mathrm{R}_{6}=\mathrm{H}$

$238 \mathrm{R}_{1}=\mathrm{OH}, \mathrm{R}_{5}=\mathrm{H}, \mathrm{R}_{3}=\alpha$-L-arabinofuranosyl $\mathrm{R}_{4}=\beta$-D-glucopyranosyl, $\mathrm{R}_{6}=\mathrm{H}$ $239 R_{1}=H, R_{2}=H, R_{5}=O A c, R_{3}=\alpha$-L-rhamnopyranosyl, $R_{4}=\beta$-Dglucopyranosyl, $\mathrm{R}_{6}=\mathrm{H}$

$240 \mathrm{R}_{1}=\mathrm{H}, \mathrm{R}_{2}=\mathrm{H}, \mathrm{R}_{5}=\mathrm{H}, \mathrm{R}_{3}=\alpha$-L-rhamnopyranosyl, $\mathrm{R}_{4}=\beta$-D-glucopyranosyl$(1 \rightarrow 3)$ - $\beta$-D-galactopyranosyl-(1 $\rightarrow 3$ )- $\beta$-D-glucopyranosyl, $R_{6}=H$

$257 \mathbf{R}_{1}=\mathbf{R}_{2}=\mathrm{H}, \mathbf{R}_{3}=\beta$-D-galactopyranosyl- $(1 \rightarrow 3)-\beta$-D-glucopyranosyl, $\mathbf{R}_{4}=$ $(1 \rightarrow 2)$ - $\alpha$-L-rhamnopyranosyl, $\mathrm{R}_{5}=\mathrm{OH}, \mathrm{R}_{6}=\mathrm{O}$

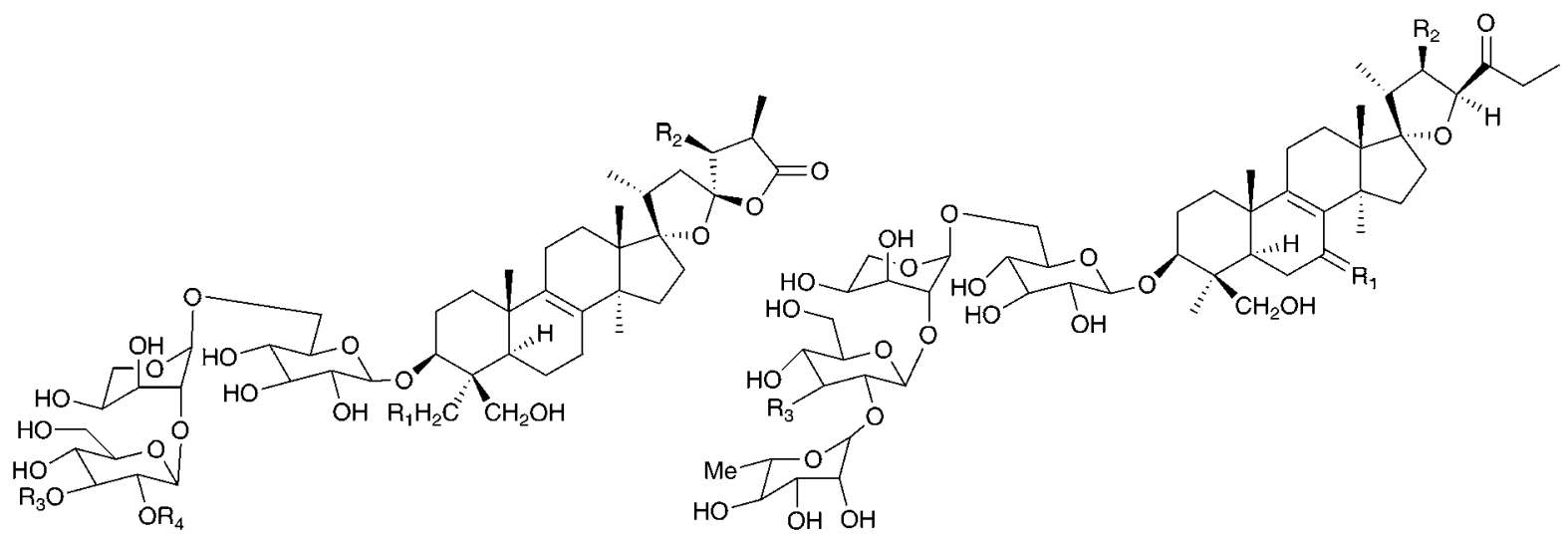

$236 \mathrm{R}_{1}=\mathrm{H}, \mathrm{R}_{2}=\mathrm{H}, \mathrm{R}_{3}=\alpha$-L-rhamnopyranosyl, $\mathrm{R}_{4}=\beta$-Dglucopyranosyl

$244 \mathrm{R}_{1}=\mathrm{H}, \mathrm{R}_{2}=\mathrm{OH}, \mathrm{R}_{3}=\beta$-D-glucopyranosyl- $(1 \rightarrow 3)-\beta-\mathrm{D}$ -

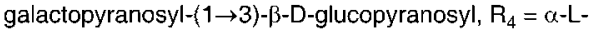
rhamnopyranosyl

$245 R_{1}=H, R_{2}=O H, R_{3}=-\alpha-D-x y l o p y r a n o s y l-\beta$-D-glucopyranosyl$(1 \rightarrow 3)$ - $\beta$-D-galactopyranosyl- $(1 \rightarrow 3)$ - $\beta$-D-glucopyranosyl, $R_{4}=\alpha$-Lrhamnopyranosyl

$246 R_{1}=O H_{1} R_{2}=H, R_{3}=\beta$-D-glucopyranosyl, $R_{4}=\alpha-L$ rhamnopyranosyl

$247 \mathrm{R}_{1}=\mathrm{H}, \mathrm{R}_{2}=\mathrm{OH}, \mathrm{R}_{3}=\mathrm{H}, \mathrm{R}_{4}=\alpha$-L-rhamnopyranosyl
$241 \mathrm{R}_{1}=\mathrm{O}, \mathrm{R}_{2}=\mathrm{OAc}, \mathrm{R}_{3}=\beta$-D-glucopyranosyl

$242 \mathrm{R}_{1}=2 \mathrm{H}, \mathrm{R}_{2}=\mathrm{H}, \mathrm{R}_{3}=\alpha$-D-xylopyranosyl $-\beta$-D -

glucopyranosyl- $(1 \rightarrow 3)-\beta-D$-galactopyranosyl- $(1 \rightarrow 3)-\beta-D$ glucopyranosyl,

$243 \mathrm{R}_{1}=2 \mathrm{H}, \mathrm{R}_{2}=\mathrm{H}, \mathrm{R}_{3}=\beta$-D-glucopyranosyl- $(1 \rightarrow 3)-\beta-$

D-galactopyranosyl-(1 $\rightarrow 3)$ - $\beta$-D-glucopyranosyl 
<smiles>[R]c1cc(/C=C/c2ccc(O)c(O)c2)cc(O)c1O</smiles><smiles>COc1cc([C@@]2(C)COc3cc(O)cc(O)c3C2=O)cc(O)c1O</smiles>

252<smiles>[R6]c1cc(C[C@@H]2COc3cc(OC)c(OC)c(O)c3C2=O)ccc1O</smiles>

$253 \mathrm{R}_{1}=\mathrm{Me}, \mathrm{R}_{2}=\mathrm{OH}$ $254 \mathrm{R}_{1}=\mathrm{H}, \mathrm{R}_{2}=\mathrm{OH}$<smiles>COc1c(O)cc2c(c1O)C(=O)/C(=C/c1ccc(O)c(O)c1)CO2</smiles>

255

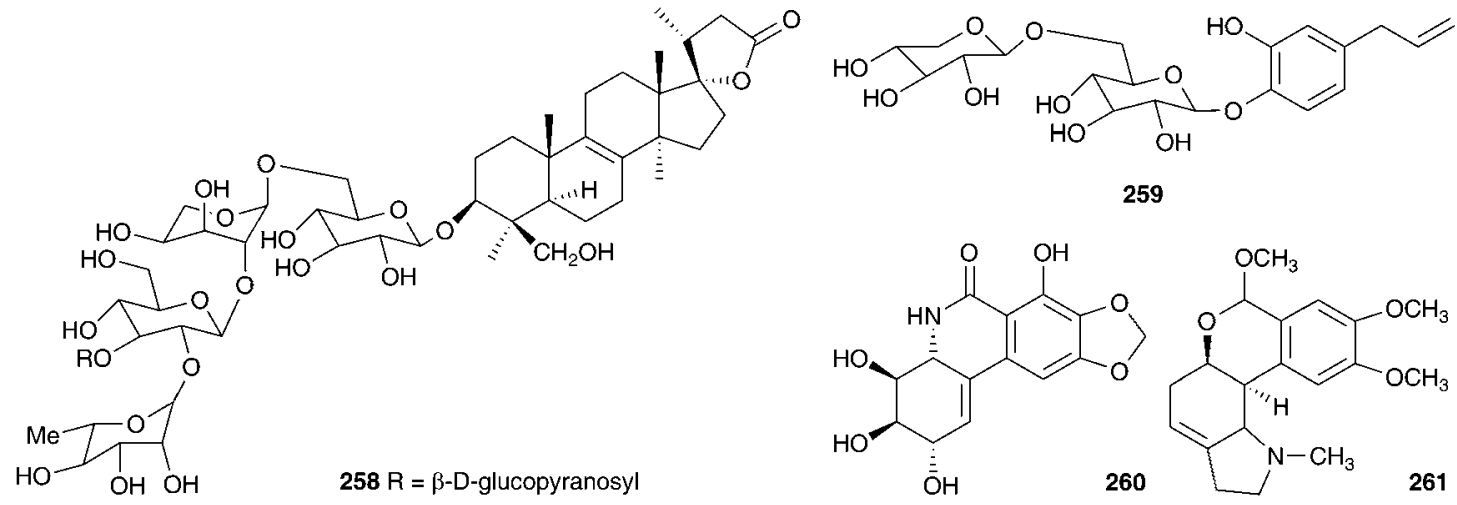

and identified five pyrrolidines (262-266), two pyrrolidine glycosides (267-268), six piperidines (269-274), one piperidine glycoside (275) and eight pyrrolizidines (276-283). ${ }^{127}$ These alkaloids were tested for their inhibitory activity against various glycosidases. Compound $\mathbf{2 6 2}$ was found to be a potent inhibitor of bacterial (Caldocellum sacchrolyticum) $\beta$-glucosidase and mammalian $\beta$-galactosidase $\left(\mathrm{IC}_{50}=3.2 \mu \mathrm{g} \mathrm{ml}^{-1}\right.$ and $4.4 \mu \mathrm{g} \mathrm{ml}{ }^{-1}$ respectively). The loss of the hydroxy group at C-6, to give compound 263, significantly lowered the activity. Moderate or no activity was found for all other compounds isolated. ${ }^{127}$

The bulbs of Oncostema peruviana (as Scilla peruviana) were found to contain rearranged lanosterol glycosides (scillasaponin B 284, peruvianoside A 285 , peruvianoside B 286, and compounds $187-188$ and $287-288)^{16,17,128,129}$ as well as a range of polyhydroxylated pyrrolidines (289-291) and pyrrolizidines $(292-295) .{ }^{130}$ Moderate inhibitory activity against cyclic AMP

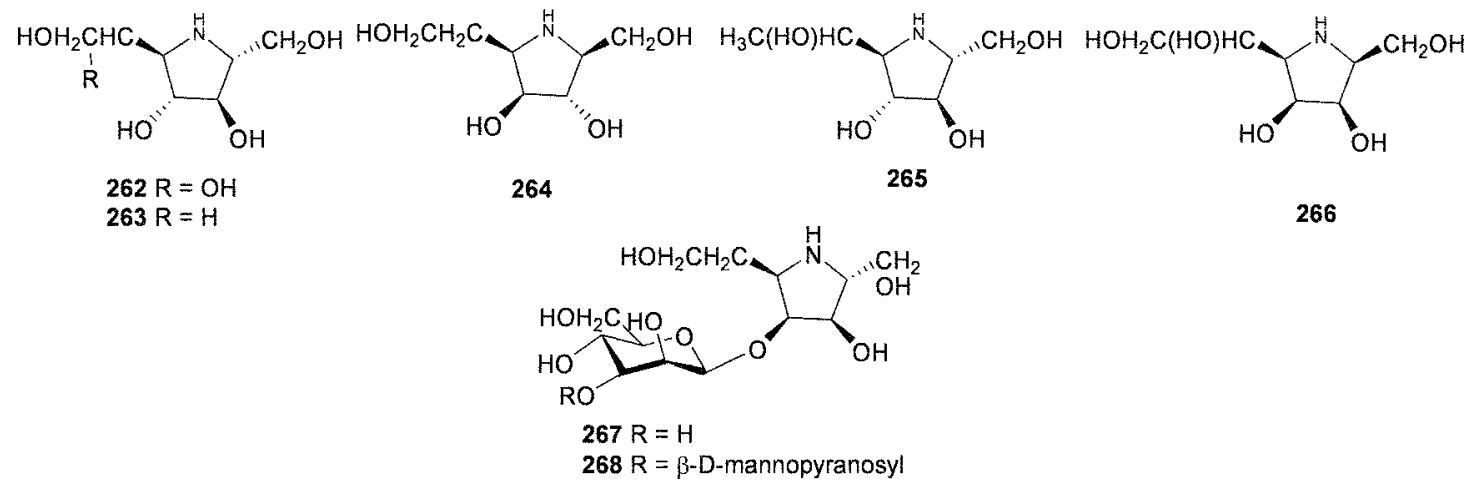




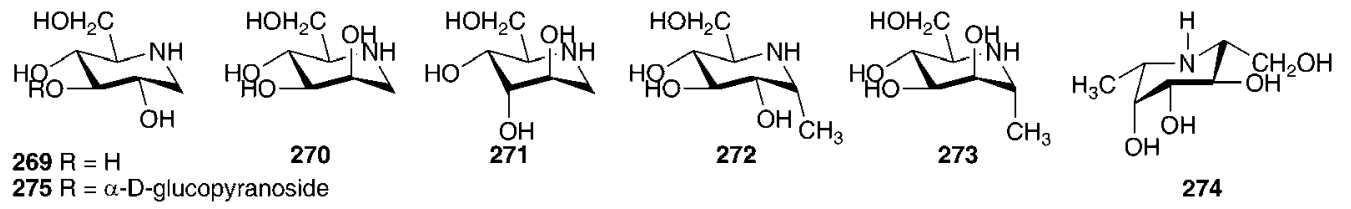<smiles>C[C@H]1[C@H]2CC[C@@H](C)N1[C@H](CO)[C@H](O)[C@@H]2O</smiles><smiles>C[C@@H]1CCC[C@H]2[C@H](O)C(O)[C@@H](CO)N21</smiles><smiles>C[C@@H]1CC[C@H]2[C@@H](O)[C@@H](O)[C@@H](CO)N21</smiles><smiles>C[C@@H]1C[C@H](O)[C@@H]2[C@@H](O)[C@H](O)[C@@H](CO)N12</smiles><smiles>C[C@@H]1C[C@@H](O)[C@H]2[C@H](O)[C@H](O)[C@H](CO)N21</smiles><smiles>C[C@@H]1C[C@H](O)[C@@H]2[C@@H](O)[C@@H](O)[C@H](CO)N12</smiles><smiles>C[C@@H]1CC(O)[C@H]2[C@@H](O)C(O)[C@@H](CO)N21</smiles>

phosphodiesterase was noted for peruvianoside A $285\left(\mathrm{IC}_{50}=\right.$ $\left.23.5 \times 10^{-5} \mathrm{M}\right)$ and scillasaponin B $286\left(\mathrm{IC}_{50}=14.0 \times 10^{-5}\right.$ $\mathrm{M}){ }^{16,128}$ while compound 187 , a 15 -deoxoeucosterol oligosaccharide, was found to be toxic to HeLa cells at a concentration of $5 \mu \mathrm{g} \mathrm{ml}{ }^{-1} \cdot{ }^{17}$ The pyrrolidine 291 was found to be a potent

inhibitor of bacterial $\beta$-glucosidase $\left(\mathrm{IC}_{50}=80 \mathrm{nM}\right)$, compounds 292 and 293 showed significant inhibition of yeast $\alpha$-glucosidase ( $\mathrm{IC}_{50}=6.6$ and $6.3 \mu \mathrm{M}$ respectively) with compound 293 also showing good inhibition of bacterial $\beta$-glucosidase $\left(\mathrm{IC}_{50}=\right.$ $5.1 \mu \mathrm{M}){ }^{130}$

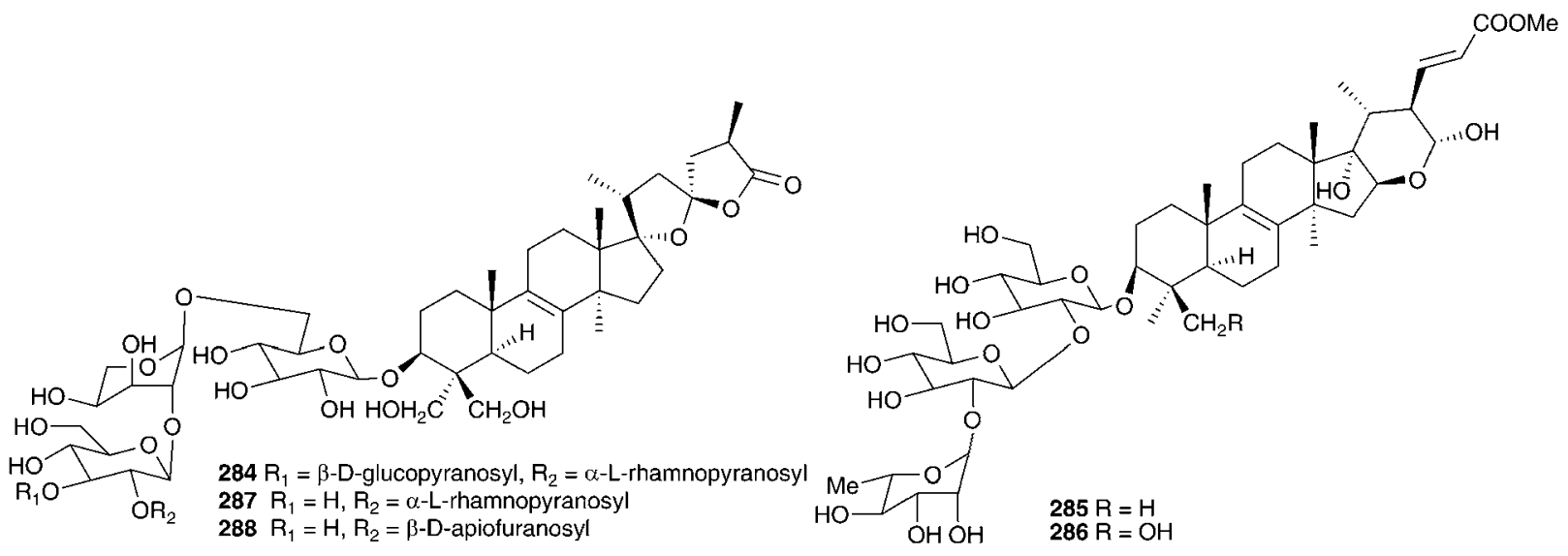<smiles>CC(O)C[C@@H]1NC(CO)[C@H](O)[C@H]1O</smiles>

289<smiles>CC(O)CC[C@@H]1C[C@@H](O)[C@@H]2[C@@H](O)[C@H](O)[C@@H](CO)N12</smiles>

292<smiles>CC(O)[C@@H](O)C1NC(CO)[C@H](O)[C@H]1O</smiles>

290<smiles>CC(O)CC[C@@H]1CC[C@H]2[C@@H](O)C(O)[C@H](CO)N12</smiles><smiles>OCC(O)CCCCC(O)CC(O)CCC[C@@H](O)[C@@H]1N[C@H](CO)[C@@H](O)[C@H]1O</smiles>

291 
Phytochemical work on the Hyacinthaceae has primarily focused on the bulbs. The exception to this has been the genus Hyacinthus, where most of the work has been done on the flowers. Hyacinthus orientalis is used as an ornamental plant and can have blue, pink, yellow or white flowers. The blue flowers of $H$. orientalis have been found to contain a range of acylated anthocyanins (296-302). ${ }^{131}$ The anthocyanin content was also studied in the blue flowers produced in vitro. The same anthocyanins were produced with some small changes in the percentage composition of the different compounds. ${ }^{132}$ The red flowers of $H$. orientalis likewise produced a range of acylated anthocyanins (303-316) and, as with the blue flowers, the red flowers produced in vitro produced the same anthocyanins with some differences in composition. ${ }^{133-135} \mathrm{~A}$ later investigation of the blue flowers of $H$. orientalis revealed a further seven anthocyanins (317-323) in addition to those isolated previously. ${ }^{\mathbf{1 3 6}}$ Differences in essential oil content between wild $H$. orientalis flowers and those generated in vitro have been studied. Four common components were found, 1-hepten-3-ol, benzyl alcohol, phenethyl alcohol and cinnamyl alcohol. The main components in the wild flowers were phenethyl alcohol (55\% at stage 3 and $48 \%$ at stage 4 ) and cinnamyl alcohol (23\% at stage 3 and $29 \%$ at stage 4 ) while the in vitro generated flowers produced $75 \%$ phenethyl alcohol as the major component. ${ }^{137}$ The bulbs of $H$. orientalis were found to be rich in polyhydroxy alkaloids. $\alpha$-Homonojirimycin 324 was the major component ${ }^{138}$ with the compounds 325-334 being found in smaller amounts. ${ }^{138,139}$ Compound 332 was found to be a good inhibitor of bacterial $\beta$-glucosidase $\left(\mathrm{IC}_{50}=3.8 \mu \mathrm{M}\right)$, mammalian $\beta$-galactosidases $\left(\mathrm{IC}_{50}=4.0 \mu \mathrm{M}\right.$ and $\left.4.4 \mu \mathrm{M}\right)$ and mammalian trehalases $(5.0 \mu \mathrm{M}$ and $2.0 \mu \mathrm{M}$ ), while compound 333 inhibited rice $\alpha$-glucosidase $\left(\mathrm{IC}_{50}=2.2 \mu \mathrm{M}\right)$ and rat intestinal maltase $\left(\mathrm{IC}_{50}=2.5 \mu \mathrm{M}\right)$ and compound 334 inhibited $\alpha$-L-fucosidase $\left(\mathrm{IC}_{50}=50 \mu \mathrm{M}\right){ }^{139}$

The methanol extract of the bulbs of Bellevalia paradoxa (Fisch. \& C.A.Mey.) Boiss. (as Muscari paradoxum (Fisch. et C.A. Mey.) K.Koch) yielded eight 27-norlanostane glycosides (335-342) $)^{55}$ and seven tetranorlanosterol glycosides $(\mathbf{2 5}, \mathbf{3 4 3 - 3 4 8 )}){ }^{54}$ All were tested

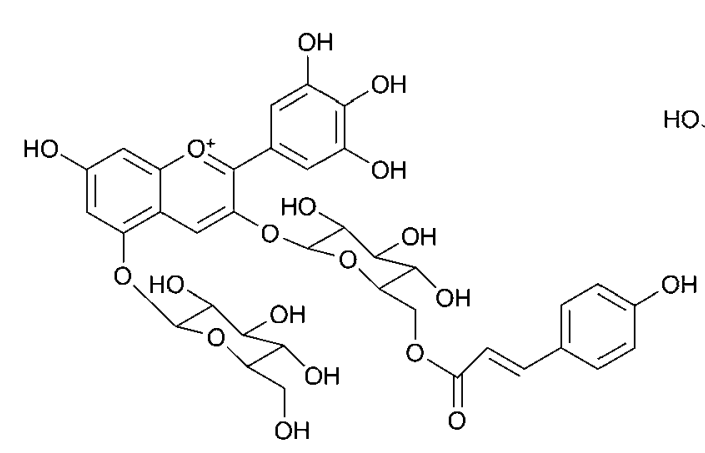

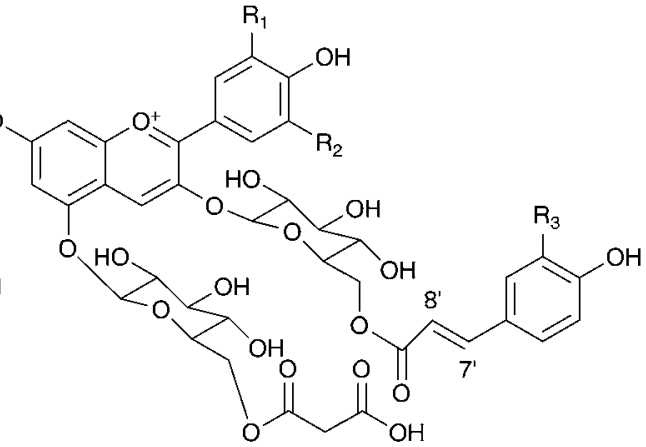

296

$297 \mathrm{R}_{1}=\mathrm{OH}, \mathrm{R}_{2}=\mathrm{OH}, \mathrm{R}_{3}=\mathrm{OH}, 7^{\prime} / 8$

trans

$298 \mathrm{R}_{1}=\mathrm{OH}, \mathrm{R}_{2}=\mathrm{OH}, \mathrm{R}_{3}=\mathrm{H}, 7^{\prime} / 8^{\prime} \mathrm{cis}$

$299 \mathrm{R}_{1}=\mathrm{OH}, \mathrm{R}_{2}=\mathrm{OH}, \mathrm{R}_{3}=\mathrm{H}, 7^{7} / 8^{\prime}$ trans

$300 R_{1}=O M e, R_{2}=O H, R_{3}=H, 7^{\prime} / 8^{\prime}$

trans

$301 \mathrm{R}_{1}=\mathrm{OH}, \mathrm{R}_{2}=\mathrm{H}, \mathrm{R}_{3}=\mathrm{H}, 7^{\prime} / 8^{\prime}$ trans

$302 \mathrm{R}_{1}=\mathrm{H}, \mathrm{R}_{2}=\mathrm{H}, \mathrm{R}_{3}=\mathrm{H}, 7^{\prime} / 8^{\prime}$ trans

$322 \mathrm{R}_{1}=\mathrm{H}, \mathrm{R}_{2}=\mathrm{OH}, \mathrm{R}_{3}=\mathrm{H}, 7^{\prime} / 8^{\prime}$ trans

$323 \mathrm{R}_{1}=\mathrm{OH}, \mathrm{R}_{2}=\mathrm{OMe}, \mathrm{R}_{3}=\mathrm{H}, 7^{\prime} / 8^{\prime}$

trans

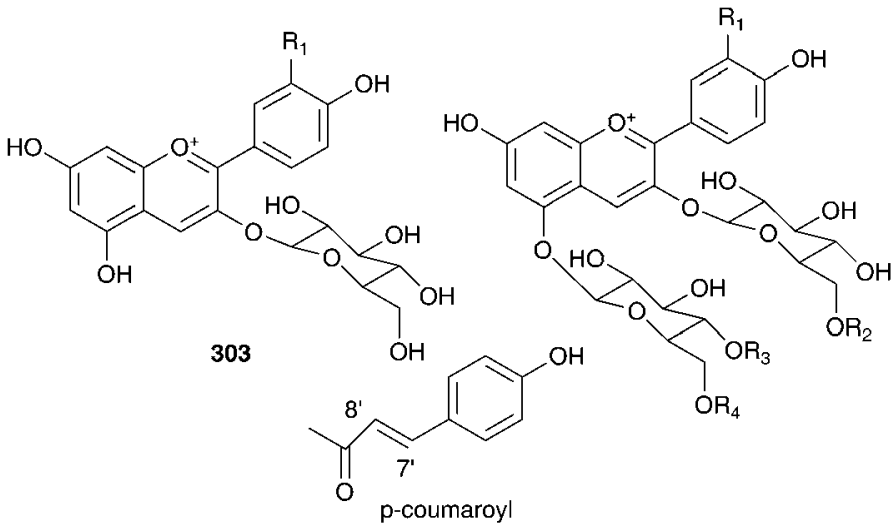

$304 \mathrm{R}_{1}=\mathrm{H}, \mathrm{R}_{2}=\mathrm{H}, \mathrm{R}_{3}=\mathrm{H}, \mathrm{R}_{4}=\mathrm{H}$

$305 \mathrm{R}_{1}=\mathrm{H}, \mathrm{R}_{2}=p$-coumaroyl, $\mathrm{R}_{3}=\mathrm{H}, \mathrm{R}_{4}=\mathrm{H}, 7^{\prime} / 8^{\prime} \mathrm{cis}$

$306 \mathrm{R}_{1}=\mathrm{H}, \mathrm{R}_{2}=p$-coumaroyl, $\mathrm{R}_{3}=\mathrm{H}^{\prime}, \mathrm{R}_{4}=\mathrm{H}, 7^{\prime} / 8^{\prime}$ trans

$307 \mathrm{R}_{1}=\mathrm{H}, \mathrm{R}_{2}=\mathrm{H}, \mathrm{R}_{3}=\mathrm{H}, \mathrm{R}_{4}=$ malonyl

$308 \mathrm{R}_{1}=\mathrm{H}, \mathrm{R}_{2}=p$-coumaroyl, $\mathrm{R}_{3}=\mathrm{H}, \mathrm{R}_{4}=$ malonyl, $7^{\prime} / 8^{\prime}$ cis

$309 \mathrm{R}_{1}=\mathrm{H}, \mathrm{R}_{2}=p$-coumaroyl, $\mathrm{R}_{3}=\mathrm{H}, \mathrm{R}_{4}=$ malonyl, $7^{\prime} / 8^{\prime}$ trans

$310 \mathrm{R}_{1}=\mathrm{H}, \mathrm{R}_{2}=p$-coumaroyl, $\mathrm{R}_{3}=$ malonyl, $\mathrm{R}_{4}=\mathrm{H}, 7^{\prime} / 8^{\prime}$ trans

$311 \mathrm{R}_{1}=\mathrm{OH}, \mathrm{R}_{2}=p$-coumaroyl, $\mathrm{R}_{3}=\mathrm{H}, \mathrm{R}_{4}=$ malonyl, $7^{\prime} / 8^{\prime}$ trans

$318 R_{1}=H, R_{2}=$ caffeoyl, $R_{3}=H, R_{4}=H$

319 $\mathrm{R}_{1}=\mathrm{H}, \mathrm{R}_{2}$ feruloyl, $\mathrm{R}_{3}=\mathrm{H}, \mathrm{R}_{4}=\mathrm{H}$

$320 R_{1}=H, R_{2}=$ feruloyl $R_{3}=H, R_{4}=$ malonyl

$321 R_{1}=H, R_{2}=$ caffeoyl, $R_{3}=H, R_{4}=$ malonyl

p-coumaroy 


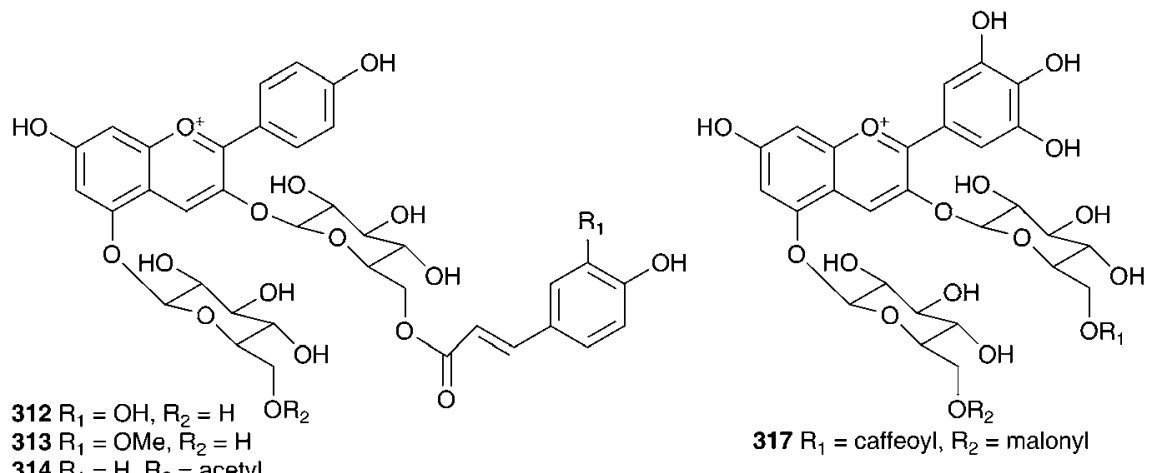<smiles>OC[C@H]1N[C@H](CO)[C@@H](O)C(O)[C@@H]1O</smiles>

324<smiles>OC[C@H]1NC[C@@H](O)[C@H](O)[C@@H]1O</smiles>

325

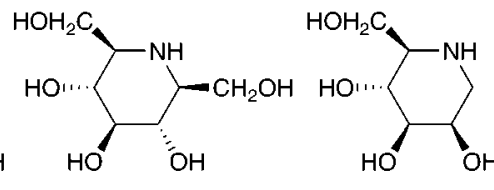

326

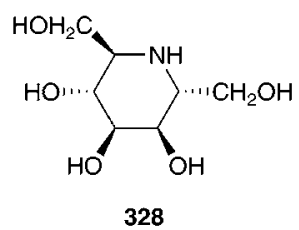<smiles>OC[C@H]1N[C@H](CO)[C@@H](O)[C@H](O)[C@H]1O</smiles>

329<smiles>[2H]OC[C@H]1N[C@H](CO)[C@@H](O)[C@@H](O)[C@@H]1O</smiles>

$330 \mathrm{R}=\beta$-D-glucopyranoside<smiles>OC[C@H]1N[C@H](CO)[C@@H](O)[C@@H]1O</smiles>

331<smiles>OC=C[C@H]1N[C@H](CO)[C@@H](O)[C@H]1O</smiles>

332<smiles>OCC[C@H]1N[C@H](CO)[C@@H](O)[C@H]1O</smiles>

for cytotoxicity against HSC-2 human oral squamous cell carcinoma. Compounds 25 and 343-344 showed no activity while compounds 345-348 gave $\mathrm{IC}_{50}$ values of $6.3-59 \mu \mathrm{g} \mathrm{ml}^{-1}$, with the standard etoposide giving an $\mathrm{IC}_{50}$ of $24 \mu \mathrm{g} \mathrm{ml}^{-1}$. Compounds 335, 336, 338, 340 and 341, all $23 S$ isomers, showed good activity relative to etoposide, but the corresponding $23 R$ isomers showed no activity up to a dose of $100 \mu \mathrm{g} \mathrm{ml}^{-1}$. The methanol extract of the bulbs of Bellevalia romana (L.) Sweet produced oligoglycosides of the eucosterol-type, four new compounds bellevaliosides A 349, B 350, C 351 and D 352 as well as compounds 86, 87 and 353, previously isolated from Muscari species. ${ }^{140}$ In addition to the spirocyclic nortriterpenoids, five homoisoflavanones (354-358) were isolated. ${ }^{141}$ The bulbs of Autonoe madeirensis (as Scilla maderensis Menezes), have produced a slightly unusual phytochemical profile. An investigation of the ethanol extract of the bulbs resulted in the isolation of a range of 2-hydroxy di- and tricarboxylic acids and esters, cis- and trans-hydroxycinnamate esters and a flavone diglucoside 359. ${ }^{142}$ A later study of the bulbs found $24 S$-ethyl-5 $\alpha$-cholesta-7,22E-dien-3-ol- $\beta$-galactopyranoside 360 to be present. ${ }^{143}$ Dias et al. isolated the pyrimidine derivative 2 -( $4^{\prime}$-aminobenzenamine)-pyrimidine and found it to be an $\alpha$-adrenoreceptor antagonist. ${ }^{\mathbf{1 4 4}}$

Work on the bulbs of Hyacinthoides hispanica (as Scilla campanulata) has focused on the isolation and structure determination of a mannose-specific lectin. Crystals have been grown and the structure determined by X-ray diffraction studies. ${ }^{\mathbf{1 4 5 - 1 4 9}}$ In addition to the mannose-binding lectin, a fetuin-binding lectin has been isolated and identified. ${ }^{150}$ Polyhydroxylated alkaloids have been isolated from the ethanol extract of the bulbs of $H$. hispanica (as Scilla campanulata) and tested for glycosidase inhibitory activity. Compounds 361-368 were identified with compound 364 showing good inhibition of Caldocellum saccharolyticum $\beta$-glucosidase $\left(\mathrm{IC}_{50}=3.8 \mu \mathrm{M}\right)$ and bovine liver $\beta$-galactosidase $\left(\mathrm{IC}_{50}=4.4 \mu \mathrm{M}\right)$. Compound 366 was more active than compound $\mathbf{3 6 4}$ against Caldocellum saccharolyticum $\beta$-glucosidase $\left(\mathrm{IC}_{50}=0.34 \mu \mathrm{M}\right)$, but less so of bovine liver $\beta$-galactosidase $\left(\mathrm{IC}_{50}=24 \mu \mathrm{M}\right){ }^{151}$

Hyacinthoides non-scripta (bluebells) has long been known to be toxic to livestock. Horses suffer from abdominal pain and dysentery while cattle suffer from lethargy and dullness after consuming the plants. The toxic principles are the polyhydroxy pyrrolidine and pyrrolizidine alkaloids, common to many Hyacinthoideae. ${ }^{151,152}$ Alkaloids 361-367, also found in Hyacinthoides hispanica (as Scilla campanulata), have been isolated from the leaves, stalks and immature fruits of the bluebells. ${ }^{151,152}$ A glucomannan has been isolated from the seeds of $H$. non-scripta. It is a linear polymer with D-glucopyranose and $\mathrm{D}^{-}$ mannopyranose residues occurring in the ratio of $1: 1.3 .^{153}$

Southern African genera that have received the attention of phytochemists are Drimiopsis, Resnova, Veltheimia, Merwilla, Lachenalia, Pseudoprospero, Schizocarphus and Spetaea. The range of compounds isolated is typical of the subfamily Hyacinthoideae, 


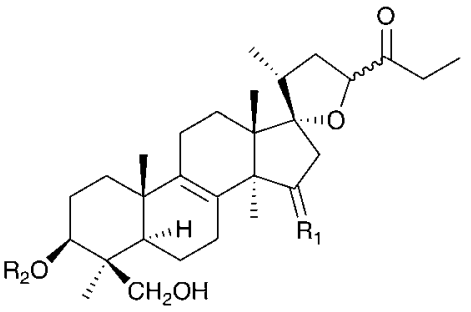

335 (23S) $\mathrm{R}_{1}=2 \mathrm{H}, \mathrm{R}_{2}=\alpha$-L-rhamnopyranosyl-(1 $\left.\rightarrow 2\right)-\beta$-D-glucopyranosyl-( $\left.1 \rightarrow 2\right)-\beta-\mathrm{L}-$ arabinopyranosyl- $(1 \rightarrow 6)-\beta$-D-glucopyranoside

$336(23 S) R_{1}=O, R_{2}=\alpha$-L-rhamnopyranosyl- $(1 \rightarrow 2)-\beta$-D-glucopyranosyl- $(1 \rightarrow 2)-\beta$-Larabinopyranosyl- $(1 \rightarrow 6)$ - $\beta$-D-glucopyranoside $337(23 R) R_{1}=O, R_{2}=\alpha$-L-rhamnopyranosyl-( $\left.1 \rightarrow 2\right)-\beta$-D-glucopyranosyl- $(1 \rightarrow 2)-\beta$-Larabinopyranosyl- $(1 \rightarrow 6)-\beta$-D-glucopyranoside

338 (23S) $R_{1}=O, R_{2}=\beta$-apiofuranosyl- $(1 \rightarrow 2)$ - $\beta$-D-glucopyranosyl-( $\left.1 \rightarrow 2\right)-\beta$-Larabinopyranosyl- $(1 \rightarrow 6)$ - $\beta$-D-glucopyranoside

$339(23 R) R_{1}=O, R_{2}=\beta$-apiofuranosyl-(1 $\left.\rightarrow 2\right)$ - $\beta$-D-glucopyranosyl- $(1 \rightarrow 2)-\beta$ - Larabinopyranosyl- $(1 \rightarrow 6)-\beta$-D-glucopyranoside

340 (23S) $R_{1}=2 H, R_{2}=[\alpha-L-$ rhamnopyranosyl- $(1 \rightarrow 2)]-[-\alpha-D$-xylopyranosyl- $(1 \rightarrow 2)-\beta-$

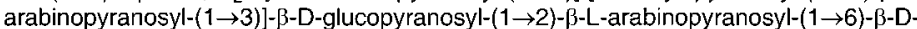
glucopyranoside

$341(23 S) R_{1}=O, R_{2}=[\alpha-L-r h a m n o p y r a n o s y l-(1 \rightarrow 2)]-[-\alpha-D-x y l o p y r a n o s y l-(1 \rightarrow 2)-\beta-$ arabinopyranosyl-( $(1 \rightarrow 3)]-\beta$-D-glucopyranosyl-( $(1 \rightarrow 2)-\beta$-L-arabinopyranosyl-( $(1 \rightarrow 6)-\beta-D$ glucopyranoside

$342(23 R) \mathrm{R}_{1}=\mathrm{O}, \mathrm{R}_{2}=[\alpha$-L-rhamnopyranosyl- $(1 \rightarrow 2)]-[-\alpha-\mathrm{D}$-xylopyranosyl $-(1 \rightarrow 2)-\beta$ arabinopyranosyl- $(1 \rightarrow 3)$ - $\beta$-D-glucopyranosyl-( $(1 \rightarrow 2)-\beta$-L-arabinopyranosyl-( $(1 \rightarrow 6)-\beta$-D glucopyranoside

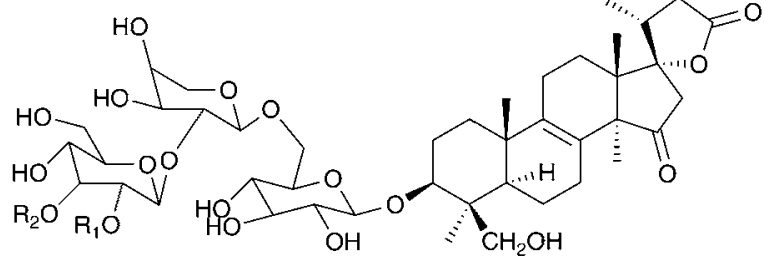

$343 \mathrm{R}_{1}=\alpha$-L-rhamnopyranosyl, $\mathrm{R}_{2}=\beta$-L-arabinpyranosyl $344 R_{1}=\alpha$-L-rhamnopyranosyl, $R_{2}=\alpha$-L-arabinofuranyl$(1 \rightarrow 2)-\beta$-L-arabinopyranosyl

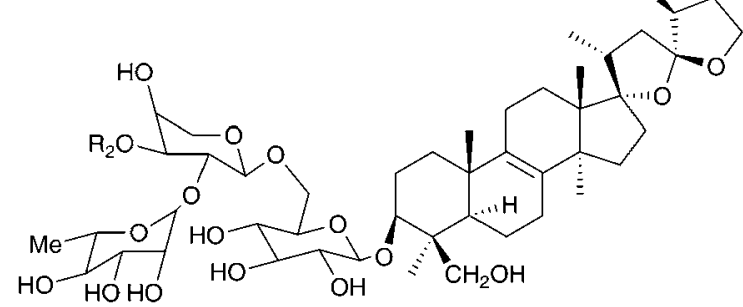

$345 \mathrm{R}_{1}=\mathrm{H}, \mathrm{R}_{2}=\beta$-L-arabinopyranosyl

$346 R_{1}=H, R_{2}=\alpha$-L-arabinofuranyl- $(1 \rightarrow 2)-\beta$-L-arabinopyranosyl $347 \mathrm{R}_{1}=\mathrm{OH}, \mathrm{R}_{2}=\alpha$-L-arabinofuranyl- $(1 \rightarrow 2)-\beta$-L-arabinopyranosyl $348 R_{1}=H, R_{2}=H$

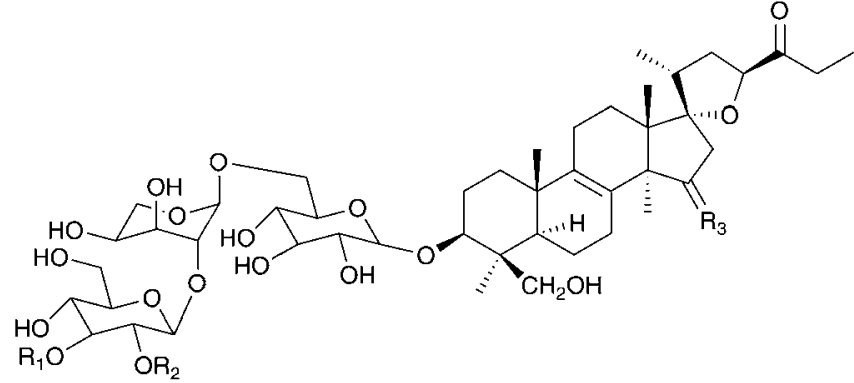

$349 R_{1}=\alpha$-L-rhamnosyl, $R_{2}=D$-apiofuranosyl- $(1 \rightarrow 2)$-D-xylopyranosyl, $\mathbf{R}_{3}=0$ $350 R_{1}=\alpha$-L-rhamnosyl, $R_{2}=D$-xylopyranosyl, $R_{3}=0$

$351 R_{1}=D$-apiofuranosyl,$R_{2}=D$-apiofuranosyl- $(1 \rightarrow 2)$-D-xylopyranosyl, $R_{3}=0$ $352 \mathrm{R}_{1}=\alpha$-L-rhamnosyl, $\mathrm{R}_{2}=\mathrm{D}$-apiofuranosyl- $(1 \rightarrow 2)$-D-xylopyranosyl, $\mathbf{R}_{3}=\mathrm{OH}$

$353 \mathrm{R}_{1}=\alpha$-L-rhamnosyl, $\mathrm{R}_{2}=\mathrm{D}$-apiofuranosyl- $(1 \rightarrow 2)$-L-arabinopyranosyl, $\mathrm{R}_{3}=\mathrm{O}$<smiles>COc1cc(O)c2c(c1O)OC/C(=C\c1ccc(O)c(O)c1)C2=O</smiles><smiles>O=c1cc(-c2ccc(O)cc2)oc2cc(O)cc(O)c12</smiles><smiles>[R6]c1cc(C[C@H]2COc3c([R])c([R])c([2H])c(O)c3C2=O)ccc1O</smiles>

$354 \mathrm{R}_{1}=\mathrm{OMe}, \mathrm{R}_{2}=\mathrm{OMe}, \mathrm{R}_{3}=\mathrm{OH}, \mathrm{R}_{4}=\mathrm{OH}$

$356 \mathrm{R}_{1}=\mathrm{H}, \mathrm{R}_{2}=\mathrm{H}, \mathrm{R}_{3}=\mathrm{H}, \mathrm{R}_{4}=\mathrm{OH}$

$357 \mathrm{R}_{1}=\mathrm{OH}, \mathrm{R}_{2}=\mathrm{OMe}, \mathrm{R}_{3}=\mathrm{H}, \mathrm{R}_{4}=\mathrm{H}$

$358 \mathrm{R}_{1}=\mathrm{OH}, \mathrm{R}_{2}=\mathrm{OMe}, \mathrm{R}_{3}=\mathrm{OMe}, \mathrm{R}_{4}=\mathrm{H}$

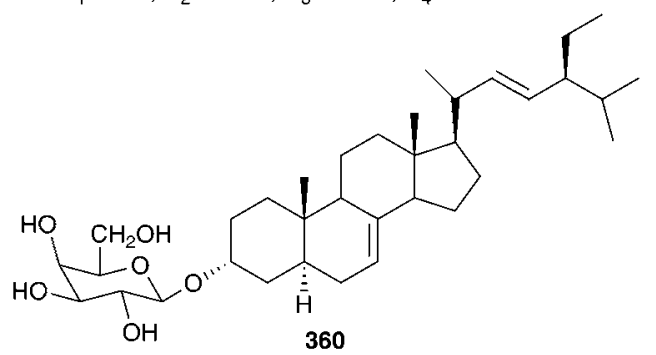

$359 \mathrm{R}=\beta$-D-glucopyranosyl-(1 $\rightarrow 2)-\beta-D$-glucopyranoside<smiles>O=CC1NC(O)C2CC1O2</smiles>

361<smiles>OC[C@@H]1CC[C@H]2[C@@H](O)[C@H](O)[C@H](CO)N12</smiles><smiles>O=CC1NC(O)C2COCC1C2O</smiles>

362<smiles>OC[C@@H]1C[C@H](O)[C@H](O)C1</smiles>

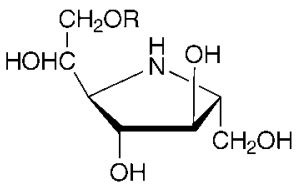

$364 \mathrm{R}=\mathrm{H}$

$365 \mathrm{R}=$ apiopyranoside

$366 \mathrm{R}=\beta$-D-xylopyranoside 
including homoisoflavanones, spirocyclic nortriterpenoids and xanthones, as well as some more unusual alkaloids. Three species of Drimiopsis have been studied, Drimiopsis maculata Lindl. \& Paxton, Drimiopsis burkei and Drimiopsis barteri Baker. Drimiopsis maculata is a southern African species used by traditional healers for treating a variety of complaints, including stomach complaints in children and the relief of constipation. It has not been found to be toxic to livestock. ${ }^{25}$ The bulbs of this plant have yielded scillascillin-type homoisoflavanones (compound 106, previously isolated from Muscari botryoides and compound 182, previously isolated from $M$. botryoides and $M$. armeniacum), ${ }^{154}$ xanthones (drimiopsins A-E, 163, 369, 138 and 370-372), ${ }^{25}$ three homoisoflavanones $(\mathbf{3 0}, \mathbf{5 9}, \mathbf{3 7 3})$ and a norlignan $374 .{ }^{69}$ Drimiopsis burkei is widespread throughout Botswana and Zimbabwe, occurring southward towards the Eastern Cape Province of South Africa. ${ }^{69}$ In Botswana it is known as thejane and is used to treat stomach complaints. ${ }^{155}$ A sample of this plant collected in KwaZulu-Natal, South Africa was found to contain the norlignan hinokiresinol 155 and a homoisoflavanone $375,{ }^{69}$ while a sample collected in Mochudi, Botswana was found to contain the scillascillin-type homoisoflavanones (248 and 376), xanthones $(\mathbf{1 3 7}, \mathbf{1 3 8}, \mathbf{3 6 9}$, 377-378), the norlignan hinokiresinol 155 and the homoisoflavanones (E- eucomin 6, 104, 128 and 379-382). ${ }^{155}$ Drimiopsis barteri is the only genus member to occur in Cameroon, where it is used to treat fever. ${ }^{156}$ The bulbs have been found to contain the unusual isoquinoline alkaloids ( $\mathbf{3 8 3}$ and $\mathbf{3 8 4}$ ) as well as the more expected scillascillin-type homoisoflavanones $(\mathbf{1 6 1}, \mathbf{3 7 6}$, 385-387), 3-benzyl-4-chromanones (61, 214 and 388) and Z-eucomin 6. While the configuration at $\mathrm{C}-3$ was not specified, the data compared favourably to known compounds of this type and would appear to be $R \cdot{ }^{155,156}$ The homoisoflavanones $144,373,375,387$ and 389-391, were tested against the Gram-positive, methicillin-resistant Staphylococcus aureus. Compound 391 was found to have significant inhibitory activity with an MIC value of $0.47 \mathrm{mM}$. Compounds 389 and 375 showed some activity, but the quantities available were insufficient for conclusive testing. ${ }^{41}$ The homoisoflavanone 389, showed significant vasodilating effects when tested on rat aortic rings (inhibition of the contraction elicited in aorta rings by high $\mathrm{K}^{+}$gave $\mathrm{pIC}_{50}$ of $5.31 \mathrm{M}$ ). This result would serve to validate the use of these bulbs for the treatment of conditions involving vasoconstriction. ${ }^{157}$ Resnova humifusa (Baker) U.Müll.Doblies \& D.Müll.-Doblies, a South African species, earlier placed in Drimiopsis by Jessop ${ }^{40}$ was found to contain nine homoisoflavanones $(\mathbf{7}, \mathbf{1 0}, \mathbf{3 0}, \mathbf{5 6}-\mathbf{6 0}, \mathbf{3 9 2})$. The same study reported seven<smiles>[R6]c1c([125I])c(O)c2c(=O)c3c(C)cc(Br)c([R6])c3oc2c1[2H]</smiles>

$369 \mathrm{R}_{1}=\mathrm{OH}, \mathrm{R}_{2}=\mathrm{H}, \mathrm{R}_{3}=\mathrm{OMe}, \mathrm{R}_{4}=\mathrm{OMe}, \mathrm{R}_{5}=\mathrm{OMe}$ $370 \mathrm{R}_{1}=\mathrm{OH}, \mathrm{R}_{2}=\mathrm{OMe}, \mathrm{R}_{3}=\mathrm{OMe}, \mathrm{R}_{4}=\mathrm{OH}, \mathrm{R}_{5}=\mathrm{H}$ $371 \mathrm{R}_{1}=\mathrm{OH}, \mathrm{R}_{2}=\mathrm{H}, \mathrm{R}_{3}=\mathrm{OMe}, \mathrm{R}_{4}=\mathrm{OH}, \mathrm{R}_{5}=\mathrm{H}$ $372 \mathrm{R}_{1} \mathrm{OMe}, \mathrm{R}_{2}=\mathrm{H}, \mathrm{R}_{3}=\mathrm{H}, \mathrm{R}_{4}=\mathrm{OH}, \mathrm{R}_{5}=\mathrm{OMe}$ $377 \mathrm{R}_{1}=\mathrm{OH}, \mathrm{R}_{2}=\mathrm{H}, \mathrm{R}_{3}=\mathrm{H}, \mathrm{R}_{4}=\mathrm{OMe}, \mathrm{R}_{5}=\mathrm{OMe}$ $378 \mathrm{R}_{1}=\mathrm{OMe}, \mathrm{R}_{2}=\mathrm{H}, \mathrm{R}_{3}=\mathrm{OH}, \mathrm{R}_{4}=\mathrm{OMe}, \mathrm{R}_{5}=\mathrm{OMe}$<smiles>[R6]c1cc([C@]2(C)COc3cc(Br)c([R2])c(O)c3C2=O)cc([R5])c1[2H]</smiles>

$376 \mathrm{R}_{1}=\mathrm{OH}, \mathrm{R}_{2}=\mathrm{H}, \mathrm{R}_{3}=\mathrm{OMe}, \mathrm{R}_{4}=\mathrm{OMe}, \mathrm{R}_{5}=\mathrm{OMe}$ $385 \mathrm{R}_{1}=\mathrm{OMe}, \mathrm{R}_{2}=\mathrm{H}, \mathrm{R}_{3}=\mathrm{OMe}, \mathrm{R}_{4}=\mathrm{OMe}, \mathrm{R}_{5}=\mathrm{OMe}$ $386 \mathrm{R}_{1}=\mathrm{OMe}, \mathrm{R}_{2}=\mathrm{H}, \mathrm{R}_{3}=\mathrm{OMe}, \mathrm{R}_{4}=\mathrm{OH}, \mathrm{R}_{5}=\mathrm{OH}$ $387 \mathrm{R}_{1}=\mathrm{OMe}, \mathrm{R}_{2}=\mathrm{H}, \mathrm{R}_{3}=\mathrm{OH}, \mathrm{R}_{4}=\mathrm{OMe}, \mathrm{R}_{5}=\mathrm{H}$<smiles></smiles><smiles>[R6]c1ccc(C[C@H]2COc3c([R9])c([R3])c([R3])c([R6])c3C2=O)cc1[R6]</smiles>

$373 \mathrm{R}_{1}=\mathrm{H}, \mathrm{R}_{2}=\mathrm{OMe}, \mathrm{R}_{3}=\mathrm{OH}, \mathrm{R}_{4}=\mathrm{OH}, \mathrm{R}_{5}=\mathrm{H}, \mathrm{R}_{6}=\mathrm{OH}$ $375 \mathrm{R}_{1}=\mathrm{H}, \mathrm{R}_{2}=\mathrm{OMe}, \mathrm{R}_{3}=\mathrm{H}, \mathrm{R}_{4}=\mathrm{OMe}, \mathrm{R}_{5}=\mathrm{H}, \mathrm{R}_{6}=\mathrm{OH}$ $379 \mathrm{R}_{1}=\mathrm{H}, \mathrm{R}_{2}=\mathrm{OH}, \mathrm{R}_{3}=\mathrm{OMe}, \mathrm{R}_{4}=\mathrm{OMe}, \mathrm{R}_{5}=\mathrm{H}, \mathrm{R}_{6}=\mathrm{OH}$ $380 R_{1}=H, R_{2}=O M e, R_{3}=O M e R_{4}=O H, R_{5}=H, R_{6}=O H$ $381 \mathrm{R}_{1}=\mathrm{H}, \mathrm{R}_{2}=\mathrm{OMe}, \mathrm{R}_{3}=\mathrm{OMe} \mathrm{R}=\mathrm{OMe}, \mathrm{R}_{5}=\mathrm{H}, \mathrm{R}_{6}=\mathrm{OH}$ $388 \mathrm{R}_{1}=\mathrm{H}, \mathrm{R}_{2}=\mathrm{OH}, \mathrm{R}_{3}=\mathrm{OH}, \mathrm{R}_{4}=\mathrm{OH}, \mathrm{R}_{5}=\mathrm{H}, \mathrm{R}_{6}=\mathrm{OH}$ $389 \mathrm{R}_{1}=\mathrm{H}, \mathrm{R}_{2}=\mathrm{OH}, \mathrm{R}_{3}=\mathrm{HR}_{4}=\mathrm{OH}, \mathrm{R}_{5}=\mathrm{H}, \mathrm{R}_{6}=\mathrm{OH}$ $390 \mathrm{R}_{1}=\mathrm{H}, \mathrm{R}_{2}=\mathrm{OH}, \mathrm{R}_{3}=\mathrm{HR} \mathrm{R}_{4}=\mathrm{OH}, \mathrm{R}_{5}=\mathrm{OMe}, \mathrm{R}_{6}=\mathrm{OH}$ $391 \mathrm{R}_{1}=\mathrm{OMe}, \mathrm{R}_{2}=\mathrm{OMe}, \mathrm{R}_{3}=\mathrm{HR}_{4}=\mathrm{OH}, \mathrm{R}_{5}=\mathrm{H}, \mathrm{R}_{6}=\mathrm{OH}$ $392 \mathrm{R}_{1}=\mathrm{H}, \mathrm{R}_{2}=\mathrm{OH}, \mathrm{R}_{3}=\mathrm{HR}_{4}=\mathrm{OH}, \mathrm{R}_{5}=\mathrm{OH}, \mathrm{R}_{6}=\mathrm{OMe}$ $394 R_{1}=O H, R_{2}=O M e, R_{3}=O M e, R_{4}=O H, R_{5}=H, R_{6}=$ $\mathrm{OH}$<smiles>COc1ccc(/C=C2\COc3c(O)c(OC)cc(O)c3C2=O)cc1</smiles><smiles>[R5]c1c([B])c(OC)cc2c1-c1ncc3c(OC)c(OC)c(OC)cc3c1CO2</smiles>

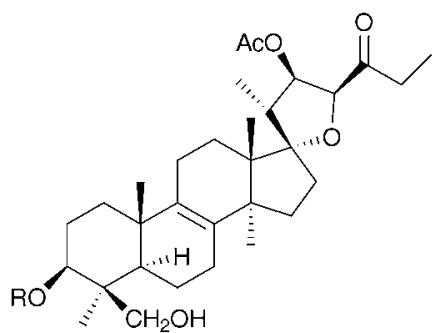<smiles>C[C@@H]1CCC[C@@H]2[C@@H](O)[C@H]([18OH])[C@@H](CO)N12</smiles>

$395 \mathrm{R}=\beta$-D-glucopyranosyl- $(1 \rightarrow 6)-\mathrm{O}-\alpha-\mathrm{L}-$ arabinopyranosyl- $(1 \rightarrow 2)-O-(3-O-\beta-D-$ glucopyranosyl-( $(\rightarrow 3))-\beta$-D-glucopyranosyl$(1 \rightarrow 2)$-O- $\beta$-D-apio-D-furanoside 
to be common with those found in the South African species Eucomis montana $(7, \mathbf{1 0}, 30,56,58,59,60)$, which in addition contained compound $\mathbf{8 .}{ }^{40}$ A later study on the methanol extract of the bulbs of this plant resulted in the isolation of four homoisoflavanones $(\mathbf{5 0}, \mathbf{5 8}, \mathbf{5 9}, \mathbf{6 1})$, a chalcone 132 and a tetrahydropyran derivative $393 .{ }^{42}$

Veltheimia bracteata Harv. ex Baker is indigenous to South Africa. The petroleum ether and diethyl ether extracts of bulbs (as Veltheimia viridifolia) grown from seeds in Berlin have yielded two homoisoflavanones (394 and muscomin, 97) ${ }^{\mathbf{1 5 8}}$ as well as a spirocyclic nortriterpenoid 133 and its pentaglycoside 395 from the petrol and chloroform extracts respectively. ${ }^{159}$ The homoisoflavanone 394, was found to exhibit good inhibitory activity against phosphodiesterase (PDE). ${ }^{158}$ Compound 394 was found to inhibit the two PDE-isoenzymes by $70 \%$ and $75 \%$ at a concentration of $100 \mu \mathrm{mol} \mathrm{l}^{-1}{ }^{\mathbf{1 5 8}}$ Veltheimia capensis (L.) DC., native to the Western Cape, South Africa, has been found to contain an indolizidine alkaloid, steviamine 396. This alkaloid is also present in Stevia rebaudiana Bertoni (Asteraceae), but such alkaloids have not yet been isolated from any other Hyacinthaceae taxa. ${ }^{160}$

Merwilla plumbea (Lindl.) Speta is widely used by southern African traditional healers. The Zulu use it as a purgative and to facilitate full term labour. The Sotho eat the cooked bulbs as an aperient, use bulb decoctions in enemas to treat internal tumours and for the treatment of lung disease in cattle. Powdered bulbs are rubbed on sprains and fractures by the Southern Sotho, while the Tswana believe that bulbs rubbed on the body will make them resistant to witchcraft. The Swati use a lotion prepared from the bulbs to treat veldsores and boils. ${ }^{161,162}$ Concern for the sustainability of Merwilla plumbea has led Ncube et al. to include the bulbs of this plant in a study to compare the antibacterial, anticandidal and cyclooxygenase inhibitory activity of the leaves and the, more commonly harvested, bulbs of some popular medicinal plants, harvested during different seasons in the year. Antimicrobial activities between the leaves and bulbs of Merwilla plumbea were found to be comparable over all four seasons and as such they concluded that the leaves could be used in many cases as a substitute for the bulbs. Likewise both the leaves and bulbs produced good cyclooxygenase inhibitory activity throughout the year. ${ }^{\mathbf{1 6 3 , 1 6 4}} \mathrm{A}$ further study found that in vitro propagation of these plants could, under the right conditions, result in an increase in the flavonoid and gallotannin levels found in the shoots, which would allow for the successful mass propagation of these plants containing elevated levels of the potentially medicinally active components. ${ }^{110,161}$ A phytochemical investigation of the bulbs (as Scilla natalensis Planch.) found two homoisoflavanones 62 and 72, seven known eucosterol-type spirocyclic nortriterpenoids and the new spirocyclic nortriterpenoids 397, 398 and 399. ${ }^{161}$ An extract of the lectin-like proteins from the bulbs of M. plumbea (as Merwilla natalensis Planch.) have been found to exhibit moderate inhibitory activity (47\%) against cyclooxygenase (COX-1). ${ }^{31}$ In a separate study, the homoisoflavanones 62 and $\mathbf{4 0 0}$ have been isolated from M. plumbea (as Scilla natalensis Planch.). ${ }^{\mathbf{1 6 2}}$ In addition M. plumbea (as S. natalensis) has been shown to have good in vitro activity against the parasite Schistosoma haematobium $\left(\mathrm{LC}=0.4 \mathrm{mg} \mathrm{ml}^{-1}\right){ }^{66}$ Three homoisoflavanones $(7,62,401)$ have been isolated from Merwilla dracomontana (Hilliard \& B.L. Burtt) Speta (as Scilla dracomontana Hillard and Burtt). ${ }^{162}$ A southern African member of the genus Merwilla, under its basionym Scilla krausii Baker, was found to contain the homoisoflavanone, $\mathbf{8 0 .}{ }^{162}$

Lachenalia is the largest endemic genus of the Hyacinthaceae in southern Africa. Surprisingly, very little phytochemical work has been done on the genus. ${ }^{165}$ A study of the leaves of Lachenalia unifolia Jacq. has yielded flavone sulphates (luteolin- $3^{\prime}$-sulphate and $-7,3^{\prime}$-disulphate, tricetin- $3^{\prime}$-sulphate and $-7,3^{\prime}$ disulphate, diosmetin- $3^{\prime}$-sulphate and -7,3'-disulphate) ${ }^{\mathbf{1 6 6}}$ while the bulbs of L. rubida Jacq., collected from the Western Cape, South Africa, were found to contain the homoisoflavanones 402 and $403 .{ }^{165}$ The bulbs of Pseudoprospero firmifolium (Baker) Speta have been found to contain five 3-hydroxy-3-benzyl-4-chromanone type

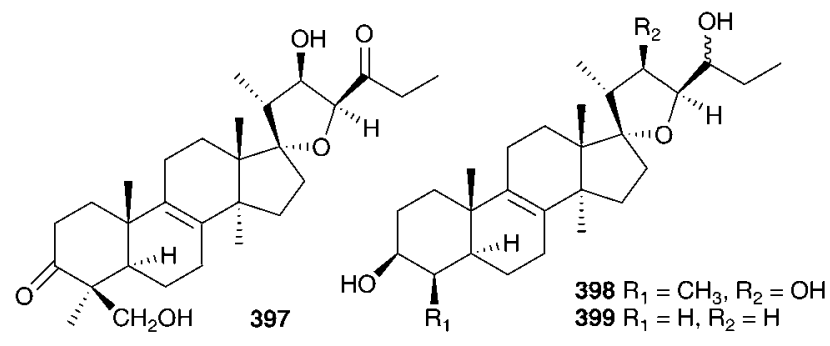

$398 \mathrm{R}_{1}=\mathrm{CH}_{3}, \mathrm{R}_{2}=\mathrm{OH}$
$399 \mathrm{R}_{1}=\mathrm{H}, \mathrm{R}_{2}=\mathrm{H}$<smiles>[R6]c1ccc(C[C@H]2COc3c([R7])c([R6])c([2H])c([R6])c3C2=O)cc1[R6]</smiles>

$400 \mathrm{R}_{1}=\mathrm{H}, \mathrm{R}_{2}=\mathrm{OH}, \mathrm{R}_{3}=\mathrm{OMe}, \mathrm{R}_{4}=\mathrm{OH}, \mathrm{R}_{5}=\mathrm{OH}, \mathrm{R}_{6}=\mathrm{OMe}$ $401 R_{1}=H, R_{2}=O H, R_{3}=O M e, R_{4}=O H, R_{5}=H, R_{6}=O M e$ $403 \mathrm{R}_{1}=\mathrm{H}, \mathrm{R}_{2}=\mathrm{OMe}, \mathrm{R}_{3}=\mathrm{H}, \mathrm{R}_{4}=\mathrm{OH}, \mathrm{R}_{5}=\mathrm{H}, \mathrm{R}_{6}=\mathrm{OH}$ $409 R_{1}=H, R_{2}=O M e, R_{3}=H, R_{4}=O H, R_{5}=H, R_{6}=O M e$ $410 R_{1}=H, R_{2}=O M e, R_{3}=H, R_{4}=O M e, R_{5}=O H, R_{6}=O M e$ $411 R_{1}=H, R_{2}=O M e, R_{3}=H, R_{4}=O M e, R_{5}=H, R_{6}=O H$ $412 \mathrm{R}_{1}=\mathrm{H}, \mathrm{R}_{2}=\mathrm{OMe}, \mathrm{R}_{3}=\mathrm{H}, \mathrm{R}_{4}=\mathrm{OH}, \mathrm{R}_{5}=\mathrm{H}, \mathrm{R}_{6}=\mathrm{OMe}$ $417 \mathrm{R}_{1}=\mathrm{H}, \mathrm{R}_{2}=\mathrm{OMe}, \mathrm{R}_{3}=\mathrm{H}, \mathrm{R}_{4}=\mathrm{OMe}, \mathrm{R}_{5}=\mathrm{H}, \mathrm{R}_{6}=\mathrm{OMe}$ $418 R_{1}=H, R_{2}=O M e, R_{3}=H, R_{4}=O H, R_{5}=O M e, R_{6}=O H$ $419 \mathrm{R}_{1}=\mathrm{H}, \mathrm{R}_{2}=\mathrm{OH}, \mathrm{R}_{3}=\mathrm{H}, \mathrm{R}_{4}=\mathrm{OH}, \mathrm{R}_{5}=\mathrm{OH}, \mathrm{R}_{6}=\mathrm{OMe}$

$420 R_{1}=H, R_{2}=O M e, R_{3}=O M e, R_{4}=O H, R_{5}=O M e, R_{6}=O H$

$421 R_{1}=H, R_{2}=O H, R_{3}=O M e, R_{4}=O H, R_{5}=H, R_{6}=O H$

$422 \mathrm{R}_{1}=\mathrm{H}, \mathrm{R}_{2}=\mathrm{OH}, \mathrm{R}_{3}=\mathrm{H}, \mathrm{R}_{4}=\mathrm{OH}, \mathrm{R}_{5}=\mathrm{OMe}, \mathrm{R}_{6}=\mathrm{OMe}$

$423 \mathrm{R}_{1}=\mathrm{H}, \mathrm{R}_{2}=\mathrm{OMe}, \mathrm{R}_{3}=\mathrm{OH}, \mathrm{R}_{4}=\mathrm{OMe}, \mathrm{R}_{5}=\mathrm{H}, \mathrm{R}_{6}=\mathrm{OMe}$ $424 R_{1}=H, R_{2}=O M e, R_{3}=O M e, R_{4}=O M e, R_{5}=H, R_{6}=O H$ $425 R_{1}=O H, R_{2}=$ OMe, $R_{3}=H, R_{4}=O M e, R_{5}=H, R_{6}=O M e$ $428 \mathrm{R}_{1}=\mathrm{H}, \mathrm{R}_{2}=\mathrm{OMe}, \mathrm{R}_{3}=\mathrm{OMe}, \mathrm{R}_{4}=\mathrm{OMe}, \mathrm{R}_{5}=\mathrm{H}, \mathrm{R}_{6}=\mathrm{OMe}$ $429 R_{1}=H, R_{2}=O H, R_{3}=O M e, R_{4}=O M e, R_{5}=H, R_{6}=O M e$ 
<smiles>COc1cc(O)c2c(=O)c(Cc3ccc(O)cc3)coc2c1</smiles><smiles>[R6]c1cc(C[C@]2(O)COc3cc(c(O)c([B])c3[R])C2=O)ccc1OC</smiles>

$404 \mathrm{R}_{1}=\mathrm{OMe}, \mathrm{R}_{2}=\mathrm{OMe}, \mathrm{R}_{3}=\mathrm{H}, \mathrm{R}_{4}=\mathrm{OMe}$ $405 \mathrm{R}_{1}=\mathrm{H}, \mathrm{R}_{2}=\mathrm{OMe}, \mathrm{R}_{3}=\mathrm{H}, \mathrm{R}_{4}=\mathrm{OMe}$ $406 \mathrm{R}_{1}=\mathrm{OMe}, \mathrm{R}_{2}=\mathrm{OMe}, \mathrm{R}_{3}=\mathrm{H}, \mathrm{R}_{4}=\mathrm{OH}$ $407 \mathrm{R}_{1}=\mathrm{H}, \mathrm{R}_{2}=\mathrm{OMe}, \mathrm{R}_{3}=\mathrm{OH}, \mathrm{R}_{4}=\mathrm{OH}$ $408 R_{1}=H, R_{2}=O H, R_{3}=H, R_{4}=O H$<smiles>[R]c1cc(/C=C/c2ccc([B])cc2)ccc1P</smiles>

$413 \mathrm{R}_{1}=\mathrm{OH}, \mathrm{R}_{2}=\mathrm{H}, \mathrm{R}_{3}=\mathrm{OH} \quad 415 \mathrm{R}_{1}=\mathrm{OH}, \mathrm{R}_{2}=\mathrm{OMe}, \mathrm{R}_{3}=\mathrm{OMe}$ $414 \mathrm{R}_{1}=\mathrm{OMe}, \mathrm{R}_{2}=\mathrm{OH}, \mathrm{R}_{3}=\mathrm{OH} \quad 416 \mathrm{R}_{1}=\mathrm{OMe}, \mathrm{R}_{2}=\mathrm{H}, \mathrm{R}_{3}=\mathrm{OH}$ $426 \mathrm{R}_{1}=\mathrm{OH}, \mathrm{R}_{2}=\mathrm{OMe}, \mathrm{R}_{3}=\mathrm{OMe}$ $427 \mathrm{R}_{1}=\mathrm{OH}, \mathrm{R}_{2}=\mathrm{OMe}, \mathrm{R}_{3}=\mathrm{OH}$ homoisoflavanones, all as racemic mixtures (404-408) as well as the spirocyclic nortriterpenoid, 15-deoxoeucosterol. ${ }^{167}$ A subsequent study on the bulbs of Pseudoprospero firmifolium subsp. natalensis J.C. Manning confirmed the previous findings for the typical subspecies but, in addition, found the homoisoflavanone 59 in the dichloromethane extract. ${ }^{42}$

Schizocarphus nervosus (Burch.) van der Merwe is widespread in southern Africa. Although toxic to livestock, ${ }^{\mathbf{1}}$ it plays an important role in traditional medicine within the region. The bulbs are used by the Zulu to treat dysentery and nervous conditions in children as well as treat rheumatic fever. ${ }^{168}$ In Botswana the bulbs are used to enhance fertility and to treat infections. ${ }^{169}$ The methanol extract of the bulbs of S. nervosus (as Scilla nervosa (Burch.) Jessop) has been tested for anti-inflammatory and anti-microbial activity. The crude methanol extract displayed a strong, but short-acting effect on a croton-oil induced contact dermatitis in a mouse ear $(66 \%$ reduction of oedema after $3 \mathrm{~h}$ ) and the nonpolar components were active against Staphylococcus aureus $\left(\mathrm{IC}_{50}=1.8 \mu \mathrm{g} \mathrm{ml}{ }^{-1}\right)$, Klebsiellia pneumonia $\left(\mathrm{IC}_{50}=2.0 \mu \mathrm{g} \mathrm{ml}{ }^{-1}\right)$ and Candida albicans $\left(\mathrm{IC}_{50}=\right.$ $1.0 \mu \mathrm{g} \mathrm{ml}^{-1}$ ). Little discrimination was noted between the Grampositive and Gram-negative bacteria, but some specificity for the yeast was observed. ${ }^{169}$ Five homoisoflavanones (49 and 409-412) and two stilbenoids $(\mathbf{4 1 3}, \mathbf{4 1 4})$ have been isolated from the bulbs. ${ }^{168}$ A further thirteen homoisoflavanones (41, 49 and 415425) and three stilbenes (414 and 426-427) have been isolated from the bulbs of $S$. nervosus (as Scilla nervosa (Burch.) Jessop subsp. rigidifolia). ${ }^{170,171}$ Compound $\mathbf{4 1 9}$ was found to be highly active against colon cancer (HT-29 cell line $\mathrm{ED}_{50}=0.88 \mu \mathrm{g} \mathrm{ml}^{-1}$ ) and breast cancer (MDA-MB-435 cell line $\left.\mathrm{ED}_{50}=0.42 \mu \mathrm{g} \mathrm{ml}{ }^{-1}\right) \cdot{ }^{170}$ The yellow inter-bulbscale deposits of this subspecies were likewise investigated and eight homoisoflavanones were isolated, two of which were novel (428-429). ${ }^{172}$ There has been some evidence presented to indicate that the bulbs may cause damage to liver cells. ${ }^{173}$ A homoisoflavanone $\mathbf{4 0 0}$ has been isolated from Spetaea lachenaliiflora Wetschnig \& Pfosser (as Scilla plumbea Lindl.). This is a little known species, neither toxic nor known to be used by traditional healers. ${ }^{65}$

\section{The Urgineoideae}

The subfamily Urgineoideae, with more than 100 species, ${ }^{7}$ has received considerable taxonomic attention in recent years, with widely differing opinions subsequently offered on generic circumscriptions. Speta recognised eleven genera, ${ }^{174}$ several of which have been studied from both a phytochemical and a pharmacological perspective. More than any other compound type, the bufadienolides characterise the Urgineoideae. Bufadienolides are $\mathrm{C}-24$ steroids possessing an $\alpha$-pyrone group (doubly unsaturated six-membered lactone ring) at position $17 \beta$. The presence of these highly toxic cardioactive steroids has led to these plants being used by man in antiquity, with the ancient Egyptians reportedly using preparations to treat heart disease. ${ }^{175}$ Research into this subfamily was further stimulated by the sometimes fatal toxicity associated with various species, both to stock ${ }^{176-178}$ and to humans. ${ }^{179,180}$ The systematic position of the sea onion, Charydbis maritima (L.) Speta, has long been debated. ${ }^{181}$ The ancient Greeks referred to the plant as skilla, the Romans as scilla and for much of the early research on this plant, the names Urginea maritima or Scilla maritima were applied. Subsequent work by Pfosser and Speta ${ }^{181}$ provided evidence for two genera in the subfamily Urgineoideae in the Mediterranean region, Urginea Steinh. and Charydbis Speta. Phytochemical investigations to date support this generic distinction.

With much of the early research on Charybdis maritima focused on the plant then known as Scilla maritima, the trivial names of isolates of this urgineoid accordingly reflect this nomenclatural association. Notably, Scilla is a distinct genus currently assigned to the subfamily Hyacinthoideae, and has a very different chemical profile. Kopaczewski isolated a toxic component from the bulbs of C. maritima (as Scilla maritima) which he termed scillitin. ${ }^{182}$ It was found to be a diuretic but the whole extract from the bulbs was found to be more poisonous to guinea pigs and rabbits than scillitin itself. ${ }^{183}$ In contrast, Smith found scillitin to be more toxic to rats than the crude extract. ${ }^{184}$ The bufadienolides scillaren A 224, scilliroside 430, proscillaridin A 223 and scillaren F $\mathbf{4 3 1}$ have also been isolated from C. maritima (reported as Scilla maritima and/or Urginia maritima) $\cdot{ }^{185-190}$ Using HPLC, with proscillaridin A 223 as a reference, Tittel and Wagner showed the possible presence of bufadienolides in a plant identified as Scilla rubra L. (here considered synonymous with C. maritima) ${ }^{191}$ Petrol extracts of bulbs of this species (as Scilla maritima and Urginia maritima) were found to contain fatty acids (lauric acid, myristic acid, 


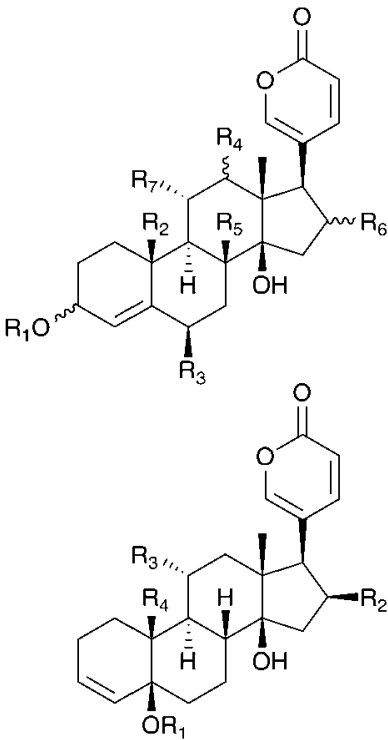

$223: \mathrm{R}_{1}=\alpha$-L-rhamnopyranoside, $\mathrm{R}_{2}=\mathrm{CH}_{3}, \mathrm{R}_{3}-\mathrm{R}_{7}=\mathrm{H}$

$224 \mathrm{R}_{1}=\alpha$-L-rhamnopyranosyl- $(1 \rightarrow 4)$ - $\beta$-D-glucopyranoside, $\mathrm{R}_{2}=\mathrm{CH}_{3}, \mathrm{R}_{3}-\mathrm{R}_{7}=\mathrm{H}$

$430: R_{1}=\beta$-D-glucopyranoside, $R_{2}=C_{3}, R_{3}=O A C, R_{4}=H, R_{5}=O H, R_{6}=H, R_{7}=H$

$433: R_{1}=\beta$-D-glucopyranoside, $R_{2}=\mathrm{CH}_{3}, \mathrm{R}_{3}-\mathrm{R}_{7}=\mathrm{H}$

$435: R_{1}=\beta$-D-glucopyranosyl- $(1 \rightarrow 4)-\beta$-D-glucopyranosyl-(1 $\left.\rightarrow 4\right)-\alpha$-L-rhamnopyranoside, $\mathrm{R}_{2}=\mathrm{CH}_{3}, \mathrm{R}_{3}-\mathrm{R}_{7}=\mathrm{H}$

$436: R_{1}=\alpha$-L-rhamnopyranoside, $R_{2}=C_{3}, R_{3}=H, R_{5}=H, R_{6}=H, R_{4}=\alpha-O H, R_{7}=H$

$437: R_{1}=\beta$-D-glucopyranosyl- $(1 \rightarrow 4)$ - $\alpha$-L- rhamnopyranoside, $R_{2}=C_{3}, R_{3}=H R_{5}=H, R_{6}=H, R_{4}=\alpha-O H$

$449 \mathrm{R}_{1}=\alpha$-L-rhamnopyranoside, $\mathrm{R}_{2}=\mathrm{CHO}, \mathrm{R}_{3}-\mathrm{R}_{6}=\mathrm{H}, \mathrm{R}_{7}=\mathrm{OH}$

$488 R_{1}=\beta$-D-glucopyranoside, $R_{2}=C H O, R_{3}=H_{1} R_{4}=\beta-O H, R_{5}-R_{7}=H$

\begin{abstract}
$431 \mathrm{R}_{1}=\beta$-D-glucopyranoside, $\mathrm{R}_{2}=\mathrm{H}, \mathrm{R}_{3}=\mathrm{H}, \mathrm{R}_{4}=\mathrm{CHO}$
$434 \mathrm{R}_{1}=\beta$-D-glucopyranoside, $\mathrm{R}_{2}=\mathrm{OAc}, \mathrm{R}_{3}=\mathrm{H}, \mathrm{R}_{4}=\mathrm{CHO}$

$478 R_{1}=\beta$-D-glucopyranoside, $R_{2}=H, R_{3}=O H, R_{4}=C H O$

$493 R_{1}=\beta$-D-glucopyranoside, $R_{2}=H, R_{3}=H R_{4}=C O O H$
\end{abstract}

$494 \mathrm{R}_{1}=\mathrm{H}, \mathrm{R}_{2}=\mathrm{H}, \mathrm{R}_{3}=\mathrm{H}, \mathrm{R}_{4}=\mathrm{CHO}$

palmitic acid, palmitoleic acid, stearic acid, oleic acid, linoleic acid and linolenic acid) and sterols (sitosterol, stigmasterol, campesterol and cholesterol). ${ }^{192-194}$

Investigations carried out in the early 1920s focused primarily on Charydbis maritima (squill). Both the extracts of fresh bulbs and dried powdered bulbs showed digitalis-like activity on the heart when tested on frogs and cats. ${ }^{195,196}$ Markwalder ${ }^{196}$ found no difference in activity between the fresh and dried bulbs and noted that neither the dried outer leaves nor the heart of the bulb exhibited much activity, while the mature middle layers of the bulb were rich in active components. The structure of scillaren A 224, the principle active component of $C$. maritima (reported as Urginia maritima) was elucidated by Stoll et al. in $1933 .{ }^{197}$ The interesting activity shown by the squill bufadienolides resulted in some comparative studies with digitoxigenin and strophanthidin as well as the effects of combination therapy. ${ }^{198,199}$ Extensive work on the bulbs of $C$. maritima (as Urginia maritima) over the following years resulted in the isolation and identification of a large number and variety of bufadienolides. They can be divided into those having a double bond at C-4 (e.g., 224), those having a double bond at C-3 (e.g., 431) and those without either (dihydro C-4) (e.g., 432). Without exception, within C. maritima they contain a $\beta$-hydroxy group at C-14, a trans junction of rings $\mathrm{B}$ and $\mathrm{C}$ and a cis junction of rings $\mathrm{C}$ and $\mathrm{D}$. They have been isolated as the aglycones as well as a variety of glycosides, with scillaren A $\mathbf{2 2 4}$ and proscillaridin A 223 being present in all specimens of C. maritima investigated. Samples of the plant from across its Mediterranean, European and Middle Eastern range have been investigated and this would account for the great diversity of bufadienolides isolated.

Von Wartburg and Renz ${ }^{200,201}$ isolated five bufadienolides from C. maritima (as Urginia maritima), scilliroside 430, scillaren A 224, scillaren F 431, proscillaridin A 223 and scillarenin- $\beta$-D-glucopyranoside 433 . The structures reported at that time were subsequently revised and the structures shown here reflect that revision. ${ }^{202,203}$ Gorlich $^{204}$ found proscillaridin A 223, scillaren A 224, scilliglaucoside (scillaren F) 431 and scillicyanoside $\mathbf{4 3 4}$ in crystalline form as well as minor amounts of scillicoeloside (no structure given) and glucoscillaren A 435. Later work on this plant resulted in the isolation of further minor components, scilliphaeoside $\mathbf{4 3 6}$ and glucoscilliphaeoside $437 .{ }^{205} \mathrm{~A}$ reinvestigation of the bulbs of C. maritima (as Urginia maritima) in 1991 by Krenn et al. ${ }^{206}$ resulted in an additional four new bufadienolides, identified as 5 $5-4,5$-dihydroproscillaridin A 432, 5 $\alpha$-4,5-dihydroglucoscillaren A 438,

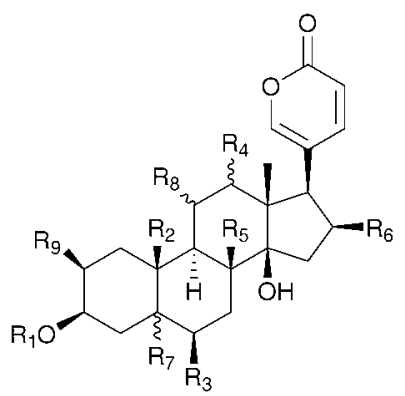

$432 \mathrm{R}_{1}=\alpha$-L-rhamnopyranoside, $\mathrm{R}_{2}=\mathrm{CH}_{3} \mathrm{R}_{3}-\mathrm{R}_{9}=\mathrm{H}, \mathrm{R}_{7}=\alpha-\mathrm{H}$

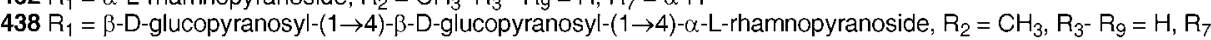
$=\alpha-\mathrm{H}$

$439 \mathrm{R}_{1}=\alpha$-L- rhamnopyranosyl- $\beta$-D-glucopyranoside, $\mathrm{R}_{2}=\mathrm{CH}_{3}, \mathrm{R}_{3}-\mathrm{R}_{6}=\mathrm{H}, \mathrm{R}_{7}=\beta-\mathrm{H}, \mathrm{R}_{8}=\alpha-\mathrm{OH}, \mathrm{R}_{9}=\mathrm{H}$ $440 \mathrm{R}_{1}=\alpha$-L-rhamnopyranoside, $\mathrm{R}_{2}=\mathrm{CHO} \mathrm{R}_{3}-\mathrm{R}_{6}=\mathrm{H}, \mathrm{R}_{7}=\alpha-\mathrm{H}, \mathrm{R}_{8}=\mathrm{H}, \mathrm{R}_{9}=\mathrm{H}$

$477 R_{1}=\alpha$-L- rhamnopyranosyl- $\beta$-D-glucopyranoside, $R_{2}=C_{3}, R_{3}-R_{6}=H, R_{7}=\beta-H R_{8}=\alpha-O A c, R_{9}=H$ $490 \mathrm{R}_{1}=\alpha$-L-rhamnopyranoside, $\mathrm{R}_{2}=\mathrm{CH}_{3}, \mathrm{R}_{3}=\mathrm{H}, \mathrm{R}_{4}=\mathrm{H}, \mathrm{R}_{5}=\mathrm{H}, \mathrm{R}_{6}=\mathrm{H}, \mathrm{R}_{7}=\mathrm{H}, \mathrm{R}_{8}=\alpha-\mathrm{OH}, \mathrm{R}_{9}=\mathrm{H}$ 
gamabufotalin-3-O- $\alpha$-L-rhamnopyranosyl- $\beta$-D-glucopyranoside 439 and 19-oxo-5 $\alpha-4,5$-dihydroproscillaridin A 440. Forty-one bufadienolides were isolated from an Egyptian sample of $C$. maritima (as Urginia maritima). ${ }^{207}$ Proscillaridin A 223, scillaren A 224 and scilliroside 430 were found as expected. In addition to 15 known bufadienolides found (223, 224, 430, 434, 435, 436, 441-449), 10 new glucosides of known aglycones (450-459) and sixteen new compounds were isolated (460-475). An unusual 9-hydroxy bufadienolide 476 was later isolated, also from Egyptian material. ${ }^{208}$
From 2000 until 2012 a total of eleven additional new bufadienolides (477-487) have been isolated from C. maritima (as Urginia maritima). Two of the compounds 477 and 478 were isolated from Spanish material ${ }^{209}$ and nine (479-487) from a plant cultivated in Japan (provenance undisclosed). ${ }^{\mathbf{2 1 0}}$ A comparative study of the bulbs of $C$. maritima collected in the northern and southern regions of the Mediterranean area showed some differences in both the quantity and type of bufadienolides isolated. ${ }^{\mathbf{2 1 1}}$ Both samples contained scilliroside 430, scillarenin

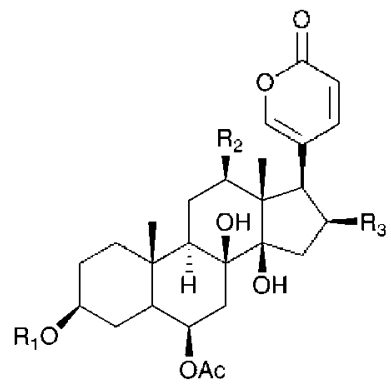

$447 \mathrm{R}_{1}=\alpha-\mathrm{L}$-thevetopyranosyl-(1 $\left.\rightarrow 4\right)-\beta$-D-glucopyranoside, $\mathrm{R}_{2}=\mathrm{H}_{2} \mathrm{R}_{3}=\mathrm{H}$

$448 \mathrm{R}_{1}=a$-L-thevetopyranosyl-(1" $\left.\rightarrow 4^{\prime}\right)-\beta$-D-glucopyranosyl-(1"' $\left.\rightarrow 4^{\prime \prime}\right)-\left(\beta\right.$-D-glucopyranoside, $\mathrm{R}_{2}=\mathrm{H}, \mathrm{R}_{3}=\mathrm{H}$

$453 \mathrm{R}_{1}=\alpha$-L-glucomethylopyranoside, $\mathrm{R}_{2}=\mathrm{H}, \mathrm{A}_{3}=\mathrm{H}$

$454 R_{1}=\alpha$-L-thevetopyranoside, $R_{2}=H, R_{3}=H$

$455 R_{1}=\beta$-D-glucopyranoside, $R_{2}=H, R_{3}=H$

$456 \mathrm{R}_{1}=\alpha$-L-rhamnopyranosyl- $(1>4)-\beta$-D-glucopyranoside, $\mathrm{R}_{3}=\mathrm{H}_{1} \mathrm{R}_{3}=\mathrm{H}$

$457 R_{1}=u$-L-glucomethylopyranosyl-(1 $\left.\rightarrow 4\right)$ - $\beta$-D-glucopyranoside, $R_{2}=H, R_{3}=H$

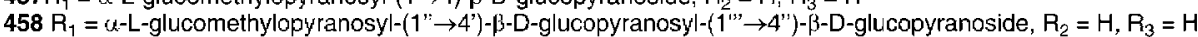

$459 \mathrm{R}_{1}=a$-L-rhamnopyranosyl-(1" $\left.\rightarrow 4^{\prime}\right)$ - $\left[3\right.$-D-glucopyranosyl- $\left(1^{\prime \prime \prime} \rightarrow 4^{\prime \prime}\right)$ - $\left(3\right.$-D-glucopyranoside, $\mathrm{R}_{2}=\mathrm{H}, \mathrm{R}_{3}=\mathrm{H}$

$472 \alpha$-L-thevetopyranoside, $R_{2}=O H, R_{3}=H$

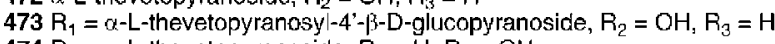

$474 \mathrm{R}_{1}=\alpha$-L-thevetopyranoside, $\mathrm{R}_{2}=\mathrm{H}, \mathrm{R}_{3}=\mathrm{OH}$

$475 \mathrm{R}_{1}=\alpha$-L-thevetopyranosyl-4'- $\beta$-D-glucospyranoide, $\mathrm{R}_{2}=\mathrm{H}_{1} \mathrm{R}_{3}=\mathrm{OAc}$

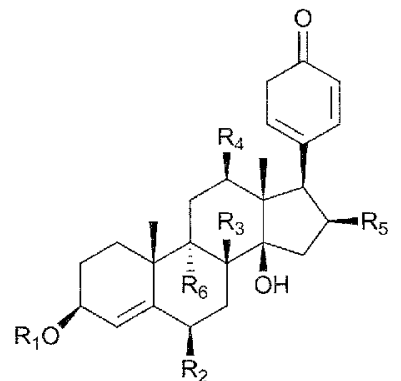

$441 \mathrm{R}_{1}=\beta$-D-glucopyranoside, $\mathrm{R}_{2}=\mathrm{H}, \mathrm{R}_{3}=\mathrm{H}_{1} \mathrm{R}_{4}=\mathrm{OH}, \mathrm{R}_{5}=\mathrm{H}, \mathrm{R}_{6}=\mathrm{H}$

$442 R_{1}=\alpha$-L-rhamnopyranosyl- $\beta$-D-glucopyranoside, $R_{2}=H . R_{3}=H_{1} R_{4}=O H, R_{5}=H_{1} R_{6}=H$

$443 \mathrm{R}_{1}=\beta$-D-glucopyranoside, $\mathrm{R}_{2}=\mathrm{OH}, \mathrm{R}_{3}=\mathrm{OH}, \mathrm{R}_{4}=\mathrm{H}, \mathrm{R}_{5}=\mathrm{H}_{1} \mathrm{R}_{6}=\mathrm{H}$

$444 R_{1}=-\beta$ - D-glucopyranosyl-(1" $\left(1^{\prime \prime} \rightarrow 4^{\prime}\right)-\beta-D-$-glucopyranoside, $R_{2}=O A C, R_{3}=O H, R_{4}=H, R_{5}=H, R_{6}=H$

$445 \mathrm{R}_{1}=\mathrm{H}, \mathrm{R}_{2}=\mathrm{OAC}, \mathrm{R}_{3}=\mathrm{OH}, \mathrm{R}_{4}=\mathrm{OH}, \mathrm{R}_{5}=\mathrm{H}, \mathrm{R}_{6}=\mathrm{H}$

$446 \mathrm{R}_{1}=\beta$-D-glucopyranoside, $\mathrm{R}_{2}=\mathrm{OAc}, \mathrm{R}_{3}=\mathrm{OH}, \mathrm{A}_{4}=\mathrm{OH}, \mathrm{R}_{5}=\mathrm{H}, \mathrm{R}_{6}=\mathrm{H}$

$450 R_{1}=\beta$-D-glucopyranosyl-(1" $\left.\rightarrow 4^{\prime}\right)$ - $\beta$-D-glucopyranoside, $R_{2}=H, R_{3}=H, R_{4}=H, R_{5}=H_{1} R_{6}=H$

$451 R_{1}=\beta$-D-glucopyranosyl-(1" $\left.\rightarrow 4^{\prime}\right)-\beta$-D-glucopyranoside, $R_{2}=H, R_{3}=O H, R_{4}=H, R_{5}=H, R_{6}=H$

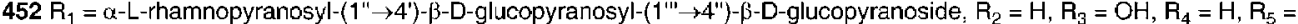

$\mathrm{H}, \mathrm{R}_{\mathrm{6}}=\mathrm{H}$

$460 \mathrm{R}_{1}=\beta$-D-glucopyranoside, $\mathrm{R}_{2}=\mathrm{OH}, \mathrm{R}_{3}=\mathrm{OH}, \mathrm{R}_{4}=\mathrm{OH}, \mathrm{R}_{5}=\mathrm{H}, \mathrm{R}_{6}=\mathrm{H}$

$461 R_{1}=a$-L-hamnopyranoside, $R_{2}=H, R_{3}=O H, R_{4}=O H, R_{5}=H, R_{6}=H$

$462 \mathrm{R}_{1}=\alpha$-L-rhamnopyranoside, $\mathrm{R}_{2}=\mathrm{H}, \mathrm{R}_{3}=\mathrm{H}_{1} \mathrm{R}_{4}=\mathrm{H}, \mathrm{R}_{5}=\mathrm{OH}, \mathrm{R}_{6}=\mathrm{H}$

$463 \mathrm{R}_{1}=\beta$-D-glucopyranoside, $\mathrm{R}_{2}=\mathrm{H}, \mathrm{R}_{3}=\mathrm{H}_{1} \mathrm{R}_{4}=\mathrm{H}, \mathrm{R}_{5}=\mathrm{OH}, \mathrm{R}_{6}=\mathrm{H}$

$464 R_{1}=\alpha$-L-rhamnopyranosyl- $\left(1^{\prime \prime} \rightarrow 4^{\prime}\right)-\beta$-D-glucopyranosyl-(1'" $\left.\rightarrow 4^{\prime \prime}\right)-\beta$-D-glucopyranoside, $R_{2}=H, R_{3}=H, R_{4}=H, R_{5}=$

$\mathrm{OH}, \mathrm{R}_{6}=\mathrm{H}$

$465 \mathrm{R}_{1}=\alpha$-L-rhamnopyranoside, $\mathrm{R}_{2}=\mathrm{H}, \mathrm{R}_{3}=\mathrm{H}, \mathrm{R}_{4}=\mathrm{H}, \mathrm{R}_{5}=\mathrm{OAc}, \mathrm{R}_{6}=\mathrm{H}$

$466 R_{1}=-\beta$-D-glucopyranoside, $R_{2}=H, R_{3}=H_{1} R_{4}=H, R_{5}=O A c_{1}, R_{6}=H$

$467 R_{1}=-\beta$-D-glucopyranosyl- $\left(1^{\prime \prime} \rightarrow 4^{\prime}\right)$-glucopyranoside, $R_{2}=H_{1} R_{3}=H_{1}, R_{4}=H, R_{5}=O A c, R_{6}=H$

$468 \mathrm{R}_{1}=\alpha$-L-rhamnopyranosyl-(1" $\left.\rightarrow 4^{\prime}\right)$ - $\beta$-D-glucopyranosyl-(1'" $\left.\rightarrow 4^{\prime \prime}\right)-\beta$-D-glucopyranoside, $\mathrm{R}_{2}=\mathrm{H}, \mathrm{R}_{3}=\mathrm{H}, \mathrm{R}_{4}=\mathrm{H}, \mathrm{R}_{5}=$

$\mathrm{OAc}, \mathrm{P}_{6}=\mathrm{H}$

$469 R_{1}=\alpha$-L-glucomethylopyranosyl-(1" $\left.\rightarrow 4^{\prime \prime}\right)$ - $\beta$-D-glucopyranosyl-(1'" $\left.\rightarrow 4^{\prime \prime}\right)-\beta$-D-glucopyranoside, $R_{2}=H, R_{3}=H, R_{4}=H, R_{5}$

$=\mathrm{OAC}, \mathrm{R}_{6}=\mathrm{H}$

$470 \mathrm{R}_{1}=$ B-D-glucopyranoside, $\mathrm{R}_{2}=\mathrm{H}, \mathrm{R}_{3}=\mathrm{OH}, \mathrm{R}_{4}=\mathrm{H}, \mathrm{R}_{5}=\mathrm{OAc}, \mathrm{R}_{6}=\mathrm{H}$

$471 R_{1}=\alpha$-L-rhamnopyranoside, $R_{2}=H, R_{3}=H, R_{4}=O H, R_{5}=H, R_{6}=O H$ 


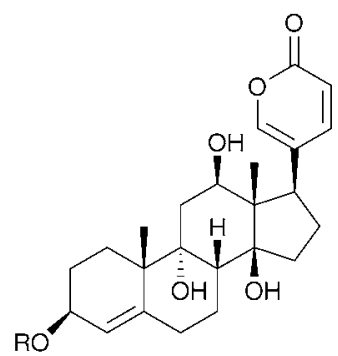

$476 R=\alpha$-L-rhamnopyranoside

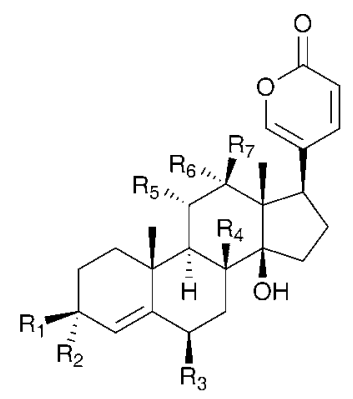

$479 \mathrm{R}_{1}=\mathrm{OH}, \mathrm{R}_{2}=\mathrm{OCH}_{3}, \mathrm{R}_{3}=\mathrm{H}, \mathrm{R}_{4}=\mathrm{H}, \mathrm{R}_{5}=\mathrm{H}, \mathrm{R}_{6}=\mathrm{H}, \mathrm{R}_{7}=\mathrm{OH}$

$480 R_{1}==\mathrm{O}, \mathrm{R}_{3}=\mathrm{H}, \mathrm{R}_{4}=\mathrm{H}, \mathrm{R}_{5}=\mathrm{OH}, \mathrm{R}_{6}=\mathrm{H}, \mathrm{R}_{7}=\mathrm{H}$

$481 \mathrm{R}_{1}=\mathrm{OH}, \mathrm{R}_{2}=\mathrm{OH}, \mathrm{R}_{3}=\mathrm{H}, \mathrm{R}_{4}=\mathrm{H}, \mathrm{R}_{5}=\mathrm{H}, \mathrm{R}_{6}=\mathrm{OH}, \mathrm{R}_{7}=\mathrm{H}$

$482 \mathrm{R}_{1}=-\mathrm{O}$ - $\beta$-D-glucopyranoside, $\mathrm{R}_{2}=\mathrm{H}_{1} \mathrm{R}_{3}=\mathrm{OAC}, \mathrm{R}_{4}=\mathrm{H}_{1} \mathrm{R}_{5}=\mathrm{H}_{1}, \mathrm{R}_{6}=\mathrm{H}_{1} \mathrm{R}_{7}=\mathrm{H}$

$483 R_{1}=-O-\alpha$-L-rhamnopyranosyl-(1 $\left.\rightarrow 4\right)-\beta$-D-glucopyranoside, $R_{2}=H, R_{3}=\mathrm{OAc}, \mathrm{R}_{4}=\mathrm{H}, \mathrm{R}_{5}=\mathrm{H}, \mathrm{R}_{6}=\mathrm{H}, \mathrm{R}_{7}=\mathrm{H}$

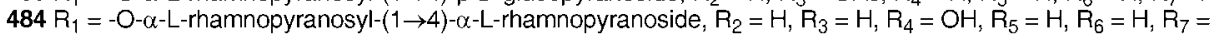

$485 R_{1}=-O-\alpha$-L-rhamnopyranosyl-(1 $\left.\rightarrow 4\right)-\beta$-D-glucopyranoside, $R_{2}=H, R_{3}=O A c, R_{4}=O H, R_{5}=H, R_{6}=H, R_{7}$ $=\mathrm{H}$

$486 R_{1}=-O-3^{\prime}-O A C-\alpha$-L-rhamnopyranosyl-(1 $\left.\rightarrow 4\right)$ - $\beta$-D-glucopyranoside, $R_{2}=H, R_{3}=H, R_{4}=H, R_{5}=H, R_{6}=H$, $\mathrm{R}_{7}=\mathrm{H}$

$487 R_{1}=-O-2 '-O A C-\alpha$-L-rhamnopyranosyl-(1 $\left.\rightarrow 4\right)-\beta$-D-glucopyranoside, $R_{2}=H, R_{3}=H, R_{4}=H, R_{5}=H, R_{6}=H$, $\mathrm{R}_{7}=\mathrm{H}$

$489 \mathrm{R}_{1}=-\mathrm{O}-\alpha$-L-rhamnopyranosyl- $\alpha$-L-rhamnopyranoside, $\mathrm{R}_{2}=\mathrm{H}, \mathrm{R}_{3}=\mathrm{H}, \mathrm{R}_{4}=\mathrm{H}, \mathrm{R}_{5}=\mathrm{H}, \mathrm{R}_{6}=\mathrm{OH}, \mathrm{R}_{7}=\mathrm{H}$

$491 \mathrm{R}_{1}=-\mathrm{O}-\alpha$-L-rhamnopyranoside, $\mathrm{R}_{2}=\mathrm{H}, \mathrm{R}_{3}=\mathrm{H}, \mathrm{R}_{4}=\mathrm{OH}, \mathrm{R}_{5}=\mathrm{H}, \mathrm{R}_{6}=\mathrm{H}, \mathrm{R}_{7}=\mathrm{H}$

$492 \mathrm{R}_{1}=-\mathrm{O}$ - $\beta$-D-glucopyranoside, $\mathrm{R}_{2}=\mathrm{H}, \mathrm{R}_{3}=\mathrm{H}, \mathrm{R}_{4}=\mathrm{OH}, \mathrm{R}_{5}=\mathrm{H}, \mathrm{R}_{6}=\mathrm{H}, \mathrm{R}_{7}=\mathrm{H}$

3-O- $\beta$-D-glucopyranoside 433, proscillaren A 223, scilliphaesidin 3$\beta$-D-glucopyranoside 441, scilliglaucoside 431, scilliphaoside 436 and 12-epi-scilliphaeoside. In addition, the bulbs from Tunisia contained glucoscilliphaeoside 437, 12-epi-glucoscilliphaeoside, 12ß-hydroxyscilliglaucosidin 3-O- $\beta$-D-glucopyranoside 488, 12-episcilliphaeosidin 3-O- $\beta$-D-glucopyranoside 443 and 12-epi-scilliphaeosidin 3-O- $\alpha$-L-rhamnopyranosyl- $\alpha$-L-rhamnopyrano- side 489. Bulbs sourced from Sardegna also contained gamabufotalin 3-O- $\alpha-$ L-rhamnopyranoside 490, scillirubrosidin 3-O- $\alpha$-L-rhamnopyranoside 491, scillirubroside 492, 12 $\beta$-hydroxyscilliroside 446, 5 $\alpha-4,5-$ dihydroscillirosidin 3 - $O$ - $\alpha$-L-thevetopyranosyl- $\beta$-D-glucopyranoside 475, deacetylscilliroside 443, 10-carboxy-5 $\beta$-14 $\beta$-hydroxybufa3,20,22-trienolide 5-O- $\beta$-D-glucopyranoside 493 and scilliglaucogenin 494.

The flavonoid, anthocyanin and sterol content of the bulbs of C. maritima (as Urginia maritima) have been investigated. The ethanol extract of the bulbs was studied by gas-liquid chromatography and the sterols identified by comparison to known reference compounds. Sitosterol, stigmasterol, campesterol, cholesterol, $\Delta^{5}$-avenasterol and $\Delta^{7}$-avenasterol were found to be present. ${ }^{193,194}$ Red bulbs of C. maritima (as Urginia maritima), collected in the Balearic Islands contained cyanidin 495, cyanidin-3-monoglucoside 496 and pelargonidin-3-monoglucoside 497, both in the free form and acylated with $p$-coumaric acid. ${ }^{212-216}$ The proportion of anthocyanin was found to be higher in tetraploids than in triploids or hexaploids. ${ }^{217}$

The flavonoids isolated included kaempferol-7-O- $\beta$-D-glucopyranoside-3-O- $\beta$-D-triglucopyranoside 498, kaempferol-7-O- $\beta$-Dglucopyranoside-3-O- $\alpha$-L-rhamnopyranosyl- $\beta$-D-glucopyranoside 499, kaempferol-7-O- $\beta$-D-glucopyranoside-3-O- $\beta$-D-diglucopyranoside 500 and kaempferol-7-O- $\alpha$-L-rhamnopyranoside-3- $O-\alpha-$ L-rhamnosyl- $\beta$-D-glucopyranoside $501 .^{218}$ In addition the

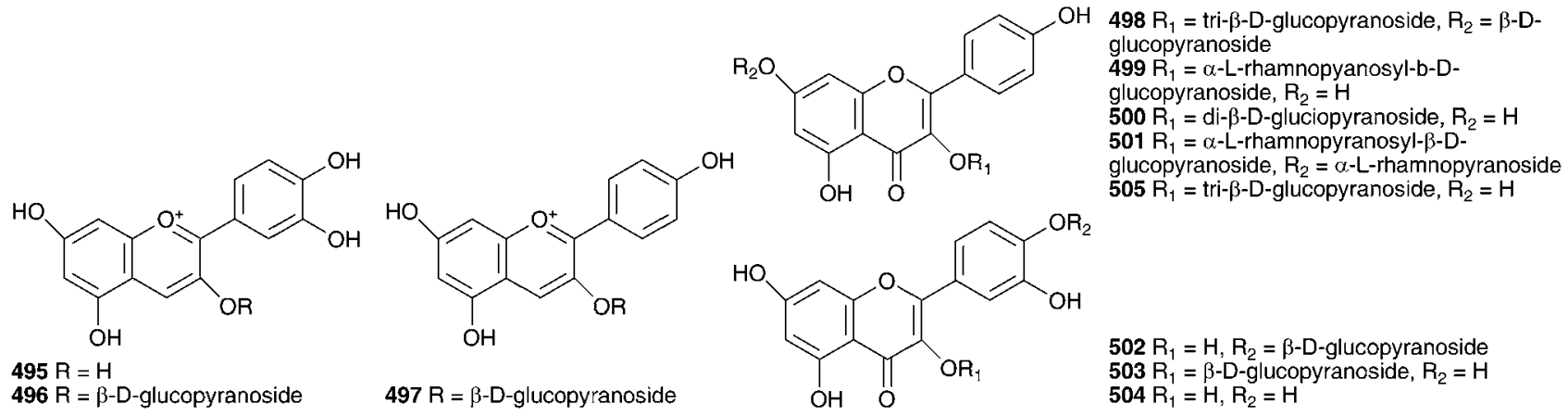


<smiles>[R]c1c(O)cc(O)c2c(=O)cc(-c3ccccc3)oc12</smiles><smiles>[2H]c1c(O)cc2oc(-c3ccc(O)c(O)c3)cc(=O)c2c1O</smiles><smiles>[2H]c1c(O)cc(O)c2c(=O)cc(-c3ccc(O)c(OC)c3)oc12</smiles>

$510 \mathrm{R}=\beta$-D-glucopyranoside<smiles>[R]c1cc(-c2cc(=O)c3c(O)c(O)c(O)cc3o2)ccc1O</smiles>

$511 R=\beta$-D-glucopyranoside

flavonoid O-glycosides 502-505, have been isolated. ${ }^{219}$ Five Cglycosylflavones have been isolated from the ethyl acetate extract of the bulbs. They have been identified as vitexin 506, isovitexin 507, orientin 508, isoorientin 509, scoparin 510 and isoscoparin 511. ${ }^{20-223}$ Fernandez et al. identified twenty-five flavonoids in a Spanish sample of C. maritima bulbs (as Urginia maritima). They followed a parallel series: pelargonidin, kaempferol, cyaniding, quercetin and taxifolin. A complex mixture of both C- and O-glycosides was obtained. ${ }^{224}$ A fructan, sinistrin, has been isolated from C. maritima (as Urginia maritima) and found to be a mixed type $\beta$-D-fructan, with (2-1) linked and (2-6) linked unbranched $\beta$-D-fructofuranosyl and $\alpha$ D-glucopyranoside residues. ${ }^{225,226}$

C. maritima (reported as Urginia maritima) has been used as a form of rodenticide since the 13 th century. ${ }^{202}$ The toxic component has been found to be scilliroside 430, which affects the cardiovascular and central nervous systems, resulting in death. ${ }^{202}$ Scilliroside has an emetic effect on humans, cats, dogs and pigeons, but rats and mice are unable to vomit and as such they die within a few hours of ingesting the bulbs. The flavonoid fraction has been found to have a diuretic effect ${ }^{227}$ and the ethanolic extract of Spanish squill has shown good insecticidal activity against the stored grain pest Tribolium castaneum (red flour beetle). ${ }^{228}$ Twelve wild populations of the bulbs were studied with the red bulbs giving 60-90\% mortality if applied at 20-30 $\mu \mathrm{g}$ insect $^{-1} \cdot{ }^{228}$ An extract of the bulbs of $C$. maritima (as Urginia maritima) growing in Turkey has been found to exhibit greater toxicity than cisplatin against the A549 non-small cell lung cancer (NSCLC) cell line. ${ }^{229}$ Tissue cultures of C. maritima (as Urginia maritima) grown both in the dark and under light showed no sign of the bufadienolides commonly associated with this species. The cultures grown in the light did though produce anthocyanins. ${ }^{230}$

The range of bufadienolides found in the bulbs of Charybdis hesperia (Webb \& Berthel.) Speta (as Urginea hesperia Webb \& Berthel.) indicates a close relationship to $C$. maritima. Thirteen bufadienolides have been isolated including scillarenin (512) and a variety of associated glycosides. ${ }^{231}$ Urginea fugax (Moris) Steinh. is a species which is widespread in the Mediterranean area. In contrast to $C$. maritima and $C$. hesperia, cardenolides

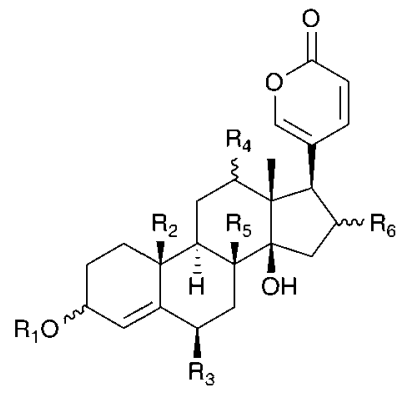

$512 \mathrm{R}_{1}=\mathrm{H}(\beta), \mathrm{R}_{2}=\mathrm{CH}_{3}, \mathrm{R}_{3}-\mathrm{R}_{6}=\mathrm{H}$

$518 R_{1}=H, R_{2}=C_{3}, R_{3}=O A C, R_{4}=H, R_{5}=O H, R_{6}=H$

$519 \mathrm{R}_{1}=\mathrm{H}, \mathrm{R}_{2}=\mathrm{CH}_{3}, \mathrm{R}_{3}=\mathrm{OH}, \mathrm{R}_{4}=\mathrm{H}, \mathrm{R}_{5}=\mathrm{OH}, \mathrm{R}_{6}=\mathrm{H}$

$520 R_{1}=\beta$-D-glucopyranoside, $R_{2}=C_{3}, R_{3}=O H, R_{4}=\beta-O H, R_{5}=O H, R_{6}=H$

$522 R_{1}==O, R_{2}=C_{3}, R_{3}=O A C, R_{4}=O H, R_{5}=O H, R_{6}=H$

$523 \mathrm{R}_{1}=\mathrm{O}, \mathrm{R}_{2}=\mathrm{CH}_{3}, \mathrm{R}_{3}=\mathrm{H}, \mathrm{R}_{4}=\mathrm{OH}, \mathrm{R}_{5}=\mathrm{OH}, \mathrm{R}_{6}=\mathrm{H}$

$532 R_{1}=H(\beta), R_{2}=C H O, R_{3}-R_{6}=H$

$533 \mathrm{R}_{1}=\mathrm{O}, \mathrm{R}_{2}=\mathrm{CHO}, \mathrm{R}_{3}-\mathrm{R}_{6}=\mathrm{H}$

$534 R_{1}=\alpha$-L-rhamnopyranoside, $R_{2}=C H O, R_{3}-R_{6}=H$

$535 R_{1}=\beta$-D-glucopyranoside, $R_{2}=\mathrm{CHO}, \mathbf{R}_{3}-\mathrm{R}_{6}=\mathrm{H}$

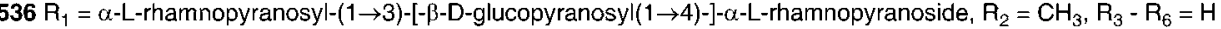

$546 R_{1}=H, R_{2}=C H O, R_{3}-R_{5}=H R_{6}=O A C$

$549 R_{1}=\alpha$-L-rhamnopyranoside, $R_{2}=C_{3}, R_{3}=H, R_{4}=O H, R_{5}-R_{6}=H$

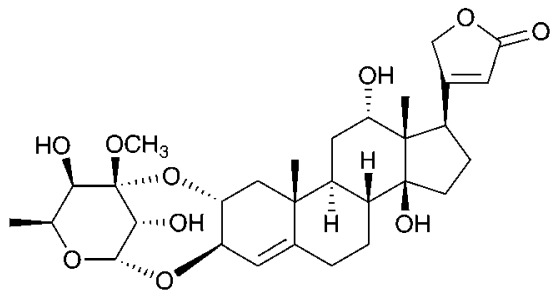

513 

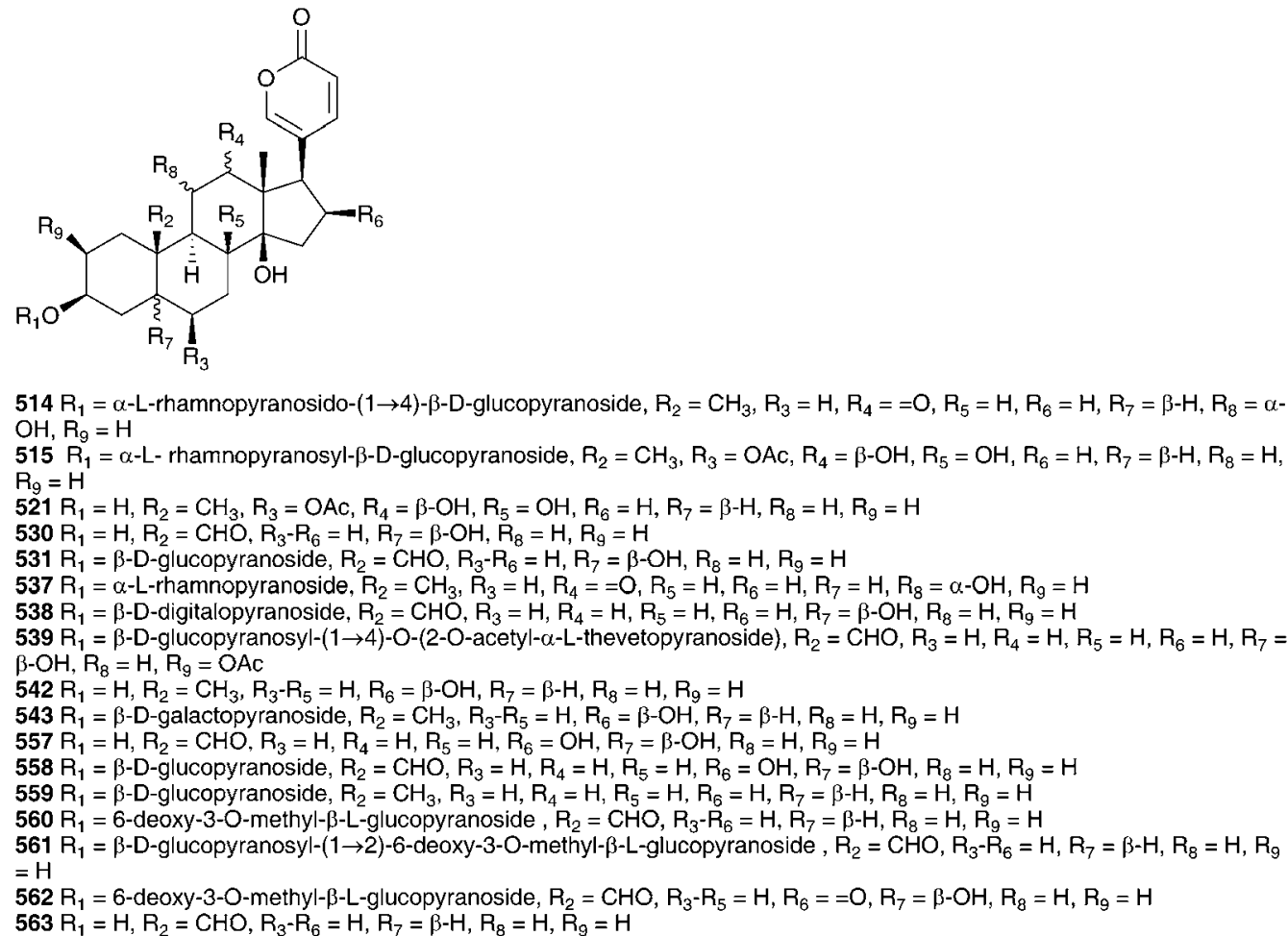

have been isolated from the bulbs. ${ }^{232}$ The new cardenolide fugaxin 513 has a rubellin-like carbohydrate linkage between C3 and C-2, unlike any seen in C. maritima and C. hesperia, which lends chemotaxonomic support to recognition of both Urginea and Charybdis in the Mediterranean region. ${ }^{181}$ Six bufadienoides have been isolated from the bulbs of Charybdis pancration (Steinh.) Speta (as Urginea pancration), scilliglaucoside 431, scillirubroside 492, scilliroside 430, 5 $\alpha$-4,5-dihydroscillirosidin 3-O- $\alpha$-L-thevetopyranosyl- $\beta$-D-glucopyranoside 475 , arenobufagin-3 $\beta$-O-L-rhamnopyranosyl-4'- $\beta$-D-glucopyranoside 514 and the glycoside 515. ${ }^{233,234}$ Charybdis aphylla (Forssk.) Speta (as Urginea aphylla (Forssk.) Speta), growing in the northeastern Mediterranean region was found to contain eleven bufadienolides, scillicyanoside 434, gamabufotalin-3-O- $\alpha$-L-rhamnopyranoside 490, scilliglaucoside 431, gamabufotalin-3-O- $\alpha-\mathrm{L}-$ rhamnosyl- $\beta$-D-glucopyranoside 439 , proscillaridin A 223 , scilliphaeosidin-3-O- $\beta$-D-glucopyranoside 437 , scillarenin-3- $O-\beta$-Dglucopyranoside $433,16 \beta$-O-acetylgamabufotalin-3-O- $\alpha$-L-rham-

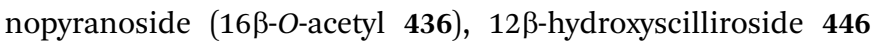
and $5 \alpha-4,5$-dihydroxyscillirosidin-3- $O$ - $\alpha$-L-thevetopyranosyl- $\beta$-Dglucopyranosyl- $\beta$-D-glucopyranoside $(475$ glucoside $) .{ }^{235}$ The similarity in chemical composition of the bulbs of Charybdis from across the European region highlights their close relationship.

As early as 1923, Juritz reported the presence of a glucoside in the toxic South Africa plant Boosia macrocentra (Baker) Speta (as Urginea macrocentra Baker) with digitalis-like activity and he noted that it could be used as a substitute for squill. ${ }^{236}$ This plant has also been implicated in stock mortality and it is used by the Zulu as a vermifuge (as Drimia macrocentra). ${ }^{237}$ The major component was identified as rubellin $\mathbf{5 1 6}$ by NMR spectroscopy. ${ }^{237}$ In 1927, work by Watt ${ }^{238}$ on South African Sekanama burkei (Baker) Speta (as Urginea burkei), yielded two glucosides, a red compound found to be toxic to animals and having a digitalis-like effect on the heart as well as a diuretic effect, and a white compound which resulted in paralysis of the central nervous system and respiration. Additional work on $S$. burkei (as Urginea burkei) and Urgineopsis modesta (Baker) Speta (as Urginea rubella Baker) in the 1940s and 1950s resulted in the isolation and identification of two cardiac glycosides, transvaalin and rubellin 516 respectively. ${ }^{239-243}$ Rubellin 516 was found to behave as a cardiac poison towards rats while transvaalin was found to kill rats primarily by its effect on the central nervous system. ${ }^{241,243,244}$ Rubellin was found to have a digitalislike action on cats. ${ }^{245}$ Further work by Louw et al. ${ }^{246}$ on transvaalin led to the conclusion that it was either isomeric with scillaren A $\mathbf{2 2 4}$ or a stable complex of scillaren A $\mathbf{2 2 4}$ and scilliroside 430. This was based on melting point analysis, toxicity tests and the fact that hydrolysis of transvaalin led to the same products as the hydrolysis of scillaren A, namely scillaridin A 517 and scillabiose (disaccharide). Zoller and Tamm $^{247}$ and Tschesehe and Hottemann ${ }^{240}$ all concluded that transvaalin and scillaren A were identical compounds. The structure of rubellin 516 was fully elucidated by Steyn et al. in $1986^{248}$ using high-field NMR spectroscopy. Later work by Krenn et al. ${ }^{249}$ on Sekanama sanguinea (Schinz) Speta (as Urginea sanguinea Schinz) yielded eight bufadienolides as well as a steroidal sapogenin and stigmasterol. The first six bufadienolides, namely scillirosidin $\mathbf{5 1 8}$,

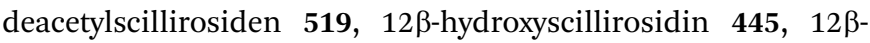
hydroxydeacetylscillirosidin 520, 12 $\beta$-hydroxyscilliroside 446 and $5 \alpha-4,5$-dihydro-12 $\beta$-hydroxyscillirosidin 521 had been isolated previously from other members of the Urgineoideae. Two 
new compounds, $12 \beta$-hydroxyscillirosidin-3-one 522 and $12 \beta$ hydroxyscillirubrosidin-3-one $\mathbf{5 2 3}$ were identified using NMR spectroscopy. The steroidal saponin, $7 \beta, 15 \alpha$-dihydroxyyamogenin $\mathbf{5 2 4}$ was the first such compound to be isolated from a member of the Urgineoideae. Majinda et al. ${ }^{250}$ investigated another specimen of the same plant, and found stigmasterol, phloroglucinol 525, phloroglucinol 1- $\beta-O$ glucopyranoside, scillaren A 224 and the novel 5 $\alpha$-4,5-dihydroscillaren A. In addition, salicylic acid and 3-hydroxy-4methylbenzoic acid were isolated. An ethnopharmacological study of S. sanguinea, using patient records from Ga-Rankuwa Hospital in South Africa revealed a number of cases of poisoning as a result of ingestion. The amount usually prescribed by traditional healers does not result in adverse side effects, but the patients admitted to the hospital had taken more than the prescribed dose. A brine shrimp assay showed a seasonal variation in toxicity, with the plant being more toxic in February (late Summer) than in September (Spring). ${ }^{251}$ Sekanama sanguinea has traditionally been used for many different conditions, including asthma and it is often taken by pregnant women. A study by Marx et al. ${ }^{252}$ (as Urginea sanguinea) showed significant damage to chick embryos after exposure to this plant. They concluded that it should be used with extreme care by traditional healers. ${ }^{253}$ Undoubtedly the bufadienolides dominate the chemistry of the Urgineoideae, including the Sekanama species. However, the isolation of a novel homoisoflavanoid from the bulbs of Sekanama delagoensis (Baker) Speta (as Drimia delagoensis (Baker) Jessop) indicates that a broader range of secondary metabolites can be expected, if not commonly found. ${ }^{254}$ The homoisoflavonoid 526 and 3-methoxy4-hydroxybenzoic acid 527, were isolated from the dichloromethane and methanol extracts of the bulbs respectively. ${ }^{254}$

Other sub-Saharan members of the Urgineoideae to receive attention include Urginavia altissima (L.f.) Speta (as Urginea altissima (L.f.) Baker and Drimia altissima (L.f.) Baker), Fusifilum physodes (Jacq.) Raf. ex Speta (as Urginea physodes (Jacq.) Baker),
Urginavia epigea (R.A.Dyer) Speta (as Urginea epigea R.A.Dyer), Urginea lydenburgensis R.A.Dyer and Urginea riparia Baker. Characteristic bufadienolides have been isolated and identified, many of which include either an aldehyde group at C-10 or a rubellin type carbohydrate group doubly linked to the aglycone at positions $2 \alpha$ and $3 \beta$. The best known of this group is the widespread Urginavia altissima (often referred to as Drimia altissima or Urginea altissima). Rat populations need to be controlled to limit threats to public health and minimise crop damage. The toxicity of $U$. altissima has been investigated with respect to the field rat, Arvicanthis abyssinicus. ${ }^{255}$ Synthetic rodenticides affect non-target species and can be expensive. The powdered bulb was tested and found to be toxic at levels of $5 \%$ of the daily food intake. If the percentage was lower, no mortality was noted. Urginavia brachystachys (Baker) Speta has (as Drimia brachystachys (Baker) Stedje) reportedly been used as an arrow poison. ${ }^{256}$

Both bufadienolides and alkaloids have been isolated from $U$. altissima. The alkaloids, lycorine $\mathbf{5 2 8}$ and acetylcaranine $\mathbf{5 2 9}$ have not been found by any subsequent investigators and the identity of the plant investigated by Miyakado and co-workers ${ }^{257}$ has been called into question as bulbs of $U$. altissima may be easily confused with those of some Amaryllidaceae, especially the genus Crinum L. ${ }^{258,259}$ Six bufadienolides have been isolated from $U$. altissima collected in Kenya, all of which have an aldehyde at C-10 (530-535). ${ }^{260,261}$ A South African sample of this plant was found to contain $12 \beta$-hydroxyscillirosidin $\mathbf{4 4 5},{ }^{258}$ which has been isolated from $S$. sanguinea previously and urginin 536 with an interesting trisaccharide substituent at C-3. ${ }^{258}$ A specimen from Ethiopia yielded different bufadienolides again, gamabufotalin-3-O- $\alpha-\mathrm{L}^{-}$ rhamnopyranoside 490 and arenobufagin-3- $O-\alpha$-L-rhamnopyranoside 537. ${ }^{259}$ It would appear that significant regional differences exist in the type of bufadienolide found in U. altissima. $U$. altissima is widely used for the treatment of gout, rheumatism and a number of respiratory conditions, including asthma. ${ }^{258}$ This plant is also used by Zimbabwean traditional healers to treat skin conditions. It has been found to produce a mild

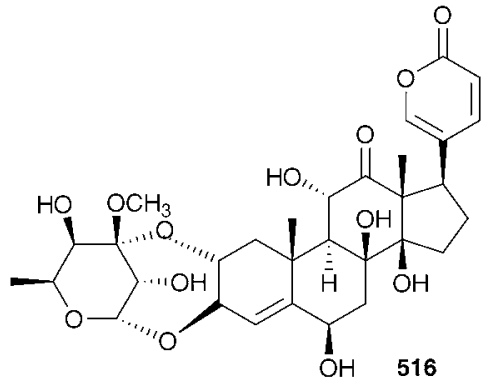<smiles>Oc1cc(O)cc(O)c1</smiles>

525

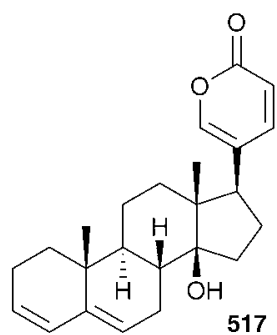

517<smiles>COc1cc(C(=O)O)ccc1O</smiles>

527
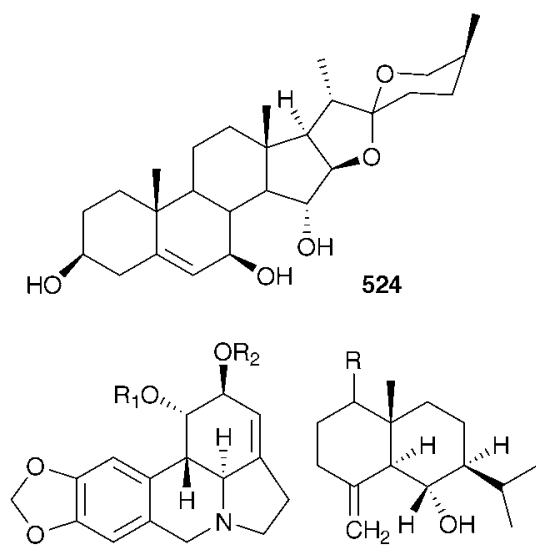

$528: R_{1}=H, R_{2}=O H$
$529: R_{1}=A c, R_{2}=H$

$\mathrm{R}=\mathrm{\beta}-\mathrm{OH}$

$548: R==0$ 
inflammation and itching if rubbed on the skin. This effect has been found to be due to the presence of calcium oxalate raphides in the bulbs and as such the appropriateness of its use as a skin treatment has been questioned. ${ }^{262}$

Fusifilum physodes (as Urginea physodes (Jacq.) Baker) was found to contain four bufadienolides, physodines A 538, B 539, C 540 and D 541. Two of which, physodines A and B, both having a C-10 aldehyde group, were found to be toxic to weaned guinea pigs (fractions not causing death in $48 \mathrm{~h}$ at $200 \mathrm{mg} \mathrm{kg}^{-1}$ were considered non toxic). Physodines $\mathrm{C}$ and $\mathrm{D}$ were of interest in that they were the first naturally occurring 14-deoxybufadienolides to be isolated. ${ }^{263}$ An ethanolic extract of the bulbs has been shown to have antifungal activity. ${ }^{264}$ The methanol extract of the bulbs of Fusifilum depressum (Baker) U.Müll.-Doblies J.S.Tang \& D.Müll.Doblies (as Drimia depressa (Baker) Jessop) was found to contain two bufadienolides, 542 and $\mathbf{5 4 3 .}{ }^{265}$ The leaves of this plant are toxic to cattle, sheep and rabbits and the plants are used by the Sotho as a good luck charm or to cause harm to one's enemy. ${ }^{265}$ Novel rubellin type bufadienolides, riparianin $\mathbf{5 4 4}$ and lydenburgenin 545, have been isolated from Urginea riparia and Urginea lydenburgensis R.A.Dyer respectively. ${ }^{237,266}$ In addition, Urginea lydenburgensis was found to contain the novel bufadienolide, scillicyanosidin 546, with an aldehyde group at C-10. Riparianin 544 showed moderate activity against MCF7 (breast), TK10 (renal) and UACC62 (melanoma) cell lines (total growth inhibition of $<3.5$, $<7$ and $<10.5$ ppm respectively). Urginavia epigea is used locally to treat backaches or as a soap. The smoke from smouldering bulbs is also used as a treatment for headaches and colds. ${ }^{267}$ In addition to the buadienolide $517,{ }^{268}$ two eudesmane sesquiterpenoids were isolated, $\mathbf{5 4 7}$ and 548. These were the first to be reported from the Hyacinthaceae and due to their occurrence in $U$. epigea but not the oft-confused $U$. altissima, provide species level taxonomic markers. ${ }^{267}$ The bufadienolide 517, has an unusual 3,5-diene system, readily obtained synthetically, but not commonly isolated directly from plant sources. ${ }^{268}$ The butanol extract of the bulbs of $U$. epigea was found to have significant molluscicidal activity against the bilharzia-carrying snail, Bulinus africanus. This result has raised some concern with regards its use as soap and the potential toxic affect it may have on other aquatic biota. ${ }^{269}$

An Indian member of the Urgineoideae, known locally as 'jungli-piyaz' or 'bhuikanda' and Indian squill has been used traditionally for stomach complaints, as a cardiac stimulant, a diuretic, as well as to treat asthma, cough or bronchitis and various infections. ${ }^{270}$ Commercially available samples vary with some plants having a truncated bulb and others a scaly bulb. ${ }^{271}$ For much of the work reported, the plant has been identified as Urginea indica (Roxb.) Kunth or Scilla indica Baker. The name Indurgia indica (Roxb.) Speta is currently accepted. Extracts of the bulbs have shown some activity against Neisseria gonorrhoeae infections ${ }^{272}$ and have had outstanding antimicrobial activity attributed to them in a survey of medicinally used plants in India. ${ }^{273}$ The ethanolic extract of the bulbs of I. indica (as Scilla indica Baker) has been found to have good antioxidant activity (protection against lipid peroxidation induced by ferrous sulphate in a dose-dependant manner, with $49 \%$ protection for hydroxyl radical-mediated hydroxylation at a concentration of $250 \mu \mathrm{g} \mathrm{ml} \mathrm{m}^{-1}$ ) as well as to possess cardiac activity on a par with ouabain. ${ }^{271,274}$ Rao and Rangaswami have detected bufadienolides in extracts of the bulbs of $I$. indica (as Scilla indica Roxb.) and have isolated scillaren A 224 as the principle active component. ${ }^{275,276}$ Jha and Sen, however, found no trace of scillaren A $\mathbf{2 2 4}$ in a plant identified as Scilla indica at the time. ${ }^{277}$ The principle bufadienolides isolated from this plant (as Urginia indica Kunth) by various investigators are scillaren A 224 and proscillaridin A 223, ${ }^{275,278-281}$ with scillaren A being reported as early as 1956 . These are also the principle bufadienolides of the European squill $C$. maritima. In small doses, the action of $I$. indica is the same as $C$. maritima, in that it slows the heart beat and increases urine flow and it can successfully be used as a substitute for C. maritima. ${ }^{\mathbf{2 8 2}}$ Jha and $\operatorname{Sen}^{\mathbf{2 7 8 , 2 8 0}}$ have studied the twelve different cytotypes of $I$. indica (as Urginea indica), belonging to four ploidy levels. Scillaren A $\mathbf{2 2 4}$ and proscillaridin A $\mathbf{2 2 3}$ were present in all twelve. Bulbs were investigated through three successive years. The tetraploids showed the highest concentration of these bufadienolides, followed by diploids and then triploids. Significant variation in the bufadienolide concentration was also noted between samples collected in northern and southern India, with the northern samples showing much lower levels of proscillaridin A 223 and scillaren A 224. ${ }^{283}$ In addition, two minor components, scilliphaeoside $\mathbf{4 3 6}$ and anhydroscilliphaeosidin, were found to be present in the tetraploid cytotypes and

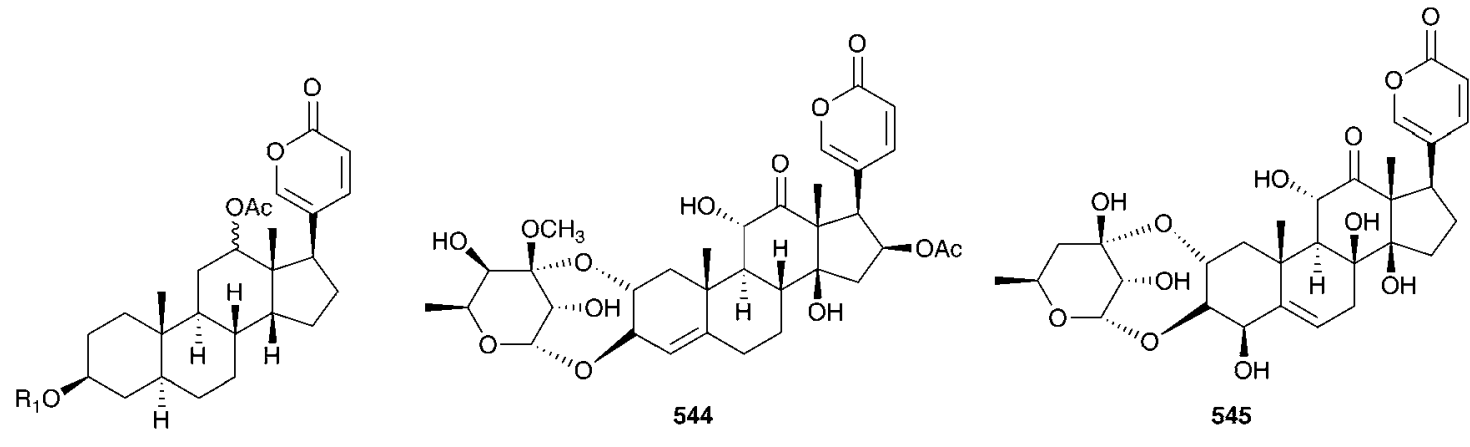

$540 R_{1}=\beta$-D-xylopyranosyl- $(1 \rightarrow 4)-\mathrm{O}-\alpha$-L-rhamnopyranoside

$541 \mathrm{R}_{1}=\beta$-D-glucopyranosyl-( $\left.1 \rightarrow 3\right)$-O-4-acetyl- $\alpha$-L-rhamnopyranoside 


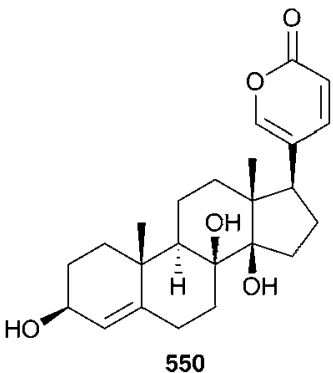

550<smiles>COc1c(O)cc2c(c1OC)C(=O)CC(c1ccc3c(c1)OCO3)O2</smiles>

551 R = 6"- $\beta$-D-glucopyranosyl- $\beta$-Dglucopyranoside

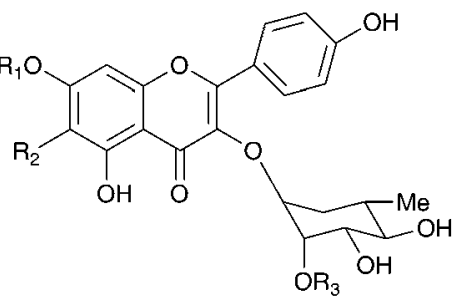

$552 \mathbf{R}_{1}=6$ - $p$-coumaroyl- $\beta$-D-glucopyranoside, $\mathrm{R}_{2}=\mathrm{C}$-glucopyranoside, $\mathrm{R}_{3}=\mathrm{H}$ $553 \mathbf{R}_{1}=6$ - $p$-coumaroyl $-\beta$-D-glucopyranoside, $R_{2}=-C$-glucopyranoside, $R_{3}=-\beta$-Dglucopyranosyl scilliphaeoside $\mathbf{4 3 6}$ in the triploids. Likewise the sterol content was investigated with only minor differences noted between the ploidy levels. Stigmasterol predominated, with sitosterol and campesterol being found in the tetraploid cytotypes and some of the triploids respectively. ${ }^{284,285} \mathrm{Kopp}$ and Danner ${ }^{281}$ found the bulbs of I. indica (as Urginia indica) to contain six bufadienolides, scillarenin 512, proscillaren A 223, scillarenin A 224, scilliphaeosidin $3-O-\alpha-\mathrm{L}-$ rhamnopyranoside 549 , scilliglaucosidin 3-O- $\alpha$-L-rhamnopyranoside 534 and scilliglaucosidin $3-O-\beta-$ D-glucopyranoside 535, while Saxena and Chaturvedi isolated 6desacetoxy scillirosidin $\mathbf{5 5 0} .{ }^{286}$ In addition to the bufadienolides and sterols, Sultana et al. have isolated three novel flavonoid glycosides (551-553) from bulbs collected in Bangladesh. ${ }^{287}$

Seasonal variation in the glycosidal content of the bulbs has been observed with the highest such levels found during October at the onset of dormancy. The levels steadily decrease to reach a minimum in June. ${ }^{288}$ Sterol content has been found to peak during the pre-flowering and pre-vegetative growth stages and it has been suggested that the sterols could be a trigger for the onset of reproductive and vegetative growth in the species. ${ }^{289}$ Significant antifungal activity has been noted and attributed to the presence of a 29-kDa glycoprotein which inhibited growth of Fusarium oxysporum at a concentration of 10 $\mu \mathrm{g}$ protein well ${ }^{-1} .{ }^{290,291}$ This protein has in addition shown good antitumour activity against the growth of an ascites tumour and mouse mammary carcinoma (tested in vivo using 6-8 week old female mice). ${ }^{292}$ The bulbs of I. indica (as Urginia indica L.) collected in Nigeria were found to contain six alkylresorcinols of the structure types shown in $\mathbf{5 5 4}$ and $\mathbf{5 5 5} .{ }^{293}$ An ethanolic extract of I. indica (as Scilla indica), has reportedly shown good

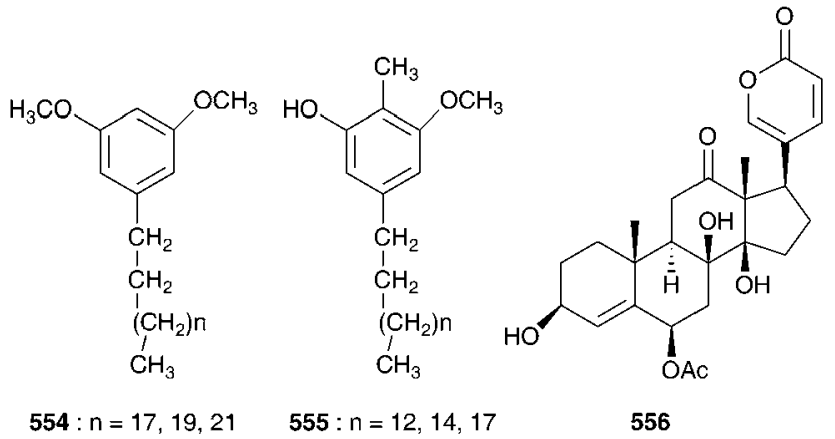

$554: n=17,19,21$

$555: n=12,14,17$

556 inhibition of the Semliki Forest Virus and the active principal found to be a diosgenin saponin..$^{294}$

The genus Drimia Jacq. is closely related to Urginea. Drimia robusta Baker is widely used in southern Africa by traditional healers. It has been used as a diuretic, as a treatment for feverish colds, to promote the healing of broken bones, to treat diseases of the uterus and to relieve stabbing pains in the chest. ${ }^{258,295}$ Luyt et al. ${ }^{295}$ investigated the biological activity of this plant in order to substantiate its use in traditional medicine. Anti-bacterial activity was found to be present in the ethyl acetate extract of the bulbs. An ethanolic extract of the bulbs showed higher inhibitory activity than indomethacin in the screening for inhibition of cyclooxygenase. This inhibition of prostaglandin synthesis (tested for with the cyclooxygenase assay) could explain the plant's use as a treatment for feverish colds. Further work on the COX-1 inhibition of a water extract of the bulbs showed activity above $70 \% .{ }^{264}$ Evidence for the presence of proscillaridin A 223 was presented: TLC and NMR data were compared with a standard sample. Luyt et al. ${ }^{296}$ then compared bulbs derived from tissue culture with those grown naturally. A standard proscillaridin A 223 was used for comparison and the UV spectra and qualitative TLC results were compared. The results indicated that the bufadienolide content was the same in the in vitro-derived plants as in those grown naturally. This is in contrast to the work done on C. maritima, where no bufadienolides were found in the tissue cultured bulbs. ${ }^{230}$ Phytochemical studies of the bulbs of $D$. robusta yielded eight bufadienolides, 12ß-hydroxyscillirosidin 445, $6 \beta$-acetoxy-3 $\beta, 8 \beta, 14 \beta$-trihydroxy-12-oxobufa- $4,20,22$ trienolide 556, scilliroside 430, 12 $\beta$-hydroxyscilliroside 446, hellebrigenin-3-O- $\beta$-glucopyranoside $531, \quad 16 \beta$-hydroxyhellebrigenin 557, 16 $\beta$-hydroxyhellebrigenin-3-O- $\beta$-glucopyranoside 558 and $5 \beta, 16 \beta$-dihydroxybufalin-3-O- $\beta$-glucopyranoside 559 as well as three common aromatic acids, 4-hydroxy-3-methoxybenzoic acid, 3,4-dihydroxybenzoic acid and trans-3-(4'hydroxyphenyl)-2-propenoic acid. ${ }^{258,268,297}$ The toxicity of Rhodocodon madagascariensis Baker, a plant endemic to Madagascar, has been tested against the embryo-larvae of medaka fish (Oryzias latipes) and an $\mathrm{LD}_{50}$ of $1 \mathrm{mg} \mathrm{ml}^{-1}$ was established. ${ }^{298}$

Work on the genus Bowiea Harv. ex Hook.f. has centred on Bowiea volubilis Harv. ex Hook.f. Most of the investigations were carried out in the 1950s and early 1960s. This African species is 
toxic and as early as 1938, the presence of a cardioactive glucoside was reported. ${ }^{299}$ Katz and Tschesche et al. have between them reported the presence of several bufadienolides (bovisides A 560, B, C, D, bovogenin E, bowieasubstanz G, glucobovoside A 561, nabogenin (scilliglaucosidin) 532, bovoruboside 562 and bovogenin A 563) between the years of 1950 and $1959 .^{300-314}$ Structures have been reported for nabogenin 532, bovoruboside 562, bovoside A 560, glucobovoside A 561 and bovogenin A 563, although the structure reported for bovoruboside is not certain. The cardioactive glycosides from $B$. volubilis attracted much attention in the early years of their discovery. The activity was initially found to be in the region of strophanthin, ${ }^{315}$ the action was as rapid and lasting with a cumulative effect, though not as much as digitoxin..$^{316-318}$ Solutions of bovoside A were found to be unstable, due to the aldehyde group at C-19 being vulnerable to oxidation. Reduction of this group to the alcohol (bovosidol A) gave a stable solution which could then be assessed for activity. ${ }^{\mathbf{3 1 9 , 3 2 0}}$ Material from East Africa (as Bowiea kilimandscharica Mildbr.) was initially reported to contain two bufadienolides, kilimanscharogenins A and B. Katz concluded that kilimanscharogenin A was the same compound as bovogenin A 563. ${ }^{321}$

Chen and Henderson ${ }^{322,323}$ carried out a comparative survey of the cardioactivity of twenty-nine bufadienolides and cardenolides from various sources. Included in the survey were bufadienolides from $B$. volubilis. The tests were carried out on etherised cats by slow continuous intravenous injection and the electrocardiograms were recorded to confirm the digitalis-like action of these compounds. The potency of each compound was determined in terms of lethal dose (LD), the amount $\left(\mathrm{mg} \mathrm{kg}^{-1}\right)$ needed to kill a cat of approximately $2 \mathrm{~kg}$ in 30-60 min. The bufadienolides were found to be more potent than the cardenolides, with the glycosides seldom showing more activity than the aglycones. The methyl C-10 analogues were less active than the compounds with an aldehyde group in the $\mathrm{C}-10$ position and 3-epimerisation and $5 \alpha$-configuration reduced the activity. A later study by Chen increased the number of cardenolides and bufadienolides to fifty and similar profiles were obtained using the same assay system..$^{\mathbf{2 2 4}}$

\section{The Ornithogaloideae}

The Ornithogaloideae are widespread throughout Africa, Europe and southwest Asia. This group consists of approximately 280 species, ${ }^{5}$ with a recent phylogenetic analysis by
Martínez-Azorín et $a .^{6}{ }^{6}$ recognising nineteen monophyletic genera. Phytochemical studies on the Ornithogaloideae have centred on Ornithogalum L. and Galtonia Decne., primarily driven by the significant biological activity attributed to the compounds isolated. In addition, a small amount of work has been done on Albuca L., Eliokarmos Raf., Stellarioides Medik., Loncomelos Raf. and Honorius Gray. The types of compounds isolated are strongly linked to the geographic region the plant species derive from, with the African taxa containing primarily cholestane glycosides and spirosterols, and the European taxa cardenolides. Some flavonoids and sterols have been isolated from plants sourced from all regions studied. Additionally, a limited number of homoisoflavanones have been identified from the bulbs.

The genus Albuca L. is widespread in southern Africa, with some species occurring in the Arabian Peninsula. The bulbs of Albuca fastigiata Dryand. have been investigated and only one compound was isolated, a homoisoflavonoid, 564. ${ }^{325}$ Albuca fastigiata is found on the East coast of South Africa and is used by the Zulu as a protective charm and to treat malicious food poisoning. ${ }^{325}$ Another southern African species, Albuca setosa Jacq., has been tested for anti-inflammatory activity in a carrageenan-induced rat paw edema assay. ${ }^{326}$ This plant is used by traditional healers to treat wounds, among other conditions, and was found to significantly inhibit carrageenan-induced paw edema for a 3-hour challenge (43-55\% over $3 \mathrm{~h}$ at $150 \mathrm{mg} \mathrm{kg}$ and $68-85 \%$ for $300 \mathrm{mg} \mathrm{kg}^{-1}$ ). Albuca setosa has also been used by traditional healers in the Nkonkobe municipality in South Africa for the treatment of diabetes. ${ }^{327}$ As part of a study on the steroidal saponins of various monocot families, Okanishi et al. ${ }^{328}$ found Albuca nelsonii N.E.Br. to contain ruscogenin 565. This was identified by comparison of melting points, mixed melting points, optical rotations, infrared and mass spectra with an authentic sample.

Galtonia candicans (Baker) Decne. is native to South Africa, and was investigated by the laboratories of Kuroda and Mim$\mathrm{aki}^{329-333}$ who used bioassay-directed fractionation to isolate the active components of the bulbs. The methanol extract was found to be active against leukemia HL-60 cells $\left(\mathrm{IC}_{50}=0.017 \mu \mathrm{M}\right)$. This was further partitioned between n-butanol and water, with the activity being retained in the $n$-butanol fraction $\left(\mathrm{IC}_{50}=0.0056\right.$ $\mu \mathrm{M})$. This was found to contain the hexacyclic rearranged cholestane diglycoside, candicanoside A 566, the polyoxygenated $5 \beta$ cholestane diglycoside galtonioside A 567, six cholestane

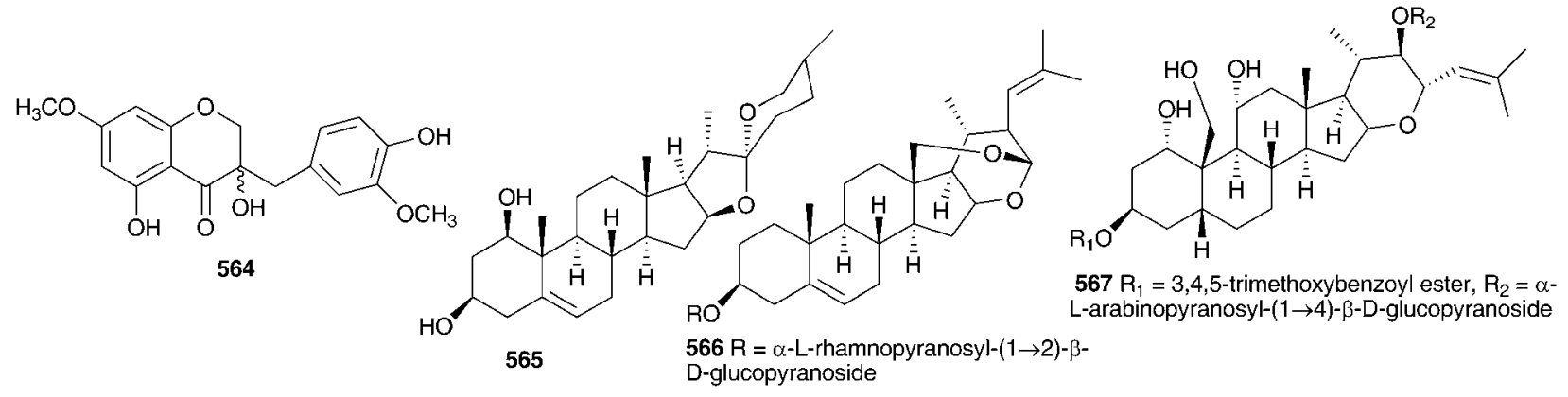




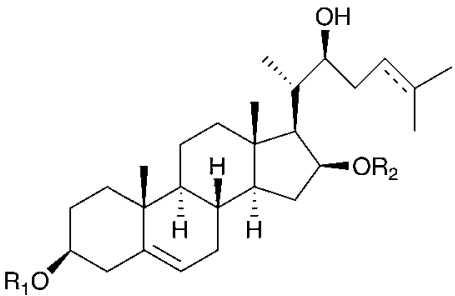

$568 R_{1}=\beta$-D-glucopyranoside, $R_{2}=3-O-$ acetyl- $\alpha$ - Lrhamnopyranoside $569 R_{1}=\beta$-D-glucopyranoside, $R_{2}=3-O-$ acetyl $-\alpha-L-$ rhamnopyranoside, $\Delta^{24}$

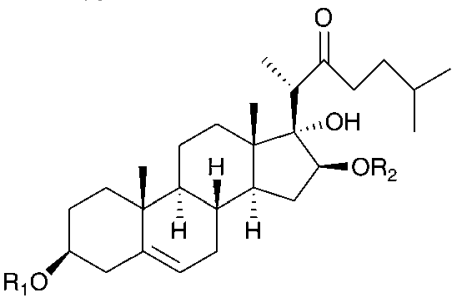

$575 R_{1}=\beta$-D-glucopyranoside, $R_{2}=(2-O-(E)-$ cinnamoyl- $\beta-D$-xylopyranosyl) $-(1 \rightarrow 3)-2$-O-acetyl- $\alpha$-Larabinopyranoside

$576 R_{1}=\beta$-D-glucopyranoside, $R_{2}=(2-O-3,4-$

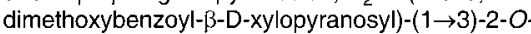
acetyl- $\alpha$-L-arabinopyranoside

$577 \mathrm{R}_{1}=\beta$-D-glucopyranoside,, $\mathrm{R}_{2}=\beta$-Dxylopyranosyl)- $(1 \rightarrow 3)-2-O$-acetyl- $\alpha-L$ arabinopyranoide

$578 R_{1}=\beta$-D-glucopyranoside, $R_{2}=\alpha-L-$ arabinopyranoside

$580 R_{1}=H, R_{2}=\alpha$-L-arabinopyranoside

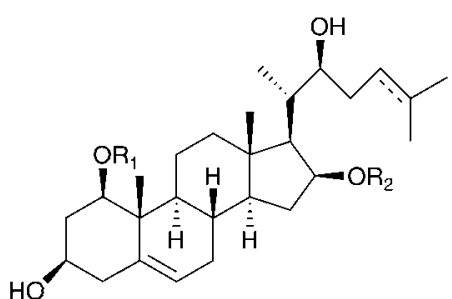

$570 R_{1}=\beta$-D-glucopyranoside, $R_{2}=\beta$-D-glucopyranoside

$571 \mathrm{R}_{1}=\beta$-D-glucopyranosyl- $(1 \rightarrow 6)-\beta-\mathrm{D}-$

glucopyranoside, $R_{2}=\beta$-D-glucopyranoside, $\Delta^{24}$

$572 \mathrm{R}_{1}=\beta$-D-glucopyranosyl- $(1 \rightarrow 6)$ - $\beta$-D-glucopyranoside,

$R_{2}=\beta$-D-glucopyranoside

$573 R_{1}=\alpha$-L-rhamnopyranoside, $R_{2}=\beta-D$ -

glucopyranoside

$574 R_{1}=\beta$-D-glucopyranoside, $R_{2}=\beta$-D-glucopyranoside

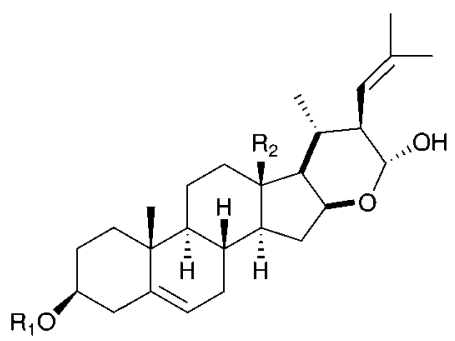

$579: R_{1}=\alpha$-L-rhamnopyranosyl- $(1 \rightarrow 2)-\beta-D$-glucopyranoside, $\mathrm{R}_{2}=\mathrm{CH}_{2} \mathrm{OH}$ bisdesmosides 568-573 and six cholestane glycosides 574579. ${ }^{329-333}$ Candicanoside A 566 and galtonioside A 567 were found to have potent activity against leukemia HL-60 cells $\left(\mathrm{IC}_{50}=\right.$ $0.032 \mu \mathrm{M}$ and $0.057 \mu \mathrm{M}$ respectively) and further testing on a 38 cell line assay showed differential cytotoxicities against breast cancer, CNS cancer and lung cancer lines, while colon cancer, ovarian cancer and stomach cancer cell lines were resistant to them. ${ }^{330,331}$ Compound 569 showed moderate activity against leukemia HL-60 cell lines $\left(\left(\mathrm{IC}_{50}=6.8 \mu \mathrm{M}\right)^{332}\right.$ and compounds 575-578 showed good activity using the same assay $\left(\mathrm{IC}_{50}=\right.$ $0.00012 \mu \mathrm{M}, 0.00048 \mu \mathrm{M}, 0.0024 \mu \mathrm{M}$ and $0.053 \mu \mathrm{M}$ respectively). ${ }^{333}$ Tang and Yu have achieved the total synthesis of candicanoside A 566, using a 27-step synthesis. ${ }^{334,335}$ Another southern African species of Galtonia that has received some attention is Galtonia princeps (Baker) Decne. ${ }^{336}$ A methanol extract of the bulbs yielded the cholestane derivative 580 . Both the bulbs and aerial leaves of Galtonia viridiflora I.Verd. were found to contain monoglycosides of caffeic acid, principally rhamnose and glucose. ${ }^{337}$

Work on the bulbs of Galtonia saundersiae (Baker) Mart.Azorín, M.B.Crespo \& Juan (as Ornithogalum saundersiae), a native of the East coast of South Africa, began in the early 1990s with the isolation of three acylated cholestane glycosides 581583. All three were examined for their inhibitory effect on cyclic AMP phosphodiesterase. Compounds 582 and 583 showed good activity $\left(\mathrm{IC}_{50}=0.00025 \mu \mathrm{M}\right.$ and $0.00020 \mu \mathrm{M}$ respectively), suggesting that the presence of a benzoyl group attached to the sugar moiety is essential for activity. ${ }^{338}$ Six additional cholestane glycosides 584-589 were isolated and tested for their inhibitory activity on cyclic AMP phosphodiesterase. Compounds 585 and $\mathbf{5 8 8}$, with the acyl group at the C-3 hydroxyl position of the rhamnose group, showed good activity $\left(\mathrm{IC}_{50}=9.9 \times 10^{-5} \mu \mathrm{M}\right.$ and $10.9 \times 10^{-5} \mu \mathrm{M}$ respectively), as did compound $589(40 \%$ inhibition at $0.08 \mathrm{mg} \mathrm{ml}^{-1}$ ), while the other compounds were inactive. ${ }^{339,340}$ Compound 590, isolated from the bulbs of $G$. saundersiae (as Ornithogalum saundersiae), showed significant inhibition $\left(\mathrm{IC}_{50}=3.1 \mu \mathrm{M}\right)$ of the proliferation of peripheral blood lymphocytes produced by a patient with chronic renal failure, suggesting potential as an immunosuppressive agent. Rearranged cholestane glycosides (591-599) with a sixmembered hemiacetal ring $\mathrm{E}$, between $\mathrm{C}-16$ and C-23, have been isolated. The conformation of ring $\mathrm{E}$ was determined through molecular mechanics and molecular dynamics calculations. ${ }^{341}$ These compounds were tested for anti-tumour activity, primarily against leukaemia HL-60 cells and MOLT-4 cells. Compounds $591\left(\mathrm{IC}_{50}=21.0 \mathrm{nM}\right.$ and $\left.18.0 \mathrm{nM}\right), 592\left(\mathrm{IC}_{50}=9.2\right.$ $\mathrm{nM}$ and $3.2 \mathrm{nM}$ ) and 597-599 $\left(\mathrm{IC}_{50}=0.019,0.063\right.$ and $0.052 \mu \mathrm{M}$ for HL-60 cells) showed significant cytotoxic activity, primarily through the induction of apoptosis. These results would indicate that the presence of an aromatic ester group at the glycoside moiety is essential for good activity. ${ }^{342-348}$ Further investigation of the methanol extract of the bulbs resulted in the isolated of the related cholestane glycoside $600 .{ }^{349}$ In addition to the rearranged cholestane glycosides mentioned above, ten new (575, 601-609) and three previously isolated (567-569) cholestane glycosides, with a glycosidic moiety at C-16 have been 


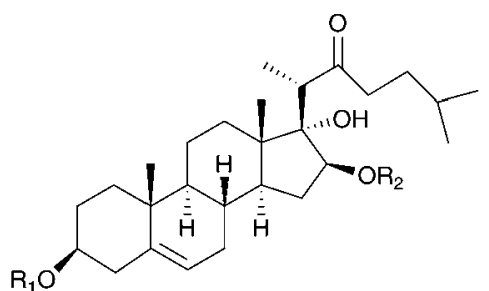

$581 \mathbf{R}_{1}=\mathrm{H}, \mathbf{R}_{2}=\beta$-D-xylopyranosyl-2-O-acetyl$(1 \rightarrow 3)-\alpha-L$-arabinopyranoside

$582 R_{1}=H, R_{2}=2-O-4$-methoxybenzoyl- $\beta$-Dxylopyranosyl-2-O-acetyl-(1 $\rightarrow 3)-\alpha-\mathrm{L}-$

arabinopyranoside

$583 \mathrm{R}_{1}=\mathrm{H}, \mathrm{R}_{2}=2-0-3,4$-dimethoxybenzoyl- $\beta$ D-xylopyranosyl-2-O-acetyl- $(1 \rightarrow 3)-\alpha-L$ -

arabinopyranoside

$602 \mathrm{R}_{1}=\mathrm{H}, \mathrm{R}_{2}=2-\mathrm{O}-(E)$-cinnamoyl- $\beta$-D-

xylopyranosyl-2-O-acetyl-(1 $\rightarrow 3)-\alpha-L-$

arabinopyranoside

$603 R_{1}=\beta$-D-glucopyranoside, $R_{2}=2-O-4$

methoxybenzoyl- $\beta$-D-xylopyranosyl-2-O-acetyl-

$(1 \rightarrow 3)-\alpha-L-a r a b i n o p y r a n o s i d e$

$608 \mathrm{R}_{1}=\mathrm{H}, \mathrm{R}_{2}=\beta$-D-glucopyranosyl-2-O-3,4-

dimethoxybenzoyl- $\beta$-D-xylopyranosyl-2-O-

acetyl- $(1 \rightarrow 3)-\alpha$-L-arabinopyranoside

$609 \mathrm{R}_{1}=\mathrm{H}_{1} \mathrm{R}_{2}=\beta$-D-glucopyranosyl-2-O-

3,4,5-trimethoxybenzoyl- $\beta$-D-xylopyranosyl-2-

$O$-acetyl- $(1 \rightarrow 3)-\alpha-L$-arabinopyranoside

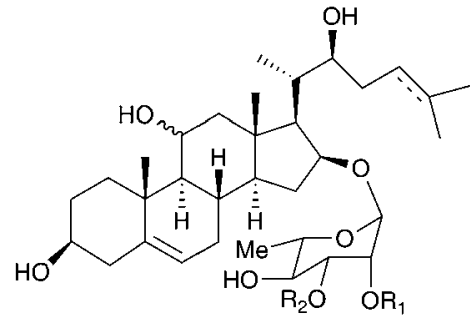

$584 \mathrm{R}_{1}=\mathrm{H}, \mathrm{R}_{2}=\mathrm{H}, \mathrm{C}-11 \alpha$

$585 R_{1}=H, R_{2}=A C, C-11 \beta$

$586 \mathrm{~A}_{1}=\mathrm{AC}, \mathrm{R}_{2}=\mathrm{H}, \mathrm{C}-11 \beta$

$587 \mathrm{R}_{1}=\mathrm{H}, \mathrm{R}_{2}=\mathrm{H}, \mathrm{C}-11 \alpha, \Delta^{24}$

$588 R_{1}=H, R_{2}=A C, C-11 \beta, \Delta^{24}$

$604 R_{1}=A c, R_{2}=A c, C-11 \alpha$

$605 \mathrm{R}_{1}=\mathrm{Ac}, \mathrm{R}_{2}=3,4,5$-trimethoxybenzoyl, $\mathrm{C}-11 \mathrm{c}$

$606 R_{1}=A c, R_{2}=p$-methoxybenzoyl, C- $11 \alpha$

$607 R_{1}=A C, R_{2}=A C, C-11 \alpha, \Delta^{24}$

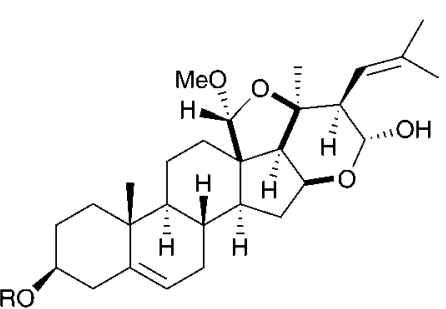

$589 \mathrm{R}=\alpha$-L-rhamnopyranosyl-( $(1 \rightarrow 2)-\beta$-D-glucopyranosyl- $(1 \rightarrow 2)-\beta$ D-glucopyranoside

$592 \mathrm{R}=4$-O-4-methoxybenzoyl- $\alpha$-L-rhamnopyranosyl- $(1 \rightarrow 2)-\beta-\mathrm{D}$ glucopyranoside

$593 \mathrm{R}=\alpha$-L-rhamnopyranosyl-(1 $\rightarrow 2)-\beta$-D-glucopyranoside

$594 \mathrm{R}=4-O-4-m e t h o x y b e n z o y l-\alpha-L-$-rhamnopyranosyl-( $1 \rightarrow 2)-\beta$-D-

glucopyranoside tested for their inhibitory activity against leukemia HL-60 cells and MOLT-4 cells. All these compounds showed significant activity, with a loss of activity noted each time the ester group on the sugar moiety was removed. ${ }^{350-353}$ Due to the significant anti- tumour activity shown by these plant extracts, a number of patents have been filed in Japan and China covering the extract methods used, the use of the saponins and, in some cases, the synthesis of the active components. ${ }^{354-358}$ In particular, 567

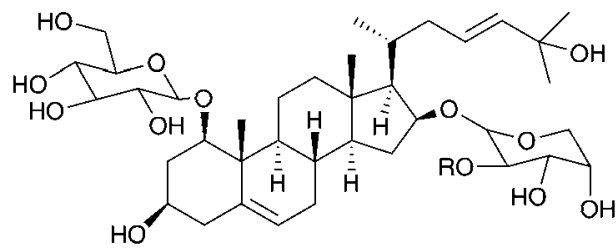

$601 \mathrm{R}=3,4,5$-trimethoxybenzoyl

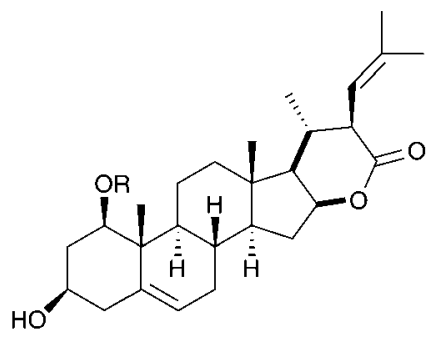

$600 \mathrm{R}=\beta$-D-glucopyranosyl- $(1 \rightarrow 6)-\beta-\mathrm{D}$-glucopyranoside

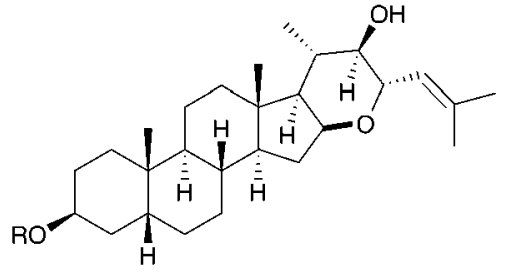

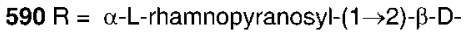
glucopyranosyl-( $(1 \rightarrow 2)-\beta-D$-glucopyranoside

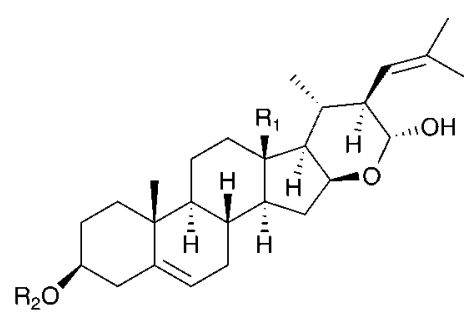

$591 \mathrm{R}_{1}=\mathrm{CHO}, \mathrm{R}_{2}=4-O-4$-hydroxybenzoyl- $\alpha-L-$ rhamnopyranosyl- $(1 \rightarrow 2)-\beta-\mathrm{D}-$ glucopyranoside $595 \mathrm{R}_{1}=\mathrm{CHO}, \mathrm{R}_{2}=\alpha$-L-rhamnopyranosyl-(1 $\left.\rightarrow 2\right)$ - $\beta$-D-glucopyranosyl- $(1 \rightarrow 2)-\beta$-Dglucopyranoside

$596 \mathrm{R}_{1}=\mathrm{CHO}, \mathrm{R}_{2}=\alpha$-L-rhamnopyranosyl-(1 $\left.\rightarrow 2\right)-\beta-\mathrm{D}$-glucopyranoside $597 \mathrm{R}_{1}=\mathrm{CHO}, \mathrm{R}_{2}=4-O-4$-methoxybenzoyl- $\alpha$ - L-rhamnopyranosyl- $(1 \rightarrow 2)-\beta-\mathrm{D}$ glucopyranoside

$598 \mathrm{R}_{1}=\mathrm{CH}_{2} \mathrm{OH}, \mathrm{R}_{2}=4-0$-4-hydroxybenzoyl- $\alpha$-L-rhamnopyranosyl- $(1 \rightarrow 2)-\beta-\mathrm{D}$ glucopyranoside

$599 \mathrm{R}_{1}=\mathrm{CH}_{2} \mathrm{OH}, \mathrm{R}_{2}=4-0-4-$ methoxybenzoyl- $\alpha$-L-rhamnopyranosyl- $(1 \rightarrow 2)-\beta-\mathrm{D}-$ glucopyranoside 
(called OSW1) has been the subject of much synthetic work. The full synthesis of the compound itself has been accomplished, and a large number of analogues have been produced for structure-activity relationship studies. Studies indicate that OSW1 acts by damaging the mitochondria and inducing apoptosis through an increase of cytosolic calcium and thus the activation of calcium dependent apoptosis. It has been demonstrated that OSW1 is active against some cells that are resistant to conventional anti-cancer agents, in particular fludarabine-resistant chronic lymphocytic leukemia cells. ${ }^{359}$ In addition to the work on the anti-tumour activity of G. saundersiae, the ethanol extract of the whole dried plant has been tested for its protective effects against acute hepatic failure. The authors concluded that it did provide some benefit, primarily through suppressing oxidative stress, lipid peroxidation and apoptosis of hepatocytes, as well as reducing inflammation..$^{360,361}$

Species from the genus Ornithogalum have received substantial attention. While early work on the genus began in the 1950s on the European members of the genus, later work has included species from Turkey and Iran.

Work on the European species of Ornithogalum was initially centred on Ornithogalum umbellatum L. (common Star of Bethlehem). European species of Ornithogalum are characterised by the presence of cardenolides, with some flavonoids also identified. Extracts of the bulbs of $O$. umbellatum were found to have a digitalis-like effect on frog, rabbit and cat hearts. In all cases, a positive inotropic action was noted, decreased conduction and finally systolic standstill. ${ }^{362-364} \mathrm{~A}$ clinical trial found that when tablets of O. umbellatum were substituted for digitoxin there was a loss of activity and fluid retention increased. When the tablets were coated to protect them from stomach acid, the digitalis-like action was re-established but at only half the expected strength. It was concluded that only half the active components were being absorbed. When compared to digitoxin, the drug showed less slowing of the heart, a greater diuretic effect and less gastrointestinal nausea. ${ }^{365}$ The principal active component of $O$. umbellatum was found to be the cardenolide convallatoxin $610 .{ }^{366}$ The cytotoxicity of convallatoxin $\mathbf{6 1 0}$ was studied. It was found to have an $\mathrm{IC}_{50}$ of $002 \mu \mathrm{g} \mathrm{m}{ }^{-1}$ when assayed against Eagle's KB strain of human carcinoma and structure-activity studies showed that the glycosidic portion was essential for activity and that the $\beta$-hydroxy groups at C-5 and C-14 and the aldehyde at C-10 significantly enhanced the activity. ${ }^{367}$ The convallatoxin $\mathbf{6 1 0}$ content in the bulbs can be increased by defloration of the plant. ${ }^{368}$ In total, sixteen cardenolides (610-626) have been isolated from the bulbs of O. umbellatum $\mathrm{L}^{366,369-371}$ Later phytochemical investigations of the bulbs resulted in the isolation and identification of two flavonoids (627 and 628) ${ }^{372}$ while the four flavonoids (627-630) were isolated from the leaves. ${ }^{372,373}$ Compounds $\mathbf{6 2 9}$ and $\mathbf{6 3 0}$ were also isolated from the leaves of Ornithogalum algeriense Boiss. and Ornithogalum kochii Parl. ${ }^{373}$ Sabudak and Oyman reported the presence of 3-O-(2'-methoxy-4'-(2-pentenal))-phenylsitosterol in the bulbs of O. umbellatum ${ }^{374}$ and a study of the roots colonized by the fungus Glomus intraradices found a complex range of apocarotenoids. ${ }^{375} \mathrm{~A}$ range of cardenolides have been isolated from the species Loncomelos magnum (Krasch. \& Schischk.) Speta (as Ornithogalum magnum) $(610,614,631-635),{ }^{376-382}$ Honorius nutans (L.) Gray (as Ornithogalum nutans) $(610,631,632$, 636-664), ${ }^{383,384}$ Ornithogalum gussonei Ten. $(631,635,665)^{385}$ and Honorius boucheanum (Kunth) Holub (as Ornithogalum boucheanum) (666-673). ${ }^{386}$ The aerial parts of O. gussonei yielded two flavonoids saponaretin 674 and saponarin $675 .{ }^{387}$ A terpene glucoside (676) has been isolated from Ornithogalum montanum $\mathrm{Cyr}^{388}$ and the main water soluble polysaccharide of the bulbs of Ornithogalum ponticum (Zahar.) Speta was found to be a neutral glucofructan with a glucose : fructose ratio of $30: 1 .{ }^{57,389}$

A comparative study on the Bulgarian species Ornithogalum nanum Sibth. \& Sm., O. gussonei, Loncomelos narbonense (L.) Raf. (as $O$. narbonense), and O. montanum Cyr. resulted in cardenolides (677-681) being found in the bulbs of $O$. nanum and $O$. gussonei but not in the bulbs of the other two species. ${ }^{390}$

The leaves and bulbs of the Turkish species Ornithogalum alpigenum Stapf. have been tested for antioxidant activity, antimicrobial activity and as free radical scavengers. The leaf extracts were found to be good free radical scavengers $(90.9 \%)$ and the bulb extracts (methanol, ethanol, acetone and benzene) showed variable activity against Candida albicans, Bacillus subtilis and Bacillus cereus. The highest antioxidant activity was found in the methanol extract of the bulbs $(88.1 \%$ on a $\beta$-carotene-linoleic acid system) and the lowest in the benzene extract of the bulbs. ${ }^{391}$ The Iranian species Ornithogalum procerum Stapf. and Ornithogalum cuspidatum Bertol. have received some attention. The aerial parts of $O$. cuspidatum are used in Iran as food additives as well as an anti-irritant and relaxant to soothe the throat when suffering from a dry cough. The essential oils in the leaves, flowers and bulbs have been determined by GC-MS. The flowers and bulbs contained primarily saturated hydrocarbons, while the leaves contained oxygenated hydrocarbons and terpenoid compounds. ${ }^{392}$ In addition, a GS-MS analysis of the methanol extract of the bulbs has allowed for the identification of thirteen phytosterols (cholesterol, 3,5-didehydrostigmastan-6,22-diene, 4,4-dimethyl-5 $\alpha$-cholest-7-en3 -one, $4 \beta$-methylcholesterol, 5-cholestene-3 $\beta, 7 \beta$-diol, campesterol, cholest-4-ene-3,6-dione, stigmast-4-en-3-one, stigmasta-3,5-dien-7one, stigmasterol, $\Delta^{5}$-ergostenol, $\beta$-sitosterol and $\gamma$-sitosterol). ${ }^{393} \mathrm{~A}$ GC-MS analysis of the aerial parts and bulbs of $O$. procerum resulted in the identification of twenty-three essential oils in the aerial parts and four polysterol-type compounds in the bulbs. ${ }^{394}$ Ornithogalum sintensii Freyn, another Iranian species, has been tested for antioxidant activity. A higher phenolic and flavonoid content in the aerial parts of the plant relative to the bulbs, accounted for the greater antioxidant activity in those extracts $\left(\mathrm{IC}_{50}\right.$ for DPPH radical scavenging activity of 368 and $669 \mu \mathrm{g} \mathrm{ml} \mathrm{m}^{-1}$ for leaves and bulbs respectively). ${ }^{395}$

Eliokarmos thyrsoides (Jacq.) Raf. is found in southwestern South Africa. Although not reportedly used by traditional healers it has been strongly linked to stock poisoning. ${ }^{1}$ Accordingly, the bulbs have been the subject of many phytochemical investigations. An initial investigation of the methanol extract of the bulbs in 1992 (as Ornithogalum thyrsoides) resulted in the isolation of four cholestane bisdesmosides (682685), with 685 showing some inhibitory activity on cyclic AMP phosphodiesterase $\left(\mathrm{IC}_{50}=15.3 \times 10^{-5} \mathrm{M}\right){ }^{396}$ Following the discovery that the methanol extract of the bulbs showed potent 


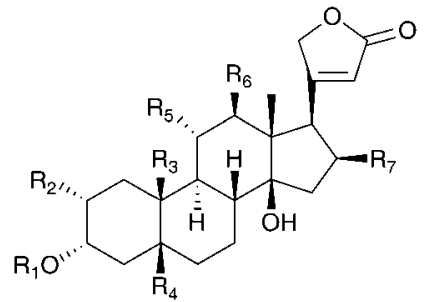

$610 \mathrm{R}_{1}=\alpha$-L-rhamnopyranoside, $\mathrm{R}_{2}=\mathrm{H}, \mathrm{R}_{3}=\mathrm{CHO}, \mathrm{R}_{4}=\mathrm{OH}, \mathrm{R}_{5}=\mathrm{H}, \mathrm{R}_{6}=\mathrm{H}, \mathrm{R}_{7}=\mathrm{H}$

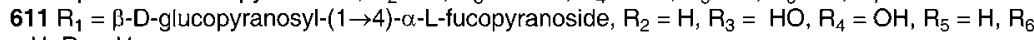
$=\mathrm{H}, \mathrm{R}_{7}=\mathrm{H}$

$612 \mathrm{R}_{1}=\alpha$-L-rhamnopyranoside, $\mathrm{R}_{2}=\mathrm{H}, \mathrm{R}_{3}=\mathrm{CH}_{2} \mathrm{OH}, \mathrm{R}_{4}=\mathrm{OH}, \mathrm{R}_{5}=\mathrm{H}, \mathrm{R}_{6}=\mathrm{H}, \mathrm{R}_{7}=\mathrm{H}$

$613 R_{1}=6$-deoxy- $\beta$-D-gulopyranoside, $R_{2}=H, R_{3}=C H O, R_{4}=O H, R_{5}=H, R_{6}=H, R_{7}=H$

$614 R_{1}=\alpha$-L-rhamnopyranoside, $R_{2}=H, R_{3}=C_{3}, R_{4}=H, R_{5}=O H, R_{6}=H, R_{7}=H$

$615 \mathrm{R}_{1}=\alpha$-L-rhamnopyranosyl- $\beta$-D-glucopyranoside, $\mathrm{R}_{2}=\mathrm{H}, \mathrm{R}_{3}=\mathrm{CH}_{3}, \mathrm{R}_{4}=\mathrm{H}_{1} \mathrm{R}_{5}=\mathrm{OH}, \mathrm{R}_{6}=$

$\mathrm{H}, \mathrm{R}_{7}=\mathrm{H}$

$616 \mathrm{R}_{1}=6$-desoxy- $\beta$-D-allopyranoside, $\mathrm{R}_{2}=\mathrm{H}, \mathrm{R}_{3}=\mathrm{CHO}, \mathrm{R}_{4}=\mathrm{OH}, \mathrm{R}_{5}=\mathrm{H}, \mathrm{R}_{6}=\mathrm{H}, \mathrm{R}_{7}=\mathrm{H}$

$617 \mathrm{R}_{1}=\beta$-D-allopyranoside, $\mathrm{R}_{2}=\mathrm{H}, \mathrm{R}_{3}=\mathrm{CHO}, \mathrm{R}_{4}=\mathrm{OH}, \mathrm{R}_{5}=\mathrm{H}, \mathrm{R}_{6}=\mathrm{H}, \mathrm{R}_{7}=\mathrm{H}$

$618 R_{1}=3$-acetyl- $\beta$-digitopyranosyl- $\beta$-D-glucopyranosyl- $\alpha$-L-rhamnopyranoside, $R_{2}=H, R_{3}=$

$\mathrm{CHO}, \mathrm{R}_{4}=\mathrm{OH}, \mathrm{R}_{5}=\mathrm{H}, \mathrm{R}_{6}=\mathrm{H}, \mathrm{R}_{7}=\mathrm{H}$

$619 \mathrm{R}_{1}=\alpha$-L-rhamnopyranoside, $\mathrm{R}_{2}=\mathrm{H}, \mathrm{R}_{3}=\mathrm{CHO}, \mathrm{R}_{4}=\mathrm{OH}, \mathrm{R}_{5}=\mathrm{OH}, \mathrm{R}_{6}=\mathrm{H}, \mathrm{R}_{7}=\mathrm{H}$

$620 R_{1}=6$-desoxy- $\beta$-D-allopyranoside, $R_{2}=H, R_{3}=C_{3}, R_{4}=O H, R_{5}=H, R_{6}=H, R_{7}=H$

$621 R_{1}=6$-desoxy- $\beta$-D-gulopyranoside, $R_{2}=H, R_{3}=C_{3}, R_{4}=H, R_{5}=O H, R_{6}=H, R_{7}=H$

$622 R_{1}=6$-desoxy- $\beta$-D-allopyranoside, $R_{2}=H, R_{3}=C_{3}, R_{4}=H, R_{5}=O H, R_{6}=H, R_{7}=H$

$623 R_{1}=\beta$-D-allopyranoside, $R_{2}=H, R_{3}=C_{3}, R_{4}=H, R_{5}=O H, R_{6}=H, R_{7}=H$

$624 R_{1}=6$-desoxy- $\alpha$-L-glucopyranose, $R_{2}=H, R_{3}=C_{3}, R_{4}=O H, R_{5}=O H, R_{6}=H, R_{7}=H$

$625 \mathrm{R}_{1}=\alpha$-L-rhamnopyranoside, $\mathrm{R}_{2}=\mathrm{H}, \mathrm{R}_{3}=\mathrm{CH}_{3}, \mathrm{R}_{4}=\mathrm{OH}, \mathrm{R}_{5}=\mathrm{OH}, \mathrm{R}_{6}=\mathrm{H}, \mathrm{R}_{7}=\mathrm{H}$

$626 \mathrm{R}_{1}=\beta$-D-ribose, $\mathrm{R}_{2}=\mathrm{H}, \mathrm{R}_{3}=\mathrm{CH}_{3}, \mathrm{R}_{4}=\mathrm{OH}, \mathrm{R}_{5}=\mathrm{OH}, \mathrm{R}_{6}=\mathrm{H}, \mathrm{R}_{7}=\mathrm{H}$

$631 R_{1}=\alpha$-L-rhamnopyranoside, $R_{2}=H, R_{3}=C_{3}, R_{4}=H, R_{5}=O H, R_{6}=H, R_{7}=H$

$632 \mathrm{R}_{1}=\alpha$-L-rhamnopyranosyl- $\beta$-D-glucopyranoside, $\mathrm{R}_{2}=\mathrm{H}, \mathrm{R}_{3}=\mathrm{CH}_{3}, \mathrm{R}_{4}=\mathrm{H}, \mathrm{R}_{5}=\mathrm{OH}, \mathrm{R}_{6}=$

$\mathrm{H}, \mathrm{R}_{7}=\mathrm{H}$

$633 \mathrm{R}_{1}=\alpha$-L-arabinopyranoside, $\mathrm{R}_{2}=\mathrm{H}, \mathrm{R}_{3}=\mathrm{CH}_{3}, \mathrm{R}_{4}=\mathrm{H}, \mathrm{R}_{5}=\mathrm{OH}, \mathrm{R}_{6}=\mathrm{H}, \mathrm{R}_{7}=\mathrm{H}$

$642 R_{1}=6$ '-desoxy- $\beta$-D-allopyranosyl-4'- $\beta$-D-xylopyranosyl-3"- $\beta$-D-apiofuranoside, $R_{2}=H, R_{3}$

$=\mathrm{CHO}, \mathrm{R}_{4}=\mathrm{OH}, \mathrm{R}_{5}=\mathrm{H}, \mathrm{R}_{6}=\mathrm{H}, \mathrm{R}_{7}=\mathrm{H}$

$643 \mathrm{R}_{1}=\alpha$-L-rhamopyranosyl-4'- $\beta$-D-apiofuranoside, $\mathrm{R}_{2}=\mathrm{H}, \mathrm{R}_{3}=\mathrm{CH}_{3}, \mathrm{R}_{4}=\mathrm{H}, \mathrm{R}_{5}=\mathrm{H}, \mathrm{R}_{6}=\mathrm{H}$,

$\mathrm{R}_{7}=\mathrm{OH}$

$644 R_{1}=\beta$-D-digitoxopyranosyl-4'- $\beta$-D-xylpyranosyl-3"- $\beta$-D-apiofuranoside, $R_{2}=H, R_{3}=C_{3}, R_{4}$

$=H, R_{5}=H, R_{6}=H, R_{7}=O A C$

$645 R_{1}=2^{\prime}$-desoxy- $\beta$-D-allopyranosyl-4'- $\beta$-D-xylopyranosyl-3"- $\beta$-D-apiofuranoside , $R_{2}=H, R_{3}=$

$\mathrm{CH}_{3}, \mathbf{R}_{4}=\mathrm{H}_{1} \mathbf{R}_{5}=\mathrm{H}, \mathbf{R}_{6}=\mathrm{H}, \mathbf{R}_{7}=\mathrm{OAC}$

$646 R_{1}=\beta$-D-digitoxopyranosyl-4'- $\beta$-D-xylpyranosyl-3"- $\beta$-D-apiofuranoside, $R_{2}=H, R_{3}=C_{3}, R_{4}$

$=\mathrm{H}, \mathrm{R}_{5}=\mathrm{H} \mathrm{R}_{6}=\mathrm{OH}, \mathrm{R}_{7}=\mathrm{OAC}$

$653 \mathrm{R}_{1}=6$ - desoxy- $\alpha$-L-glucopyranoside, $\mathrm{R}_{2}=\mathrm{H}, \mathrm{R}_{3}=\mathrm{CHO}, \mathrm{R}_{4}=\mathrm{OH}, \mathrm{R}_{5}=\mathrm{H}_{1} \mathrm{R}_{6}=\mathrm{H}, \mathrm{R}_{7}=\mathrm{H}$

$654 R_{1}=\alpha$-L-rhamnopyranosyl- $\beta$-D-glucopyranoside, $R_{2}=H, R_{3}=C H O, R_{4}=O H, R_{5}=H, R_{6}$

$=\mathrm{H}, \mathrm{R}_{7}=\mathrm{H}$

$655 R_{1}=\beta$-D-allopyranosyl- $\beta$-D-xyloside, $R_{2}=H, R_{3}=C H O, R_{4}=O H, R_{5}=H, R_{6}=H, R_{7}=H$

$656 R_{1}=\beta$-D-digitoxopyranosyl-4'-glucopyranoside, $R_{2}=H, R_{3}=H, R_{4}=O H, R_{5}=H, R_{6}=H$,

$\mathrm{R}_{7}=\mathrm{H}$

$657 \mathrm{R}_{1}=\alpha$-L-rhamnopyranoside, $\mathrm{R}_{2}=\mathrm{H}, \mathrm{R}_{3}=\mathrm{CHO}, \mathrm{R}_{4}=\mathrm{OH}, \mathrm{R}_{5}=\mathrm{OH}, \mathrm{R}_{6}=\mathrm{H}, \mathrm{R}_{7}=\mathrm{H}$

$658 \mathrm{R}_{1}=6$ - desoxy- $\alpha$-L-glucopyranoside, $\mathrm{R}_{2}=\mathrm{H}, \mathrm{R}_{3}=\mathrm{CHO}, \mathrm{R}_{4}=\mathrm{OH}, \mathrm{R}_{5}=\mathrm{OH}, \mathrm{R}_{6}=\mathrm{H}, \mathrm{R}_{7}=\mathrm{H}$

$659 \mathrm{R}_{1}=\alpha$-L-rhamnopyranosyl-4'- $\beta$-D-apiofuranoside, $\mathrm{R}_{2}=\mathrm{H}, \mathrm{R}_{3}=\mathrm{CH}_{3}, \mathrm{R}_{4}=\mathrm{H}, \mathrm{R}_{5}=\mathrm{OH}, \mathrm{R}_{6}=$

$\mathrm{H}, \mathrm{R}_{7}=\mathrm{H}$

$660 \mathrm{R}_{1}=\alpha$-L-rhamnopyranosyl-4'- $\alpha$-L-rhamnopyranoside, $\mathrm{R}_{2}=\mathrm{H}, \mathrm{R}_{3}=\mathrm{CH}_{3}, \mathrm{R}_{4}=\mathrm{H}, \mathrm{R}_{5}=\mathrm{OH}$,

$\mathrm{R}_{6}=\mathrm{H}, \mathrm{R}_{7}=\mathrm{H}$

$661 R_{1}=\beta$-D-digitoxpyranosyl- $\beta$-D-xylpyranosyl- $\alpha$-L-rhamnopyranoside, $R_{2}=H_{2} R_{3}=C_{3}, R_{4}=$ $\mathrm{H}, \mathrm{R}_{5}=\mathrm{OH}, \mathrm{R}_{6}=\mathrm{H}, \mathrm{R}_{7}=\mathrm{H}$

$662 \mathbf{R}_{1}=\alpha$-L-rhamnopyranoside, $\mathbf{R}_{2}=\mathrm{H}, \mathbf{R}_{3}=\mathrm{CH}_{3}, \mathbf{R}_{4}=\mathrm{OH}, \mathbf{R}_{5}=\mathrm{OH}, \mathrm{R}_{6}=\mathrm{H}, \mathrm{R}_{7}=\mathrm{H}$

$663 \mathrm{R}_{1}=\beta$-D-glucopyranoside, $\mathrm{R}_{2}=\mathrm{H}, \mathrm{R}_{3}=\mathrm{CH}_{3}, \mathrm{R}_{4}=\mathrm{OH}, \mathrm{R}_{5}=\mathrm{OH}, \mathrm{R}_{6}=\mathrm{H}, \mathrm{R}_{7}=\mathrm{H}$

$664 R_{1}=$ 2-desoxy- $\beta$-D-allopyranoside, $R_{2}=O H, R_{3}=C_{3}, R_{4}=O H, R_{5}=O H, R_{6}=H, R_{7}=H$<smiles>O=c1cc(-c2ccc(O)cc2)oc2cc(O)cc(O)c12</smiles>

627<smiles>O=c1cc(-c2ccc(O)c(O)c2)oc2cc(O)cc(O)c12</smiles>

628<smiles>[R6]c1cc2oc(-c3ccc(O)cc3)cc(=O)c2c(O)c1[R2]</smiles>

$629 \mathrm{R}=\beta$-D-glucopyranoside
$630 R_{1}=\beta$-D-glucopyranoside, $R_{2}=\beta$-Dglucopyranosyl- $\beta$-D-glucopyranoside 


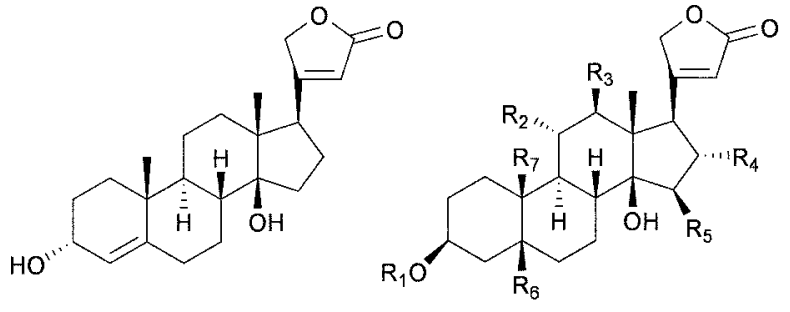

634

$635 R_{1}=\alpha$-L-rhamnopyranoside, $R_{2}=H, R_{3}=H, R_{4}=\beta$ -

$\mathrm{OH}, \mathrm{R}_{5}=\mathrm{H}, \mathrm{R}_{6}=\mathrm{H}, \mathrm{R}_{7}=\mathrm{CH}_{3}$

$665 R_{1}=H, R_{2}=O H, R_{3}=H, R_{4}=H, R_{5}=H, R_{6}=H, R_{7}=$ $\mathrm{CH}_{3}$

$666 \mathrm{R}_{1}=6$ '-deoxy- $\beta$-D-allpyranosyl- $\beta$-D-xylopyranosyl- $\alpha$-Lrhamnoside, $\mathrm{R}_{2}=\mathrm{OH}, \mathrm{R}_{3}=\mathrm{H}, \mathrm{R}_{4}=\mathrm{H}, \mathrm{R}_{5}=\mathrm{H}, \mathrm{R}_{6}=\mathrm{H}, \mathrm{R}_{7}$ $=\mathrm{CH}_{3}$

$667 R_{1}=6$ '-deoxy- $\beta$-D-allopyranosyl- $\beta$-D-xylpyranosyl- $\beta$-Dapiofuranoside, $R_{2}=O H, R_{3}=H, R_{4}=H, R_{5}=H, R_{6}=H$, $\mathrm{R}_{7}=\mathrm{CH}_{3}$

$668 R_{1}=\beta$-D-digitoxopyranosyl- $\beta$-D-xylpyranosyl- $\alpha$-Lrhamnopyranoside, $\mathrm{R}_{2}=\mathrm{H}, \mathrm{R}_{3}=\mathrm{H}, \mathrm{R}_{4}=\mathrm{OH}, \mathrm{R}_{5}=\mathrm{OH}, \mathrm{R}_{6}$ $=\mathrm{H}_{1} \mathrm{R}_{7}=\mathrm{CH}_{3}$

$669 R_{1}=\beta$-D-digitoxpyranosyl- $\beta$-D-xylpyranosyl- $\beta$-Dapiofuranoside, $R_{2}=O H, R_{3}=H, R_{4}=H, R_{5}=H, R_{6}=H$, $\mathrm{R}_{7}=\mathrm{CH}_{3}$

$670 R_{1}=\beta$-D-digitoxopyranosyl- $\beta$-D-xylopyranosyl- $\alpha$-Lrhamnopyranoside, $\mathrm{R}_{2}=\mathrm{H}, \mathrm{R}_{3}=\mathrm{OH}, \mathrm{R}_{4}=\mathrm{H}, \mathrm{R}_{5}=\mathrm{H}, \mathrm{R}_{6}=$ $\mathrm{H}, \mathrm{R}_{7}=\mathrm{CH}_{3}$

$671 R_{1}=\alpha$-L-rhamnopyranosyl- $\beta$-D-apiofuranoside, $R_{2}=$

$\mathrm{OH}_{1} \mathrm{R}_{3}=\mathrm{H}, \mathrm{R}_{4}=\mathrm{H}, \mathrm{R}_{5}=\mathrm{H}, \mathrm{R}_{6}=\mathrm{H}, \mathrm{R}_{7}=\mathrm{CH}_{3}$

$672 R_{1}=\beta$-D-digitoxopyranosyl- $\beta$-D-xylopyranosyl- $\alpha$ - Lrhamnopyranoside, $\mathrm{R}_{2}=\mathrm{H}, \mathrm{R}_{3}=\mathrm{H}, \mathrm{R}_{4}=\mathrm{H}, \mathrm{R}_{5}=\mathrm{H}, \mathrm{R}_{6}=$ $\mathrm{H}, \mathrm{R}_{7}=\mathrm{CH}_{3}$

$673 R_{1}=6^{\prime}$-deoxy- $\beta$-D-allopyranosyl- $\beta$ - $D$-xylopyranoside, $R_{2}=H, R_{3}=H, R_{4}=H, R_{5}=H_{1} R_{6}=H_{1} R_{7}=C_{3}$ $677 R_{1}=H, R_{2}=H, R_{3}=H, R_{4}=H, R_{5}=H, R_{6}=O H, R_{7}=$ $\mathrm{CH}_{3}$

$678 R_{1}=H_{1} R_{2}=O H, R_{3}=H, R_{4}=H, R_{5}=H, R_{6}=O H$, $\mathrm{R}_{7}=\mathrm{CHO}$

$679 R_{1}=H_{1} R_{2}=O H, R_{3}=H, R_{4}=H, R_{5}=H, R_{6}=O H$, $\mathrm{R}_{7}=\mathrm{CH}_{3}$

$680 R_{1}=H_{1} R_{2}=H, R_{3}=H, R_{4}=H_{3} R_{5}=H, R_{6}=O_{3} R_{7}$ $=\mathrm{CH}_{2} \mathrm{OH}$

$681 R_{1}=6$-deoxy- $\beta$-D-allopyranoside, $R_{2}=H_{2} R_{3}=H, R_{4}$ $=\mathrm{H}, \mathrm{R}_{5}=\mathrm{H}, \mathrm{R}_{6}=\mathrm{OH}, \mathrm{R}_{7}=\mathrm{CH}_{3}$

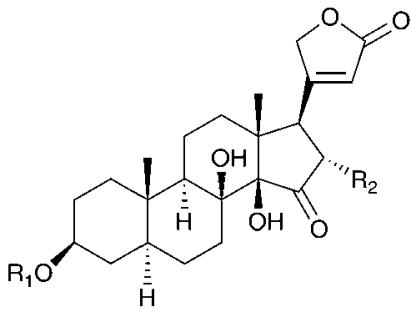

$637 R_{1}=\beta$-D-digitoxopyranosyl- $\beta-D-x y l o p y r a n o s y l-\alpha-L$ rhamnopyranoside, $\mathrm{R}_{2}=\mathrm{OH}$

$638 \mathrm{R}_{1}=3^{\prime}$-O-acetyl- $\beta$-D-digitoxopyranosyl- $\beta$-Dxylopyranosyl- $\alpha$-L-rhamnopyranoside, $\mathrm{R}_{2}=\mathrm{OH}$ $639 R_{1}=\beta$-D-digitoxopyranosyl- $\beta$-D-xylopyranosyl- $\beta$-Dapiofuranoside, $R_{2}=\mathrm{H}$

$640 R_{1}=-3$ '-O-acetyl- $\beta$-D-digitoxopyranosyl- $\beta$-Dxylopyranosyl- $\alpha$-L-rhamnopyranoside, $R_{2}=H$

$641 R_{1}=\beta$-D-digitoxopyranosyl- $\beta$-D-xylopyranosyl- $\alpha-L$ rhamnopyranoside, $\mathrm{R}_{2}=\mathrm{H}$

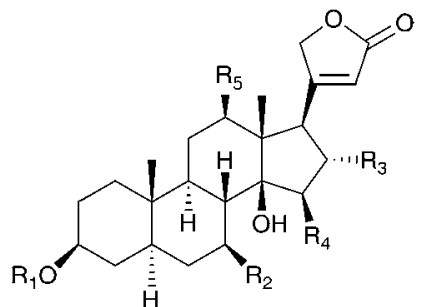

$636 R_{1}=\beta$-D-digitoxopyranosyl-4'- $\beta$-Dxylopyranosyl-4" $-\alpha-L-$

rhamnopyranoside, $\mathrm{R}_{2}=\mathrm{OH}, \mathrm{R}_{3}=\mathrm{OH}$ $\mathrm{R}_{4}=\mathrm{OH}, \mathrm{R}_{5}=\mathrm{H}$

$652 R_{1}=3^{\prime}-$ O-acetyl- $\beta$-D-

digitoxopyranosyl-4'- $\beta$-D-xylopyranosyl4 "- $\alpha$-L-rhamnopyranoside, $R_{2}=H, R_{3}=$ $\mathrm{H}, \mathrm{R}_{4}=\mathrm{H}, \mathrm{R}_{5}=\mathrm{OH}$

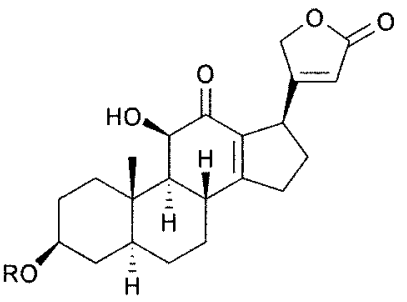

$647 R=3^{\prime}-O$-acetyl- $\beta$-D-digitoxopyranosyl-4' $-\beta-D$ xylopyranosyl-4"- $\alpha$-L-rhamnopyranoside $648 \mathrm{R}=\beta$-D-digitoxopyranosyl-4' $-\beta$-D-xylopyranosyl-4"$\alpha$-L-rhamnopyranoside $650 R=\beta$-D-digitoxopyranosyl-4'-B-D-xylopyranosyl-4"$\alpha$-L-rhamnopyranoside

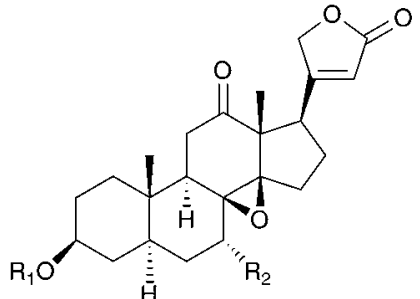

$649 R_{1}=3^{\prime}-O$-acetyl- $\beta$-D-digitoxopyranosyl-4'- $\beta$-Dxylopyranosyl-4"- $\alpha$-L-rhamnopyranoside $R_{2}=H$ $651 R_{1}=\beta$-D-digitoxopyranosyl-4' $-\beta$-D-

xylopyranosyl-4"- $\alpha$-L-rhamnopyranoside, $R_{2}=\mathrm{OH}$<smiles>[R]c1c(O)cc2oc(-c3ccc(O)cc3)cc(=O)c2c1[R]</smiles>

$674 \mathrm{R}_{1}=\beta$-D-glucopyranoside, $\mathrm{R}_{2}=\mathrm{OH}$ $675 \mathrm{R}_{1}=\mathrm{OH}, \mathrm{R}_{2}=\beta$-D-glucopyranoside 
cytotoxicity against leukemia HL-60 cells $\left(\mathrm{IC}_{50}=0.79 \mu \mathrm{g} \mathrm{ml}{ }^{-1}\right)$, fractionation of this extract resulted in the isolation of twelve bisdesmosidic cholestane glycosides (577-578, 686-694), ${ }^{397}$ seven cholestane glycosides (695-701) and nine spirocyclic glycosides (702-710). ${ }^{\text {398,399 }}$ The bisdesmosidic cholestane glycosides with an aromatic acyl group at the C-16 diglycoside were found to be the most cytotoxic (686 and 576) with $\mathrm{IC}_{50}$ values of 0.00016 and $0.00013 \mu \mathrm{g} \mathrm{ml}^{-1}$ respectively. Compounds 687 and 696, the deacyl derivatives of compounds 688 and 689 and compounds 691 and 692 respectively did not show any activity at all. ${ }^{400}$ Only moderate activity against leukemia HL-60 cells was found for the spirocyclic glycosides $\left(\mathrm{IC}_{50}\right.$ of 1.6-5.3 $\mu \mathrm{g}$ $\left.\mathrm{ml}^{-1}\right){ }^{401}$ An arabinoglucuronomannoglycan has been isolated from the leaves of E. thyrsoides (as O. thyrsoides). ${ }^{\mathbf{4 0 2}}$ South African bulbs of Stellarioides longibracteata (Jacq.) Speta are used extensively by the Zulu as an anti-inflammatory, and regionally to treat diabetes. A phytochemical investigation of the bulbs (as Ornithogalum longibracteatum Jacq.) revealed one major compound, the homoisoflavanone $\mathbf{7 1 1 .}^{\mathbf{4 0 3}}$ The water extract of the bulbs produced a significant increase in glucose utilisation in Chang liver cells. ${ }^{404}$ Stellarioides longibracteata was introduced to China many years ago and it is used in Chinese folk medicine to treat cancer, as an antimicrobial, anti-inflammatory and to treat hepatitis and parotitis. ${ }^{\mathbf{4 0 5}}$ This species was known earlier as Ornithogalum caudatum Ait. and as such many papers and in particular patents, have been filed under that name. Spirosterols, caudaside A $\mathbf{7 1 2}$ and hecogenin $\mathbf{7 1 3}$ have been isolated as well as $\beta$-sitosterol ${ }^{406}$ and three homoisoflavanones (714-716). ${ }^{407}$ Compounds 714-716 were tested for anti-tumour activity against P388 (mouse leukemia) and A-549

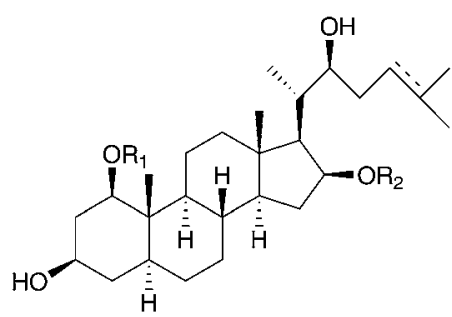

$682 \mathrm{R}_{1}=\alpha$-L-rhamnopyranoside, $\mathrm{R}_{2}=\beta$-D-glucopyranoside

$683 \mathrm{R}_{1}=\alpha$-L-rhamnopyranoside, $\mathrm{R}_{2}=6$ - $O$-acetyl- $\beta$-D-glucopyranoside

$684 R_{1}=\alpha$-L-rhamnopyranoside, $R_{2}=\beta$-D-glucopyranoside, $\Delta^{24}$

$685 R_{1}=\alpha$-L-rhamnopyranoside, $R_{2}=6$-O-acetyl- $\beta$-D-glucopyranoside, $\Delta^{24}$

$695 R_{1}=\alpha$-L-rhamnopyranoside, $R_{2}=\beta$-apiofuranosyl- 6 - $O$-acetyl- $\beta$-D-

glucopyranoside

$696 \mathrm{R}_{1}=\beta$-D-glucopyranoidel, $\mathrm{R}_{2}=\beta$-D-glucopyranoside

$697 R_{1}=6-O-3,4,5$-trimethoxybenzoyl- $\beta$-D-glucopyranoside, $R_{2}=\beta-D$ glucopyranoside

$698 \mathrm{R}_{1}=6-0-3,4,5$-trimethoxybenzoyl- $\beta$-D-glucopyranoside, $R_{2}=\beta$-Dglucopyranoside, $\Delta^{24}$

$699 R_{1}=\alpha$-L-rhamnopyranoside, $R_{2}=\alpha$-L-rhamnopyranoside, $\Delta^{5}$

$700 R_{1}=\alpha$-L-rhamnopyranoside, $R_{2}=\alpha$-L-rhamnopyranoside, $\Delta^{24}$

$701 R_{1}=\alpha$-L-rhamnopyranoside, $R_{2}=\alpha$-L-rhamnopyranoside $, \Delta^{5}, \Delta^{24}$

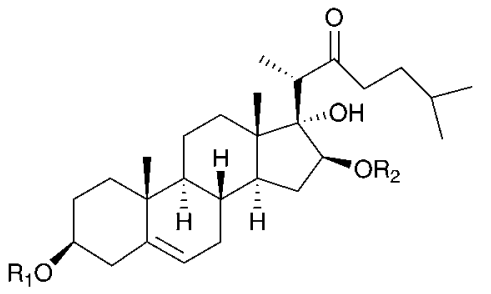

$686 \mathrm{R}_{1}=\beta$-D-glucopyranoside, $\mathrm{R}_{2}=2-0-3,4,5$-trimethoxybenzoyl- $\beta$-Dxylopyranosyl-2-O-acetyl- $(1 \rightarrow 3)$ - $\alpha$-L-arabinopyranoside

$687 \mathrm{R}_{1}=\beta$-D-glucopyranosyl- $(1 \rightarrow 6)-\beta$-D-glucopyranoside, $\mathrm{R}_{2}=\beta$-D-xylopyranosyl2-O-acetyl- $(1 \rightarrow 3)$ - $\alpha$-L-arabinopyranoside

$688 \mathrm{R}_{1}=\beta$-D-glucopyranosyl- $(1 \rightarrow 6)-\beta$-D-glucopyranoside, $\mathrm{R}_{2}=2-\mathrm{O}-3,4-$

dimethoxybenzoyl- $\beta$-D-xylopyranosyl-2-O-acetyl- $(1 \rightarrow 3)$ - $\alpha$-L-arabinopyranoside

$689 \mathrm{R}_{1}=\beta$-D-glucopyranosyl- $(1 \rightarrow 6)-\beta$-D-glucopyranoside, $\mathrm{R}_{2}=2-0-3,4,5-$

trimethoxybenzoyl- $\beta$-D-xylopyranosyl-2-O-acetyl- $(1 \rightarrow 3)$ - $\alpha$-L-arabinopyranoside

$690 \mathrm{R}_{1}=\beta$-D-glucopyranosyl- $(1 \rightarrow 4)-\beta$-D-glucopyranosyl- $(1 \rightarrow 6)-\beta-\mathrm{D}-$

glucopyranoside, $R_{2}=\beta$-D-xylopyranosyl-2-O-acetyl- $(1 \rightarrow 3)$ - $\alpha$-L-arabinopyranoside

$691 R_{1}=\beta$-D-glucopyranosyl- $(1 \rightarrow 4)-\beta$-D-glucopyranosyl- $(1 \rightarrow 6)-\beta-D$ -

glucopyranoside, $\mathrm{R}_{2}=2-0$-3,4-dimethoxybenzoyl- $\beta$-D-xylopyranosyl-2-O-acetyl$(1 \rightarrow 3)-\alpha$-L-arabinopyranoside

$692 \mathrm{R}_{1}=\beta$-D-glucopyranosyl- $(1 \rightarrow 4)-\beta$-D-glucopyranosyl- $(1 \rightarrow 6)-\beta$-D-

glucopyranoside, $\mathrm{R}_{2}=2-0-3,4,5$-trimethoxybenzoyl- $\beta$-D-xylopyranosyl-2-O-acetyl$(1 \rightarrow 3)$ - $\alpha$-L-arabinopyranoside

$693 \mathrm{R}_{1}=\beta$-D-glucopyranosyl- $(1 \rightarrow 4)-\beta$-D-glucopyranosyl- $(1 \rightarrow 6)-\beta-D$ -

glucopyranoside, $R_{2}=2-O-4$-hydroxy-3-methoxybenzoyl- $\beta$-D-xylopyranosyl-2- $O$ acetyl- $(1 \rightarrow 3)-\alpha$-L-arabinopyranoside

$694 R_{1}=\beta$-D-glucopyranosyl- $(1 \rightarrow 4)-\beta$-D-glucopyranosyl- $(1 \rightarrow 6)-\beta$-D-

glucopyranoside, $\mathrm{R}_{2}=3-0-3,4$-dimethoxybenzoyl- $\beta$-D-xylopyranosyl-2-O-acetyl$(1 \rightarrow 3)$ - $\alpha$-L-arabinopyranoside

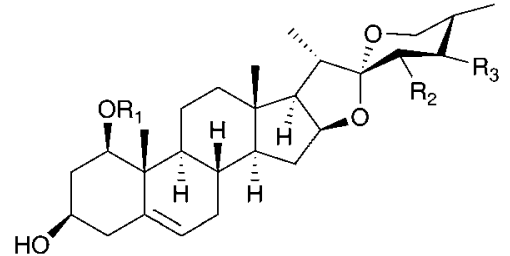

$702 R_{1}=\beta$-D-glucopyranoside, $R_{2}=H, R_{3}=H$

$703 \mathrm{R}_{1}=\alpha$-L-rhamnopyranosyl- $(1 \rightarrow 2)-\alpha$-L-arabinopyranoside, $\mathrm{R}_{2}=\mathrm{H}, \mathrm{R}_{3}=\mathrm{H}$

$704 \mathrm{R}_{1}=\alpha$-L-rhamnopyranosyl- $(1 \rightarrow 2)$-[ $\beta$-D-xylopyranosyl-

$(1 \rightarrow 3)$ - $\alpha$-L-arabinopyranoside, $\mathrm{R}_{2}=\mathrm{H}, \mathrm{R}_{3}=\mathrm{H}$

$705 \mathrm{R}_{1}=\alpha$-L-rhamnopyranosyl- $(1 \rightarrow 2)$ - $\alpha$-L-arabinopyranoside,

$\mathrm{R}_{2}=\mathrm{H}, \mathrm{R}_{3}=\mathrm{OH}$

$706 \mathrm{R}_{1}=\alpha$-L-rhamnopyranosyl- $(1 \rightarrow 2)-[\beta-\mathrm{D}$-xylopyranosyl-

$(1 \rightarrow 3)$ - $\alpha$-L-arabinopyranoside, $\mathrm{R}_{2}=\mathrm{H}, \mathrm{R}_{3}=\mathrm{OH}$

$712 \mathrm{R}_{1}=\alpha$-L-rhamnopyranosyl- $(1 \rightarrow 2)-[\beta$-D-xylopyranosyl-

$(1 \rightarrow 3)-\alpha$-L-arabinopyranoside, $\mathrm{R}_{2}=\mathrm{OH}, \mathrm{R}_{3}=\mathrm{OH}$

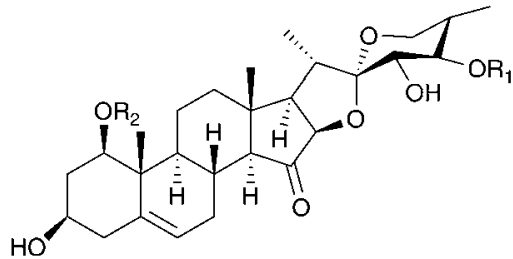

$707 \mathrm{R}_{1}=\mathrm{H}, \mathrm{R}_{2}=\alpha$-L-rhamnopyranosyl- $(1 \rightarrow 2)-\alpha-L-$ arabinopyranoside

$708 R_{1}=6$-deoxy- $\beta$-D-gulopyranoside, $R_{2}=\alpha$ - L-

rhamnopyranosyl- $(1 \rightarrow 2)$ - $\alpha$-L-arabinopyranoside

$709 R_{1}=6$-deoxy- $\beta$-D-gulopyranoside, $R_{2}=[\alpha-L-$

rhamnopyranosyl-(1 $\rightarrow 2)-O-[-\beta-D-x y l o p y r a n o s y l-(1 \rightarrow 3)]-\alpha-L$

arabinopyranoside

$710 R_{1}=6$-deoxy- $\beta$-D-gulopyranoside, $R_{2}=[2,3,4$ - tri-O-

acetyl- $\alpha$-L-rhamnopyranosyl-( $1 \rightarrow 2)$-O-[- $\beta$-D-xylopyranosyl-

$(1 \rightarrow 3)]-\alpha-L$-arabinopyranoside 

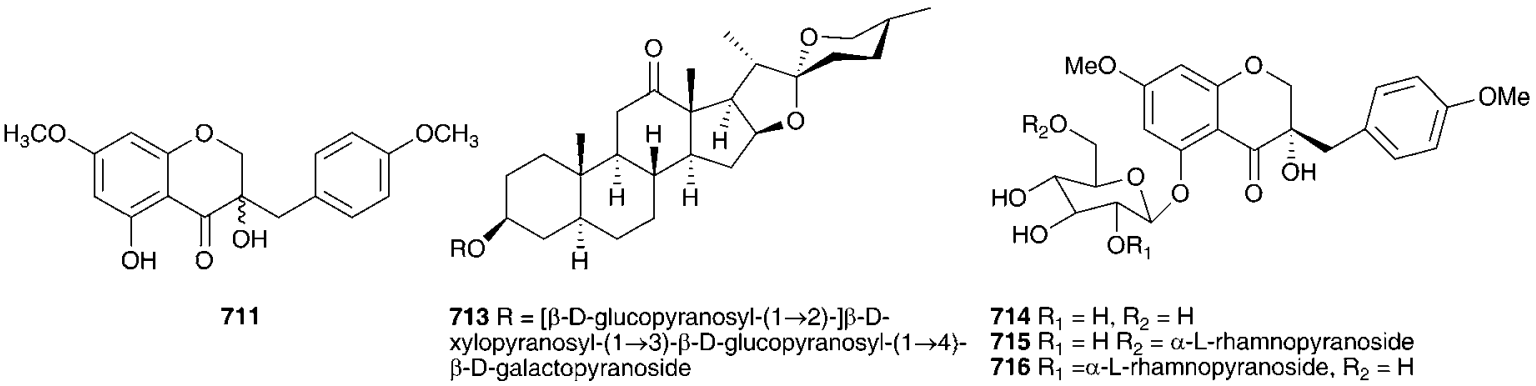

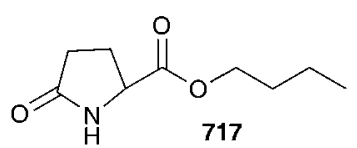

(human pulmonary adenocarcinoma) but no activities were noted. Later investigations of the bulbs of $S$. longibracteata (as O. caudatum) resulted in the isolation of $n$-butyl pyroglumate 717, 26 additional known flavonoids, sterols and acids ${ }^{\mathbf{4 0 8}}$ and a monoterpene lactone (6-hydroxy-4,4,7 $\alpha$-trimethyl-5,6,7,7 $\alpha$-tetrahydro- $4 H$-benzofuran-2-one). ${ }^{409}$ A number of patents have been filed in China and Russia outlining methods for the extraction of $S$. longibracteata (as $O$. caudatum) and use as a treatment for cancer, ${ }^{\mathbf{4 1 0 , 4 1 1}}$ cholecystitis and cholecystitis-related diseases $^{\mathbf{4 1 2}}$ and for the isolation of the flavonoid components for use as an anti-inflammatory and analgesic. ${ }^{\mathbf{4 1 3 , 4 1 4}}$ Extracts from $S$. longibracteata (as O. caudatum) have shown some benefit in the treatment of liver conditions. ${ }^{\mathbf{4 1 5 , 4 1 6}}$ Four water soluble polysaccharide fractions have been extracted from $S$. longibracteata (as O. caudatum) and have been found to have potential as antitumour agents. ${ }^{417-419}$ Further work on the anti-cancer effects of this species has shown inhibition of MDA-MB-231 breast cancer cells in a dose and time dependant manner. ${ }^{\mathbf{4 2 0}}$ The bulbs of Stellarioides tenuifolia (Redoute) Speta (as Ornithogalum tenuifolium Delaroche) yielded a crystalline steroidal saponin, 718, with an unusual $5 \beta$ configuration. ${ }^{\mathbf{4 2 1}}$ This unusual configuration at $\mathrm{C}-5$, together with the $1 \beta, 3 \alpha$ hydroxyl group configuration, results in a molecule with a shape that is able to undergo selfrecognition, similar to single-strand DNA, and thus form a supramolecular zipper.

A review of steroidal glycosides isolated from various monocot families (including Galtonia saundersiae, as Ornithogalum saundersiae) and their biological activities has been published as well as a review of cholestane glycosides from $G$. saundersiae, G. candicans and Eliokarmos thyrsoides (as Ornithogalum thyrsoides). ${ }^{\mathbf{4 2 2 , 4 2 3}}$

\section{The Oziroëoideae}

The genus Ozirö̈ Raf. (syn. Fortunatia Macbr.), is widespread in South America and can be found in Peru, Chile, Bolivia, Paraguay and north to central Argentina. ${ }^{\mathbf{4 2 4}}$ No phytochemical investigations have been recorded on these plant species.

\section{Conclusions}

Research into the chemistry of the Hyacinthaceae has spanned over 90 years and resulted in the isolation of over 700 compounds. The need to understand the chemistry was largely fuelled by both the toxicity of the plants to stock and the significant ethnomedicinal applications associated with representative species. In addition to the isolation of many compounds of medicinal significance, the phytochemical studies have shed light on the classification of many of the species. A thorough understanding of the chemistry and pharmacology of these important plant species allows for the potential discovery of new medical applications and further aids the conservation of those taxa threatened with unsustainable utilisation by indicating alternatives with similarly active constituents.

\section{Acknowledgements}

This review was initiated during a Rockefeller Foundation Bellagio Academic Writing Residency, which Dulcie Mulholland gratefully acknowledges. Dr Mario Martínez-Azorín of CIBIO at the Universidad de Alicante, Spain, kindly commented on taxonomic queries, particularly with respect to the Ornithogaloideae; the third author (Neil Crouch), however, takes responsibility for final decisions on current names, and their relation to synonyms.

\section{References}

1 T. S. Pohl, N. R. Crouch and D. A. Mulholland, Curr. Org. Chem., 2000, 4, 1287-1324.

2 Angiosperm Phylogeny Group, Bot. J. Linn. Soc., 2003, 141, 399-436.

3 Angiosperm Phylogeny Group, Bot. J. Linn. Soc., 2009, 161, 105-121.

4 M. Pfosser and F. Speta, Ann. Mo. Bot. Gard., 1999, 86, 852875. 
5 F. Speta, The Families and Genera of Vascular Plants, Springer, Berlin, 1998, vol. 3, pp. 261-285.

6 M. Martínez-Azorín, B. Crespo Manuel, A. Juan and M. F. Fay, Ann. Bot., 2011, 107, 1-37.

7 S. Ali Syed, Y. Yu, M. Pfosser and W. Wetschnig, Ann. Bot., 2012, 109, 95-107.

8 M. W. Chase, J. L. Reveal and M. F. Fay, Bot. J. Linn. Soc., 2009, 161, 132-136.

9 B. M. Abegaz, J. Mutanyatta and M. Nindi, Nat. Prod. Commun., 2007, 2, 475-498.

10 K. du Toit, S. E. Drewes and J. Bodenstein, Nat. Prod. Res., 2010, 24, 457-490.

11 W. Heller and C. H. Tamm, Fortschr. Chem. Org. Naturst., 1979, 40, 106-136.

12 P. Boehler and C. H. Tamm, Tetrahedron Lett., 1967, 8, 3479-3483.

13 H. P. Weber, Helv. Chim. Acta, 1977, 60, 1288-1392.

14 C. H. Tamm, Arzneim. Forsch., 1972, 22, 1776-1784.

15 W. Heller, P. Andermatt, W. A. Schaad and C. H. Tamm, Helv. Chim. Acta, 1976, 59, 2048-2058.

16 Y. Mimaki, K. Ori, S. Kubo, Y. Sashida, T. Nikaido, L. G. Song and T. Ohmoto, Chem. Lett., 1992, 1863-1866.

17 Y. Mimaki, H. Nishino, K. Ori, M. Kuroda, T. Matsui and Y. Sashida, Chem. Pharm. Bull., 1994, 42, 327-332.

18 J. K. Sihra, PhD Thesis, University of Surrey, 2012.

19 S. Koduru, D. S. Grierson and A. J. Afolayan, Curr. Sci., 2007, 92, 906-908.

20 R. Williams, N. R. Crouch and G. Pettit, ISBA Bulletin, 1996, 44, 26-31.

21 W. T. L. Sidwell and C. H. Tamm, Tetrahedron Lett., 1970, 11, 475-478.

22 L. Farkas, A. Gottsegen, M. Nogradi and J. Strelisky, Tetrahedron, 1971, 27, 5049-5056.

23 W. T. L. Sidwell, H. Fritz and C. H. Tamm, Helv. Chim. Acta, 1971, 54, 207-215.

24 R. Ziegler and C. H. Tamm, Helv. Chim. Acta, 1976, 59, 1997-2011.

25 D. A. Mulholland, C. Koorbanally, N. R. Crouch and P. Sandor, J. Nat. Prod., 2004, 67, 1726-1728.

26 W. T. L. Sidwell, C. H. Tamm, R. Ziegler, J. Finer and J. Clardy, J. Am. Chem. Soc., 1975, 97, 3518-3519.

27 J. L. S. Taylor and J. van Staden, S. Afr. J. Bot., 2002, 68, 8085.

28 A. K. Jager, A. Hutchings and J. van Staden, J. Ethnopharmacol., 1996, 52, 95-100.

29 J. L. S. Taylor and J. van Staden, J. Ethnopharmacol., 2001, 75, 257-265.

30 A. K. Jager and J. van Staden, Phytochem. Rev., 2005, 4, 3946.

31 M. Gaidamashvili and J. van Staden, S. Afr. J. Bot., 2006, 72, 661-663.

32 M. Gaidamashvili and J. van Staden, J. Ethnopharmacol., 2002, 80, 131-135.

33 A. R. Ndhlala, R. B. Mulaudzi, M. G. Kulkarni and J. Van Staden, S. Afr. J. Bot., 2012, 79, 1-8.

34 J. L. S. Taylor and J. van Staden, S. Afr. J. Bot., 2002, 68, 157162.
35 J. L. S. Taylor and J. Van Staden, Plant Growth Regul., 2001, 34, 39-47.

36 R. E. Finckh and C. H. Tamm, Experientia, 1970, 26, 472473.

37 W. Heller and C. H. Tamm, Helv. Chim. Acta, 1974, 57, 17661784.

38 W. Heller and C. H. Tamm, Helv. Chim. Acta, 1978, 61, 12571261.

39 N. A. Koorbanally, N. R. Crouch, A. Langois, K. Du Toit, D. A. Mulholland and S. E. Drewes, S. Afr. J. Bot., 2006, 72, 428-433.

40 N. A. Koorbanally, N. R. Crouch, A. Harilal, B. Pillay and D. A. Mulholland, Biochem. Syst. Ecol., 2006, 34, 114-118.

41 K. Du Toit, E. E. Elgorashi, S. F. Malan, D. A. Mulholland, S. E. Drewes and J. Van Staden, S. Afr. J. Bot., 2007, 73, 236-241.

42 J. K. Sihra, PhD Thesis, University of Surrey, Guildford, UK, 2012.

43 I. Masterova, V. Suchy, D. Uhrin, K. Ubik, Z. Grancaiova and B. Bobovnicky, Phytochemistry, 1991, 30, 713-714.

44 E. Miadokova, I. Masterova, V. Vlckova, V. Duhova and J. Toth, J. Ethnopharmacol., 2002, 81, 381-386.

45 I. Juranek, V. Suchy, D. Stara, I. Masterova and Z. Grancaiova, Die Pharmazie, 1993, 48, 310-311.

46 M. Urbancikova, I. Masterova and J. Toth, Fitoterapia, 2002, 73, 724-726.

47 M. Ellnain-Wojtaszek, Z. Kowalewski and L. Skrzypczakowa, Ann. Pharm. (Poznan), 1978, 13, 171-175.

48 M. Adinolfi, M. M. Corsaro, R. Lanzetta, G. Laonigro, L. Mangoni and M. Parrilli, Phytochemistry, 1986, 26, 285290.

49 Z. Grancaiova, I. Materova and V. Suchy, Fitoterapia, 1992, 63, 380 .

50 M. Adinolfi, G. Barone, M. M. Corsaro, L. Mangoni, R. Lanzetta and M. Parrilli, Can. J. Chem., 1988, 66, 27872793.

51 N. Asano, H. Kuroi, K. Ikeda, H. Kizu, Y. Kameda, A. Kato, I. Adachi, A. A. Watson, R. J. Nash and G. W. J. Fleet, Tetrahedron: Asymmetry, 2000, 11, 1-8.

52 F. J. Arias, P. Antolin, C. de Torre, B. Barriuso, R. Iglesias, M. A. Rojo, J. Miguel Ferreras, E. Benvenuto, E. Mendez and T. Girbes, Int. J. Biochem. Cell Biol., 2003, 35, 61-78.

53 K. Yoshida, H. Aoki, K. Kameda and T. Kondo, ITE Lett. Batteries, New Technol. Med., 2002, 3, 35-38.

54 K. Ori, M. Koroda, Y. Mimaki, H. Sakagami and Y. Sashida, Phytochemistry, 2003, 64, 1351-1359.

55 M. Kuroda, Y. Mimaki, K. Ori, H. Sakagami and Y. Sashida, J. Nat. Prod., 2004, 67, 2099-2103.

56 V. V. Barbakadze, I. L. Targamadze and A. I. Usov, Bioorg. Khim., 1996, 22, 441-445.

57 V. Barbakadze and A. Usov, Bull. Georgian Natl. Acad. Sci., 2001, 163, 484-487.

58 G. Barone, M. M. Corsaro, R. Lanzetta and M. Parrilli, Phytochemistry, 1988, 27, 921-923.

59 O. Goktas, E. Ozen, E. Baysal, R. Mammadov and M. H. Alma, Wood Res. (Bratislava, Slovakia), 2010, 55, 5362. 
60 A. Kato, N. Kato, I. Adachi, J. Hollinshead, G. W. J. Fleet, C. Kuriyama, K. Ikeda, N. Asano and R. J. Nash, J. Nat. Prod., 2007, 70, 993-997.

61 C. P. Waller, PhD Thesis, University of Surrey, Guildford, UK, 2012.

62 J. W. C. Gunn, M. Goldberg and J. H. Ferguson, Trans. R. Soc. S. Afr., 1924, 12, 1-3.

63 D. A. Mulholland, N. R. Crouch, C. Koorbanally, N. Moodley and T. Pohl, Biochem. Syst. Ecol., 2006, 34, 251-255.

64 T. Pohl, PhD Thesis, University of Natal, South Africa, 2002.

65 T. Pohl, C. Koorbanally, N. R. Crouch and D. A. Mulholland, Biochem. Syst. Ecol., 2001, 29, 857-860.

66 S. G. Sparg, J. van Staden and A. K. Jager, J. Ethnopharmacol., 2002, 80, 95-101.

67 L. V. Buwa and J. van Staden, J. Ethnopharmacol., 2006, 103, 139-142.

68 C. P. Waller, A. E. Thumser, M. K. Langat, N. R. Crouch and D. A. Mulholland, Phytochemistry, 2013, in press.

69 C. Koorbanally, D. A. Mulholland and N. R. Crouch, Biochem. Syst. Ecol., 2006, 34, 588-592.

70 J. Mutanyatta, G. Matapa Bhagali, D. D. Shushu and M. B. Abegaz, Phytochemistry, 2003, 62, 797-804.

71 D. D. Shushu, J. Mutanyatta and B. M. Abegaz, J. Herbs, Spices Med. Plants, 2005, 11, 97-107.

72 B. M. Abegaz, Phytochem. Rev., 2002, 1, 299-310.

73 N. Moodley, N. R. Crouch, D. A. Mulholland, D. Slade and D. Ferreira, S. Afr. J. Bot., 2006, 72, 517-520.

74 I. Calvo Maria, Fitoterapia, 2009, 80, 394-398.

75 I. Calvo Maria, Fitoterapia, 2009, 80, 96-101.

76 M. Parrilli, R. Lanzetta, V. Dovinola, M. Adinolfi and L. Mangoni, Can. J. Chem., 1981, 59, 2261-2265.

77 J. Lietava, J. Ethnopharmacol., 1992, 35, 263-266.

78 A. Pieroni, V. Janiak, C. M. Durr, S. Ludeke, E. Trachsel and M. Heinrich, Phytother. Res., 2002, 16, 467-473.

79 M. R. Loizzo, R. Tundis, F. Menichini, A. Pugliese, M. Bonesi, U. Solimene and F. Menichini, Int. J. Food Sci. Nutr., 2010, 61, 780-791.

80 R. M. Mamedov and O. M. Gektash, Khim. Rastit. Syr'ya, 2011, 141-144.

81 M. Parrilli, M. Adinolfi, V. Dovinola and L. Mangoni, Gazz. Chim. Ital., 1979, 109, 391-393.

82 M. Parrilli, M. Adinolfi, V. Dovinola and L. Mangoni, Rend. Accad. Sci. Fis. Mat., Naples, 1979, 45, 527-532.

83 M. Parrilli, M. Adinolfi and L. Mangoni, Gazz. Chim. Ital., 1979, 109, 611-613.

84 M. Parrilli, R. Lanzetta, M. Adinolfi and L. Mangoni, Tetrahedron, 1980, 36, 3591-3596.

85 M. Adinolfi, G. Barone, R. Lanzetta, G. Laonigro, M. Parilli and L. Mangoni, Rend. Accad. Sci. Fis. Mat., Naples, 1983, 50, 295-296.

86 M. Adinolfi, G. Barone, R. Lanzetta, G. Laonigro, L. Mangoni and M. Parrilli, J. Nat. Prod., 1983, 46, 559562.

87 M. Adinolfi, G. Barone, R. Lanzetta, G. Laonigro, L. Mangoni and M. Parrilli, J. Nat. Prod., 1984, 47, 721-723.

88 M. Adinolfi, G. Barone, R. Lanzetta, G. Laonigro, L. Mangoni and M. Parrilli, J. Nat. Prod., 1984, 47, 544-546.
89 M. Adinolfi, G. Barone, R. Lanzetta, G. Laonigro, L. Mangoni and M. Parrilli, J. Nat. Prod., 1984, 47, 100-105.

90 M. Adinolfi, G. Barone, R. Lanzetta, G. Laonigro, M. Parrilli and L. Mangoni, Rend. Accad. Sci. Fis. Mat., Naples, 1983, 50, 293-294.

91 M. Adinolfi, G. Barone, M. M. Corsaro, R. Lanzetta, L. Mangoni and M. Parrilli, Can. J. Chem., 1987, 65, 23172326.

92 M. Adinolfi, G. Barone, R. Lanzetta, G. Laonigro, L. Mangoni and M. Parrilli, Can. J. Chem., 1983, 61, 26332637.

93 M. Adinolfi, G. Barone, R. Lanzetta, G. Laonigro, L. Mangoni and M. Parrilli, Can. J. Chem., 1984, 62, 12231226.

94 R. Lanzetta, G. Laonigro, M. Parrilli and E. Breitmaier, Can. J. Chem., 1984, 62, 2874-2878.

95 G. Barone, M. Belardini, R. Lanzetta, G. Laonigro and M. Parrilli, Rend. Accad. Sci. Fis. Mat., Naples, 1983, 50, 297-298.

96 M. Adinolfi, G. Barone, M. Belardini, R. Lanzetta, G. Laonigro and M. Parrilli, Phytochemistry, 1984, 23, 2091-2093.

97 M. Adinolfi, G. Barone, M. Belardini, R. Lanzetta, G. Laonigro and M. Parrilli, Phytochemistry, 1985, 24, 2423-2426.

98 M. Adinolfi, G. Barone, F. Giordano, R. Lanzetta and M. Parrilli, Tetrahedron, 1990, 46, 6565-6574.

99 M. Adinolfi, G. Barone, M. M. Corsaro, L. Mangoni, R. Lanzetta and M. Parrilli, Tetrahedron, 1988, 44, 49814988.

100 R. Della Loggia, P. Del Negro, A. Tubaro, G. Barone and M. Parrilli, Planta Med., 1989, 55, 587-588.

101 S. H. Hilal, M. M. Shabana and A. S. Ibrahim, Egypt. J. Pharm. Sci., 1985, 24, 67-74.

102 M. Guarrera Paolo, G. Salerno and G. Caneva, J. Ethnopharmacol., 2005, 99, 367-378.

103 C. L. Quave, L. R. W. Plano, T. Pantuso and B. C. Bennett, J. Ethnopharmacol., 2008, 118, 418-428.

104 Y. Mimaki, S. Kubo, Y. Kinoshita, Y. Sashida, L. G. Song, T. Nikaido and T. Ohmoto, Phytochemistry, 1993, 34, 791797.

105 G. Barone, M. M. Corsaro, R. Lanzetta, L. Mangoni and M. Parrilli, Phytochemistry, 1993, 33, 431-436.

106 K. Ori, M. Kuroda, Y. Mimaki, H. Sakagami and Y. Sashida, Chem. Pharm. Bull., 2003, 51, 92-95.

107 M. Adinolfi, M. M. Corsaro, R. Lanzetta, A. Mancino, L. Mangoni and M. Parrilli, Phytochemistry, 1993, 34, 773778.

108 M. Kuroda, Y. Mimaki, K. Ori, H. Koshino, T. Nukada, H. Sakagami and Y. Sashida, Tetrahedron, 2002, 58, 67356740.

109 M. M. Corsaro, R. Lanzetta, A. Mancino and M. Parrilli, Phytochemistry, 1992, 31, 1395-1397.

110 P. Baskaran, B. Ncube and J. van Staden, Plant Growth Regul., 2012, 67, 235-245.

111 C. Dias, J. A. Borralho Graca and M. Lurdes Goncalves, J. Ethnopharmacol., 2000, 71, 487-492. 
112 S.-M. Lee, H.-K. Chun, C.-H. Lee, B.-S. Min, E.-S. Lee and Y.-H. Kho, Chem. Pharm. Bull., 2002, 50, 1245-1249.

113 E.-J. Yeo, K.-T. Kim, Y. S. Han, S.-Y. Nah and H.-D. Paik, Food Sci. Biotechnol., 2006, 15, 639-642.

114 I. Kouno, N. Noda, Y. Ida, M. Sholichin, K. Miyahara, T. Komori and T. Kawasaki, Liebigs Ann. Chem., 1982, 306-314.

115 M. Sholichin, K. Miyahara and T. Kawasaki, Heterocycles, 1982, 17, 251-257.

116 M. Sholichin, K. Miyahara and T. Kawasaki, Chem. Pharm. Bull., 1985, 33, 1756-1759.

117 S.-M. Lee, H.-J. Lee, H.-K. Chun, C.-H. Lee, S.-J. Kang, H.-Y. Maeng and Y.-H. Kho, Saengyak Hakhoechi, 2001, 32, 189-192.

118 M. Ono, D. Toyohisa, T. Morishita, H. Horita, S. Yasuda, Y. Nishida, T. Tanaka, M. Okawa, J. Kinjo, H. Yoshimitsu and T. Nohara, Chem. Pharm. Bull., 2011, 59, 1348-1354.

119 I. Kouno, T. Komori and T. Kawasaki, Tetrahedron Lett., 1973, 14, 4569-4572.

120 Y. Nishida, M. Eto, H. Miyashita, T. Ikeda, K. Yamaguchi, H. Yoshimitsu, T. Nohara and M. Ono, Chem. Pharm. Bull., 2008, 56, 1022-1025.

121 H. B. Lee and S. M. Lee, KR Pat., 2010-35527, 2010.

122 H. G. Jun, Y. H. Ko, C. H. Lee, H. J. Lee and S. M. Lee, $K R$ Pat., 2001-1197, 2001.

123 M. T. Ono, Y. Takatsu, T. Ochiai, S. Yasuda, Y. Nishida, T. Tanaka, M. Okawa, J. Kinjo, H. Yoshimitsu and T. Nohara, Chem. Pharm. Bull., 2012, 60, 1314-1319.

124 T. Kurihara and H. Ito, Annu. Rep. Tohoku Coll. Pharm., 1968, 39-47.

125 A. I. Ismailov, Azerb. Med. Zh., 1961, 1, 57-60.

126 V. V. Barbakadze, I. L. Targamadze and A. I. Usov, Bioorg. Khim., 1996, 22, 58-61.

127 T. Yamashita, K. Yasuda, H. Kizu, Y. Kameda, A. Watson, R. J. Nash, G. W. J. Fleet and N. Asano, J. Nat. Prod., 2002, 65, 1875-1881.

128 Y. Mimaki, K. Ori, Y. Sashida, T. Nikaido, L. G. Song and T. Ohmoto, Bull. Chem. Soc. Jpn., 1993, 66, 1182-1186.

129 Y. Mimaki, K. Ori, Y. Sashida, T. Nikaido, L. G. Song and T. Ohmoto, Chem. Lett., 1992, 1999-2000.

130 N. Asano, K. Ikeda, M. Kasahara, Y. Arai and H. Kizu, J. Nat. Prod., 2004, 67, 846-850.

131 K. Hosokawa, Y. Fukunaga, E. Fukushi and J. Kawabata, Phytochemistry, 1995, 38, 1293-1298.

132 K. Hosokawa, Y. Fukunaga, E. Fukushi and J. Kawabata, Phytochemistry, 1996, 41, 1531-1533.

133 K. Hosokawa, Y. Fukunaga, E. Fukushi and J. Kawabata, Phytochemistry, 1995, 40, 567-571.

134 K. Hosokawa, Y. Fukunaga, E. Fukushi and J. Kawabata, Phytochemistry, 1995, 39, 1437-1441.

135 K. Hosokawa, Y. Fukunaga, E. Fukushi and J. Kawabata, Phytochemistry, 1996, 42, 671-672.

136 K. Hosokawa, Recent Res. Dev. Phytochem., 1998, 2, 135-141.

137 K. Hosokawa and Y. Fukunaga, Plant Cell Rep., 1995, 14, 575-579.

138 G. C. Kite, C. Sellwood, P. Wilkin and M. S. J. Simmonds, Biochem. Syst. Ecol., 1998, 26, 357-359.
139 N. Asano, A. Kato, M. Miyauchi, H. Kizu, Y. Kameda, A. A. Watson, R. J. Nash and G. W. J. Fleet, J. Nat. Prod., 1998, 61, 625-628.

140 M. Adinolfi, G. Barone, L. Dellagreca, L. Mangoni, R. Lanzetta and M. Parrilli, Gazz. Chim. Ital., 1990, 120, 427-433.

141 M. Adinolfi, T. Aquila, G. Barone, R. Lanzetta and M. Parrilli, Phytochemistry, 1989, 28, 3244-3246.

142 C. Dias, M. Dias, C. Borges, M. A. Almoster Ferreira, A. Paulo and J. Nascimento, J. Mass Spectrom., 2003, 38, 1240-1244.

143 A. Paulo, C. Dias, M. L. Jimeno, C. Borges and J. Nascimento, Fitoterapia, 2005, 76, 765-767.

144 C. Dias, A. Paulo, J. Nascimento, P. Houghton, J. E. Hawkes and M. L. Goncalves, Planta Med., 2003, 69, 1060-1062.

145 S. D. Wood, A. K. Allen, L. M. Wright and C. D. Reynolds, Lectins: Biol., Biochem., Clin. Biochem., 1997, 11, 86-90.

146 S. D. Wood, L. M. Wright, C. D. Reynolds, P. J. Rizkallah, A. K. Allen, W. J. Peumans and E. J. M. Van Damme, Acta Crystallogr., Sect. D: Biol. Crystallogr., 1999, 55, 1264-1272.

147 L. M. Wright, P. J. Rizkallah, S. D. Wood and C. D. Reynolds, Acta Crystallogr., Sect. D: Biol. Crystallogr., 1998, 54, 665667.

148 L. M. Wright, S. D. Wood, C. D. Reynolds, P. J. Rizkallah and A. K. Allen, Acta Crystallogr., Sect. D: Biol. Crystallogr., 1998, 54, 90-92.

149 L. M. Wright, S. D. Wood, C. D. Reynolds, P. J. Rizkallah, W. J. Peumans, E. J. M. Van Damme and A. K. Allen, Acta Crystallogr., Sect. D: Biol. Crystallogr., 1996, 52, 1021-1023.

150 L. M. Wright, C. D. Reynolds, P. J. Rizkallah, A. K. Allen, E. J. Van Damme, M. J. Donovan and W. J. Peumans, FEBS Lett., 2000, 468, 19-22.

151 A. Kato, I. Adachi, M. Miyauchi, K. Ikeda, T. Komae, H. Kizu, Y. Kameda, A. A. Watson, R. J. Nash, M. R. Wormald, G. W. J. Fleet and N. Asano, Carbohydr. Res., 1999, 316, 95-103.

152 A. A. Watson, R. J. Nash, M. R. Wormald, D. J. Harvey, S. Dealler, E. Lees, N. Asano, H. Kizu, A. Kato, R. C. Griffiths, A. J. Cairns and G. W. J. Fleet, Phytochemistry, 1997, 46, 255-259.

153 J. L. Thompson and J. K. N. Jones, Can. J. Chem., 1964, 42, 1088-1091.

154 C. Koorbanally, N. R. Crouch and D. A. Mulholland, Biochem. Syst. Ecol., 2001, 29, 539-541.

155 D. Ngamga, J. Bipa, P. Lebatha, C. Hiza, J. Mutanyatta, M. Bezabih, P. Tane and B. M. Abegaz, Nat. Prod. Commun., 2008, 3, 769-777.

156 D. Ngamga, P. Tane, M. Bezabih and B. M. Abegaz, Planta Med., 2006, 72, 1009-1009.

157 F. Fusi, A. Ferrara, C. Koorbanally, N. R. Crouch, D. A. Mulholland and G. Sgaragli, J. Pharm. Pharmacol., 2008, 60, 489-497.

158 G. Amschler, A. W. Frahm, A. Hatzelmann, U. Kilian, D. Mueller-Doblies and U. Mueller-Doblies, Planta Med., 1996, 62, 534-539.

159 G. Amschler, A. W. Frahm, D. Muller-Doblies and U. MullerDoblies, Phytochemistry, 1998, 47, 429-436. 
160 A. Michalik, J. Hollinshead, L. Jones, G. W. J. Fleet, C.-Y. Yu, X.-G. Hu, R. van Well, G. Horne, F. X. Wilson, A. Kato, S. F. Jenkinson and R. J. Nash, Phytochem. Lett., 2010, 3, 136-138.

161 N. Moodley, D. A. Mulholland and N. R. Crouch, J. Nat. Prod., 2004, 67, 918-920.

162 N. R. Crouch, V. Bangani and D. A. Mulholland, Phytochemistry, 1999, 51, 943-946.

163 B. Ncube, J. F. Finnie and J. van Staden, S. Afr. J. Bot., 2011, 77, 387-396.

164 B. Ncube, J. F. Finnie and J. van Staden, S. Afr. J. Bot., 2012, 78, 246-251.

165 A. Langlois, D. A. Mulholland, G. D. Duncan, N. R. Crouch and T. J. Edwards, Biochem. Syst. Ecol., 2005, 33, 961-966.

166 C. A. Williams, J. B. Harborne and T. S. Crosby, Phytochemistry, 1976, 15, 349-350.

167 C. Koorbanally, S. Sewjee, D. A. Mulholland, N. R. Crouch and A. Dold, Phytochemistry, 2007, 68, 2753-2756.

168 V. Bangani, N. R. Crouch and D. A. Mulholland, Phytochemistry, 1999, 51, 947-951.

169 K. du Toit, A. Kweyama and J. Bodenstein, S. Afr. J. Sci., 2011, 107, 96-100.

170 B. M. Abegaz, Phytochem. Rev., 2002, 1, 299-310.

171 A. Silayo, B. T. Ngadjui and B. M. Abegaz, Phytochemistry, 1999, 52, 947-955.

172 S. O. Famuyiwa, K. F. Sichilongo, S. O. Yeboah and B. M. Abegaz, Phytochem. Lett., 2012, 5, 591-595.

173 P. Pillay, A. Phulukdaree, A. A. Chuturgoon, K. du Toit and J. Bodenstein, J. Ethnopharmacol., 2012.

174 F. Speta, Phyton (Horn, Austria), 1998, 38, 1-141.

175 L. Krenn and B. Kopp, Phytochemistry, 1998, 48, 1-29.

176 S. J. van der Walt, Onderstepoort J. Vet. Res., 1944, 20, 75-83.

177 N. Sapeika, S. Afr. Pharm. J., 1951, 1, 28-29.

178 D. G. Steyn, 15th Annual Report of the Director of Veterinary Services, 1929, pp. 777-803.

179 C. F. Juritz, 12th Annual Meeting of the South African Association for the Advancement of Science, 1914, 109-150.

180 A. Hutchings and S. E. Terblanche, S. Afr. Med. J., 1989, 75, 41-96.

181 M. F. Pfosser and F. Speta, Plant Syst. Evol., 2004, 246, 245263.

182 W. Kopaczewski, C. R. Hebd. Seances Acad. Sci., 1914, 158, 1520-1522.

183 W. Kopaczewski, Biochem. Z., 1914, 66, 501-508.

184 F. W. Smith, Analyst, 1921, 46, 178-179.

185 O. Krestynova-Telupilova and F. Santavy, Ceska Slov. Farm., 1957, 6, 207-209.

186 K. J. Kraus, E. Mutschler and H. Rochelmeyer, Arzneim. Forsch., 1969, 19, 322-328.

187 K. J. Kraus, E. Mutschler and H. Rochelmeyer, Pharm. Ztg., 1969, 114, 417-419.

188 F. Kaczmarek and I. Zygmunt, Herba Pol., 1974, 20, 330338.

189 E. Gliozheni and T. Bisha, Bul. Shkencave Nat., 1972, 26, 4350.

190 C. H. Boehringer, FR Pat. 1967-123308, 1967.

191 G. Tittel and H. Wagner, Planta Med., 1980, 39, 125-134.
192 M. Couladi and A. Loukis, Fitoterapia, 1987, 58, 57-58.

193 A. Aliaga, M. Fernandez, F. A. Vega and C. Dios, Acta Pol. Pharm., 1987, 44, 560-562.

194 M. Fernandez, M. Oses and C. Dios, An. R. Acad. Farm., 1987, 53, 292-295.

195 K. Okushima, Arch. Exp. Pathol. Pharmakol., 1922, 95, 258266.

196 J. Markwalder, Klin. Wochenschr., 1922, 1, 212-215.

197 A. Stoll, E. Suter, W. Kreis, B. B. Bussemaker and A. Hofmann, Helv. Chim. Acta, 1933, 16, 703-733.

198 W. Anders and G. Zeise, Med. Klin., 1952, 47, 1061-1063.

199 H. Haas, Med. Klin., 1967, 62, 121-126.

200 A. von Wartburg, Helv. Chim. Acta, 1966, 49, 30-42.

201 A. von Wartburg and J. Renz, Helv. Chim. Acta, 1959.

202 A. J. Verbiscar, J. Patel, T. F. Banigan and R. A. Schatz, J. Agric. Food Chem., 1986, 34, 973-979.

203 H. Lichti, P. Niklaus and A. von Wartburg, Helv. Chim. Acta, 1973, 56, 2083-2087.

204 B. Gorlich, Arzneim. Forsch., 1960, 10, 770-774.

205 A. von Wartburg, M. Kuhn and K. Huber, Helv. Chim. Acta, 1968, 51, 1317-1328.

206 L. Krenn, R. Ferth, W. Robien and B. Kopp, Planta Med., 1991, 57, 560-565.

207 B. Kopp, L. Krenn, M. Draxler, A. Hoyer, R. Terkola, P. Vallaster and W. Robien, Phytochemistry, 1996, 42, 513522.

208 L. Krenn, B. Kopp, S. Steurer and M. Schubert-Zsilavecz, J. Nat. Prod., 1996, 59, 612-613.

209 L. Krenn, M. Jelovina and B. Kopp, Fitoterapia, 2000, 71, 126-129.

210 M. Iizuka, T. Warashina and T. Noro, Chem. Pharm. Bull., 2001, 49, 282-286.

211 L. Krenn, B. Kopp, A. Deim, W. Robien and W. Kubelka, Planta Med., 1994, 60, 63-69.

212 I. Garcia-Jalon, F. A. Vega, M. Fernandez and T. Arrupe, Cienc. Ind. Farm., 1974, 6, 43-52.

213 I. Garcia-Jalon, F. A. Vega, M. Fernandez and L. Martinez Valls, Cienc. Ind. Farm., 1973, 5, 260-269.

214 F. A. Vega, C. Martin and I. Garcia-Jalon, An. R. Acad. Farm., 1969, 35, 291-296.

215 F. A. Vega, I. Garcia-Jalon, M. Fernandez and J. Renedo, Phytochemistry, 1972, 11, 2896.

216 F. A. Vega, C. Martin, M. Fernandez and I. Garcia-Jalon, Galenica Acta, 1970, 23, 3-48; (43-44-45), 79-96.

217 F. A. Vega and M. Fernandez, Naturwissenschaften, 1964, 51, 483-484.

218 M. Fernandez, F. A. Vega, T. Arrupe and J. Renedo, Sci. Pharm., 1976, 44, 307-314.

219 M. Fernandez, F. A. Vega, T. Arrupe and J. Renedo, Phytochemistry, 1972, 11, 1534.

220 M. Couladis, E. Verykokidou-Vitsaropoulou and S. Philianos, Fitoterapia, 1993, 64, 92.

221 F. A. Vega, An. R. Acad. Farm., 1976, 42, 81-94.

222 M. Fernandez, J. Renedo, T. Arrupe and F. A. Vega, Phytochemistry, 1975, 14, 586-586.

223 M. Fernandez, J. Renedo, T. Arrupe and F. A. Vega, Ciencia \& Industria Farmaceutica, 1974, 6, 386-390. 
224 M. Fernandez, F. A. Vega, T. Arrupe and J. Renedo, Galenica Acta, 1971, 24, 45-57.

225 T. Spies, W. Praznik, A. Hofinger, F. Altmann, E. Nitsch and R. Wutka, Carbohydr. Res., 1992, 235, 221-230.

226 W. Praznik and T. Spies, Carbohydr. Res., 1993, 243, 9197.

227 D. Fos, J. Giraldez, M. J. Renedo, M. Fernandez and F. A. Vega, Cienc. Ind. Farm., 1979, 11, 141-146.

228 M. J. Pascual-Villalobos and M. Fernandez, Ind. Crops Prod., 1999, 10, 115-120.

229 H. Bozcuk, M. Ozdogan, O. Aykurt, F. Topcuoglu, H. Ozturk, D. Ekinci, A. Karadeniz, A. Mutlu and D. Burgucu, Turk. J. Med. Sci., 2011, 41, 101-108.

230 S. E. Shyr and E. J. Staba, Planta Med., 1976, 29, 86-90.

231 L. Krenn, M. Jambrits and B. Kopp, Planta Med., 1988, 54, 227-232.

232 L. Krenn, A. Hufner, A. Kastenhuber and F. Speta, Phytochemistry, 2004, 65, 2881-2884.

233 B. Kopp, M. Unterluggauer, W. Robien and W. Kubelka, Planta Med., 1990, 56, 193-197.

234 L. Krenn, M. Bamberger and B. Kopp, Planta Med., 1992, 58, 284-285.

235 L. Krenn, B. Kopp, E. Griesmayer-Camus and W. Kubelka, Sci. Pharm., 1992, 60, 65-72.

236 C. F. Juritz, Chem. News J. Ind. Sci., 1923, 126, 69-70.

237 N. Moodley, N. R. Crouch and D. A. Mulholland, Phytochemistry, 2007, 68, 2415-2419.

238 J. M. Watt, Arch. Exp. Pathol. Pharmakol., 1927, 120, 65-76. 239 P. G. J. Louw, Onderstepoort J. Vet. Res., 1953, 26, 141-148.

240 R. Tschesche and K. H. Hottemann, Chem. Ber., 1953, 86, 392-395.

241 N. Sapeika, S. Afr. J. Med. Sci., 1944, 9, 31-32.

242 P. G. J. Louw, Onderstepoort J. Vet. Res., 1949, 22, 313-319.

243 P. G. J. Louw, Nature, 1949, 163, 30-31.

244 N. Sapeika, S. Afr. Med. J., 1950, 24, 912-913.

245 B. Isaacson, S. Afr. Med. J., 1950, 24, 901-912.

246 P. G. J. Louw, Onderstepoort J. Vet. Res., 1952, 25, 123-133.

247 P. Zoller and C. H. Tamm, Helv. Chim. Acta, 1953, 36, 17441756.

248 P. S. Steyn, F. R. van Heerden and R. Vleggaar, S. Afr. J. Chem., 1986, 39, 143-146.

249 L. Krenn, B. Kopp, M. Bamberger, E. Brustmann and W. Kubelka, Nat. Prod. Lett., 1993, 3, 139-143.

250 R. R. T. Majinda, R. D. Waigh and P. G. Waterman, Planta Med., 1997, 63, 188-190.

251 G. N. Foukaridis, E. Osuch, L. Mathibe and P. Tsipa, J. Ethnopharmacol., 1995, 49, 77-79.

252 J. Marx, E. Pretorius and M. J. Bester, J. Ethnopharmacol., 2006, 104, 315-321.

253 J. Marx, E. Pretorius, W. J. Espag and M. J. Bester, Environ. Toxicol. Pharmacol., 2005, 20, 26-34.

254 C. Koorbanally, D. A. Mulholland and N. R. Crouch, Biochem. Syst. Ecol., 2005, 33, 743-748.

255 M. Teshome, H. Kassa and K. Charles, Ethiop. J. Health Dev., 2010, 24, 175-179.

256 H. D. Neuwinger, African Ethnobotany: Poisons and Drugs, Chapman and Hall, London, 1994.
257 M. Miyakado, T. Kato, N. Ohno and K. Koshimizu, Phytochemistry, 1975, 14, 2717.

258 T. Pohl, C. Koorbanally, N. R. Crouch and D. A. Mulholland, Phytochemistry, 2001, 58, 557-561.

259 E. Dagne, W. Mammo, M. Alemu and I. Casser, Bull. Chem. Soc. Ethiop., 1994, 8, 85-89.

260 K. Shimada, E. Umezawa, T. Nambara and S. M. Kupchan, Chem. Pharm. Bull., 1979, 27, 3111-3114.

261 H. Lichti and A. von Wartburg, Helv. Chim. Acta, 1960, 43, 1666-1681.

262 A. L. Cogne, A. Marston, S. Mavi and K. Hostettmann, J. Ethnopharmacol., 2001, 75, 51-53.

263 F. R. Van Heerden, R. Vleggaar and L. A. P. Anderson, S. Afr. J. Chem., 1988, 41, 145-151.

264 A. R. Ndhlala, J. F. Finnie and J. van Staden, J. Ethnopharmacol., 2011, 133, 663-674.

265 N. R. Crouch, A. Langlois and D. A. Mulholland, Phytochemistry, 2007, 68, 1731-1734.

266 N. R. Crouch, K. du Toit, D. A. Mulholland and S. E. Drewes, Phytochemistry, 2006, 67, 2140-2145.

267 C. Koorbanally, D. A. Mulholland and N. R. Crouch, Biochem. Syst. Ecol., 2005, 33, 295-299.

268 N. A. Koorbanally, C. Koorbanally, A. Harilal, D. A. Mulholland and N. R. Crouch, Phytochemistry, 2004, 65, 3069-3073.

269 O. O. G. Amusan, J. D. Msonthi and L. P. Makhubu, Fitoterapia, 1997, 68, 185-186.

270 S. Abbas, S. Bashir, A. Khan, H. Mehmood Malik and H. Gilani Anwarul, Phytother. Res., 2012, 26, 704-708.

271 Y. B. Tripathi, A. V. Singh and G. P. Dubey, Current Science, 2001, 80, 1267-1269.

272 P. Shokeen, M. Bala and V. Tandon, Int. J. Antimicrob. Agents, 2009, 33, 86-91.

273 H. N. Thatoi, S. K. Panda, S. K. Rath and S. K. Dutta, Asian J. Plant Sci., 2008, 7, 260-267.

274 S. Rangaswami and S. S. Subramanian, J. Sci. Ind. Res., 1955, 14B, 131.

275 S. Rangaswami and S. S. Subramanian, J. Sci. Ind. Res., 1956, 15C, 80-81.

276 R. V. Rao and S. Rangaswami, Tetrahedron Lett., 1967, 8, 4563-4565.

277 S. Jha and S. Sen, Curr. Sci., 1980, 49, 273-274.

278 S. Jha and S. Sen, Planta Med., 1983, 47, 43-45.

279 S. Rangaswami and S. S. Subramanian, J. Sci. Ind. Res., 1954, 13B, 150.

280 S. Jha and S. Sen, Phytochemistry, 1981, 20, 524-526.

281 B. Kopp and M. Danner, Sci. Pharm., 1983, 51, 227237.

282 D. B. Deb and S. Dasgupta, Q. J. Crude Drug Res., 1976, 14, 49-60.

283 S. Jha and S. Sen, Nucleus (Calcutta), 1982, 25, 190192.

284 S. Jha and S. Sen, Indian J. Exp. Biol., 1980, 18, 291292.

285 S. Jha and S. Sen, Phytochemistry, 1981, 20, 1442-1443.

286 V. K. Saxena and P. K. Chaturvedi, J. Inst. Chem. (India), 1992, 64, 35-37. 
287 N. Sultana, K. Akter, N. Nahar, M. S. H. Khan, M. Mosihuzzaman, H. Sohrab Md and K. Krohn, Nat. Prod. Res., 2010, 24, 1018-1026.

288 M. M. Patil and S. G. Torne, Curr. Sci., 1980, 49, 276277.

289 S. Jha and S. Sen, Acta Bot. Indica, 1981, 9, 258-264.

290 S. R. Shenoy, M. N. S. Kameshwari, S. Swaminathan and M. N. Gupta, Biotechnol. Prog., 2006, 22, 631-637.

291 A. V. Deepak, G. Thippeswamy, M. N. Shivakameshwari and P. Salimath Bharathi, Biochem. Biophys. Res. Commun., 2003, 311, 735-742.

292 A. V. Deepak and P. Salimath Bharathi, Biochimie, 2006, 88, 297-307.

293 H. Mikail, P. Magiatis and A. Skaltsounis, Planta Med., 2010, 76, 1242-1242.

294 M. M. Abid Ali Khan, S. N. H. Zaidi, S. A. Musanna and N. Singh, Asian J. Exp. Biol. Sci., 2012, 3, 476-480.

295 R. P. Luyt, A. K. Jager and J. van Staden, S. Afr. J. Bot., 1999, 65, 443-445.

296 R. P. Luyt, A. K. Jager and J. van Staden, S. Afr. J. Bot., 1999, 65, 443-445.

297 L. Krenn, V. Stapf and B. Kopp, Sci. Pharm., 2000, 68, 421427.

298 L. Rakotobe, M. Berkal, H. Huet, C. Djediat, V. Jeannoda, L. Mambu, F. Crespeau and M. Edery, Food Chem. Toxicol., 2009, 47, 2289-2293.

299 R. Jaretzky and F. Scheermesser, DE Patent 1935-J52167, 1935.

300 A. Katz, Pharm. Acta Helv., 1954, 29, 77-80.

301 A. Katz, Experientia, 1956, 12, 285-286.

302 A. Katz, Helv. Chim. Acta, 1950, 33, 1420-1428.

303 A. Katz, Helv. Chim. Acta, 1953, 36, 1417-1423.

304 A. Katz, Helv. Chim. Acta, 1953, 36, 1344-1352.

305 A. Katz, Helv. Chim. Acta, 1954, 37, 833-836.

306 A. Katz, Helv. Chim. Acta, 1954, 37, 451-454.

307 A. Katz, Helv. Chim. Acta, 1955, 38, 1565-1572.

308 A. Katz, Helv. Chim. Acta, 1957, 40, 831-846.

309 A. Katz, Helv. Chim. Acta, 1958, 41, 1399-1404.

310 R. Tschesche and U. Dolberg, Chem. Ber., 1957, 90, 23782382.

311 R. Tschesche and U. Dolberg, Chem. Ber., 1958, 91, 25122523.

312 R. Tschesche, H. W. Sarau and K. Sellhorn, Chem. Ber., 1955, 88, 1612-1619.

313 R. Tschesche and K. Sellhorn, Chem. Ber., 1953, 86, 54-62. 314 R. Tschesche, S. Goenechea and G. Snatzke, Justus Liebigs Ann. Chem., 1964, 674, 176-184.

315 G. Schenck and F. Rattinger, US Patent 1951-21868, 1951.

316 M. A. Angarskaya, P. I. Bezruk and D. A. Tkachenko, Farmakol. i Toksikol., Sb., (Kiev Zdorov'c), 1964, 1, 20-25.

317 F. Hildebrandt and E. Paas, Naunyn-Schmiedebergs Arch. Pharmakol. Exp. Pathol., 1953, 220, 482-489.

318 F. Hildebrandt and W. Reinartz, Naunyn-Schmiedebergs Arch. Pharmakol. Exp. Pathol., 1953, 220, 290-294.

319 A. Katz, CH Patent 324078, 1957.

320 A. Katz, CH Patent 330660, 1958.

321 A. Katz, Pharm. Acta Helv., 1954, 29, 369-378.
322 K. K. Chen and F. G. Henderson, J. Pharmacol., 1951, 103, 420.

323 K. K. Chen and F. G. Henderson, J. Med. Chem., 1961, 3, 111-127.

324 K. K. Chen, J. Med. Chem., 1970, 13, 1029-1034.

325 C. Koorbanally, D. A. Mulholland and N. R. Crouch, Biochem. Syst. Ecol., 2005, 33, 545-549.

326 E. J. Ndebia, E. Umapathy, B. N. Nkeh-Chungag and J. E. Iputo, J. Med. Plants Res., 2011, 5, 4658-4664.

327 S. O. Oyedemi, G. Bradley and A. J. Afolayan, J. Med. Plants Res., 2009, 3, 1040-1044.

328 T. Okanishi, A. Akahori, F. Yasuda, Y. Takeuchi and T. Iwao, Chem. Pharm. Bull., 1975, 23, 575-579.

329 M. Kuroda, Y. Mimaki, Y. Sashida, T. Yamori and T. Tsuruo, Tennen Yuki Kagobutsu Toronkai Koen Yoshishu, 1999, 41, 529-534.

330 Y. Mimaki, M. Kuroda, Y. Sashida, T. Yamori and T. Tsuruo, Helv. Chim. Acta, 2000, 83, 2698-2704.

331 M. Kuroda, Y. Mimaki, Y. Sashida, T. Yamori and T. Tsuruo, Tetrahedron Lett., 2000, 41, 251-255.

332 Y. Mimaki, M. Kuroda, A. Yokosuka and Y. Sashida, J. Nat. Prod., 2001, 64, 1069-1072.

333 M. Kuroda, Y. Mimaki, A. Yokosuka and Y. Sashida, Chem. Pharm. Bull., 2001, 49, 1042-1046.

334 P. Tang and B. Yu, Angew. Chem., Int. Ed., 2007, 46, 25272530.

335 P. Tang and B. Yu, Eur. J. Org. Chem., 2009, 259-269.

336 K. du Toit, PhD Thesis, University of Natal, South Africa, 2004.

337 F. Klar, Planta Med., 2011, 77, 1274-1274.

338 S. Kubo, Y. Mimaki, M. Terao, Y. Sashida, T. Nikaido and T. Ohmoto, Phytochemistry, 1992, 31, 3969-3973.

339 S. Kubo, Y. Mimaki, Y. Sashida, T. Nikaido and T. Ohmoto, Chem. Pharm. Bull., 1992, 40, 2469-2472.

340 M. Kuroda, Y. Mimaki, Y. Sashida, T. Nikaido and T. Ohmoto, Tetrahedron Lett., 1993, 34, 6073-6076.

341 M. Kuroda, Y. Mimaki, Y. Sashida, T. Hirano, K. Oka and A. Dobashi, Chem. Pharm. Bull., 1995, 43, 12571259.

342 M. Kuroda, Y. Mimaki and Y. Sashida, Phytochemistry, 1999, 52, 435-443.

343 T. Hirano, K. Oka, Y. Mimaki, M. Kuroda and Y. Sashida, Life Sci., 1996, 58, 789-798.

344 M. Kuroda, Y. Mimaki, Y. Sashida, T. Hirano, K. Oka, A. Dobashi, H.-Y. Li and N. Harada, Tetrahedron, 1997, 53, 11549-11562.

345 Y. Mimaki and Y. Sashida, Adv. Exp. Med. Biol., 1996, 404, 101-110.

346 Y. Mimaki, M. Kuroda, A. Kameyama, Y. Sashida, T. Hirano, K. Oka and A. Dobashi, Bioorg. Med. Chem. Lett., 1996, 6, 2635-2638.

347 Y. Mimaki, M. Kuroda, Y. Sashida, T. Hirano, K. Oka, A. Dobashi, H. Koshino and J. Uzawa, Tetrahedron Lett., 1996, 37, 1245-1248.

348 Y. Sashida, Stud. Plant Sci., 1999, 6, 201-211.

349 M. Kuroda, Y. Mimaki, H. Koshino and Y. Sashida, Heterocycles, 2002, 56, 531-536. 
350 Y. Mimaki, M. Kuroda, A. Kameyama, Y. Sashida, T. Hirano, K. Oka, K. Koike and T. Nikaido, Biosci., Biotechnol., Biochem., 1996, 60, 1049-1050.

351 Y. Mimaki, M. Kuroda, A. Kameyama, Y. Sashida, T. Hirano, K. Oka, R. Maekawa, T. Wada, K. Sugita and J. A. Beutler, Bioorg. Med. Chem. Lett., 1997, 7, 633-636.

352 M. Kuroda, Y. Mimaki and Y. Sashida, Phytochemistry, 1999, 52, 445-452.

353 M. Kuroda, Y. Mimaki, A. Yokosuka, Y. Sashida and J. A. Beutler, J. Nat. Prod., 2001, 64, 88-91.

354 Y. Sashita, K. Oka, T. Hirano, Y. Mimaki, A. Kuroda, A. Fujii and Y. Myata, JP Patent 1996-109329, 1996.

355 Y. Sashita, K. Oka, T. Hirano, Y. Mimaki, A. Kuroda, A. Fujii and Y. Myata, JP Patent 1996-107254, 1996.

356 Y. Sashita, K. Oka, T. Hirano, Y. Mimaki, A. Kuroda, A. Fujii and Y. Myata, JP Patent 1996-107255, 1996.

357 Y. Hui, Z. Yang and Q. Ge, CN Patent 2006-10147244, 2006.

358 Y. Hui, Z. Yang, C. Yu, Q. Ge and L. Bao, CN Patent 200610116980, 2006.

359 Y. Zhou, C. Garcia-Prieto, D. A. Carney, R.-H. Xu, H. Pelicano, Y. Kang, W. Yu, C. Lou, S. Kondo, J. Liu, D. M. Harris, Z. Estrov, M. J. Keating, Z. Jin and P. Huang, J. Natl. Cancer Inst., 2005, 97, 1781-1785.

360 W. Ying, Y.-L. Wu, X.-C. Feng, L.-H. Lian, Y.-Z. Jiang and J.-X. Nan, J. Ethnopharmacol., 2010, 132, 450-455.

361 Y. Wan, Y.-L. Wu, L.-H. Lian and J.-X. Nan, Chin. J. Nat. Med., 2012, 10, 0177-0184.

362 R. A. Waud, J. Pharmacol. Exp. Ther., 1951, 101, 36-36.

363 R. A. Waud and J. Boyd, J. Pharmacol. Exp. Ther., 1954, 111, 147-151.

364 R. A. Waud and J. Boyd, Rev. Can. Biol., 1952, 11, 88.

365 A. Vogelsang, Can. Med. Assoc. J., 1955, 73, 295-296.

366 H. Mrozik, R. A. Waud, O. Schindler and T. Reichstein, Helv. Chim. Acta, 1959, 42, 683-696.

367 R. B. Kelly, E. G. Daniels and L. B. Spaulding, J. Med. Chem., 1965, 8, 547-548.

368 F. E. Hart and G. R. Paterson, Can. J. Pharm. Sci., 1968, 3, 15-18.

369 J. A. Smith and G. R. Paterson, J. Pharm. Pharmacol., 1967, 19, 221-225.

370 R. Ferth and B. Kopp, Die Pharmazie, 1992, 47, 626-629.

371 Y. Buchvarov, M. Pargov and K. Akhtardzhiev, Farmatsiya (Sofia, Bulg.), 1976, 26, 31-34.

372 O. Gasic, V. Simanek, V. Lukic, D. Walterova, S. Kevresan, V. Hanus and B. Pal, Zb. Matice Srp. Prir. Nauke, 1989, 76, 21-26.

373 O. Azzioui, R. L. Braemer and M. Paris, Biochem. Syst. Ecol., 1989, 17, 449-450.

374 T. Sabudak and U. Oyman, Turk. J. Chem., 2002, 26, 453455.

375 W. Schliemann, J. Schmidt, M. Nimtz, V. Wray, T. Fester and D. Strack, Phytochemistry, 2006, 67, 1196-1205.

376 N. F. Komissarenko, Khim. Prir. Soedin., 1971, 7, 38-40.

377 N. F. Komissarenko, Postep Dziedzinie Leku Rosl., Pr. Ref. Dosw. Wygloszone Symp., 1972, 67-71.

378 I. G. Zoz and N. A. Chernykh, Farm. Zh. (Kiev), 1969, 24, 7778.
379 N. F. Komissarenko, Khim. Prir. Soedin., 1969, 5, 46-48.

380 N. F. Komissarenko, Khim. Prir. Soedin., 1965, 156-160.

381 N. F. Komissarenko, Khim. Prir. Soedin., 1969, 5, 46-48.

382 N. F. Komissarenko, Khim. Prir. Soedin., 1972, 397-398.

383 R. Ferth, A. Baumann, W. Robien and B. Kopp, $Z$. Naturforsch., B: J. Chem. Sci., 1992, 47, 1459-1467.

384 R. Ferth, A. Baumann, W. Robien and B. Kopp, $Z$. Naturforsch., B: J. Chem. Sci., 1992, 47, 1444-1458.

385 N. F. Komissarenko and P. E. Krivenchuk, Khim. Prir. Soedin., 1974, 10, 257.

386 U. Ghannamy, B. Kopp, W. Robien and W. Kubelka, Planta Med., 1987, 53, 172-178.

387 V. A. Bandyukova, Chem. Nat. Compd., 1979, 15, 639.

388 M. Nicoletti, L. Tomassini and S. Foddai, Planta Med., 1992, 58, 472.

389 V. V. Barbakadze, E. P. Kemertelidze, H. E. Dekanosidze and A. I. Usov, Bioorg. Khim., 1993, 19, 912-916.

390 Y. Buchvarov, E. Balabanova-Radonova, I. Radenkova and S. Vankov, Farmatsiya (Sofia, Bulg.), 1984, 34, 33-37.

391 A. A. Makasci, R. Mammadov, O. Dusen and H. I. Isik, J. Med. Plants Res., 2010, 4, 1637-1642.

392 E. Nazifi, A. Movafeghi, H. Nazemiyeh, S. Asnaashari, S. Bamdad Moghadam and A. Delazar, Ulum-i Daroei, 2010, 16, 37-44.

393 A. Delazar, E. Nazifi, A. Movafeghi, H. Nazemiyeh, S. Hemmati, L. Nahar and S. D. Sarker, Bol. Latinoam. Caribe Plant. Med. Aromat., 2010, 9, 87-92.

394 A. Delazar, E. Nazifi, A. Movafeghi, L. Nahar, H. Nazemiyeh, S. B. Moghadam, S. Asnaashari and S. D. Sarker, Daru, J. Fac. Pharm., Tehran Univ. Med. Sci., 2009, 17, 33-36.

395 M. A. Ebrahimzadeh, S. M. Nabavi, S. F. Nabavi and B. Eslami, Trop. J. Pharm. Res., 2010, 9, 141-148.

396 S. Kubo, Y. Mimaki, Y. Sashida, T. Nikaido and T. Ohmoto, Bull. Chem. Soc. Jpn., 1992, 65, 1120-1124.

397 M. Kuroda, Y. Mimaki, A. Yokosuka, F. Hasegawa and Y. Sashida, J. Nat. Prod., 2002, 65, 1417-1423.

398 M. Kuroda, Y. Mimaki, K. Ori, H. Sakagami and Y. Sashida, J. Nat. Prod., 2004, 67, 1690-1696.

399 M. Kuroda, K. Ori and Y. Mimaki, Steroids, 2006, 71, 199205.

400 M. Kuroda, Y. Mimaki, A. Yokosuka, F. Hasegawa and Y. Sashida, J. Nat. Prod., 2002, 65, 1417-1423.

401 M. Kuroda, Y. Mimaki, K. Ori, H. Sakagami and Y. Sashida, J. Nat. Prod., 2004, 67, 1690-1696.

402 W. T. Mabusela and A. M. Stephen, Carbohydr. Res., 1990, 207, 332-335.

403 D. A. Mulholland, N. R. Crouch, T. Pohl and E. Ndlovu, Biochem. Syst. Ecol., 2004, 32, 499-502.

404 M. van Huyssteen, P. J Milner, E. E. Campbell and M. van de Venter, Afr. Networks Ethnomed., 2011, 8, 150-158.

405 Y. Tang, B. Yu, J. Hu, T. Wu and H. Hui, J. Nat. Prod., 2002, 65, 218-220.

406 T. Xu, Y. Xu, D. Liu and D. Xu, Yaoxue Xuebao, 2000, 35, 3236.

407 Y. P. Tang, B. Yu, J. Hu, T. Wu and H. Z. Hui, J. Nat. Prod., 2002, 65, 218-220. 
408 Y. Tang, B. Yu, J. Hu, T. Wu and Y. Hui, J. Chin. Pharm. Sci., 2001, 10, 169-171.

409 J. F. Bai, Z. Q. Liu, S. M. Wang, F. R. Song and S. Y. Liu, Chem. J. Chin. Univ., 2005, 26, 1817-1819.

410 Z. Han, CN Patent 2001-18727, 2001.

411 Z. Han, CN Patent 2006-10115717, 2006.

412 X. Lu and Z. Han, CN Patent 2004-10074137, 2004.

413 G. I. Mynkina, RU Patent 1999-108770, 1999.

414 J. Sun, G. Lu and L. Xiu, CN Patent 2010-10177347, 2010.

415 X. Jin, G. Cui, C. Qian, X. Du and Y. Wu, Shizhen Guoyi Guoyao, 2010, 21, 124-126.

416 C. Qian, X. Jin, Y. Wu and X. Li, Shizhen Guoyi Guoyao, 2010, 21, 636-638.
417 L. Shi, J. Li, W.-X. Liu, Y. Wang, Z.-Q. Liu and S.-Y. Liu, Chem. Res. Chin. Univ., 2003, 19, 286-289.

418 R. Chen, S. Li, Z. Liu, H. Dong, Y. Li and S. Yang, Zhongguo Yaoxue Zazhi (Beijing, China), 2011, 46, 1630-1634.

419 R. Chen, F. Meng, Z. Liu, R. Chen and M. Zhang, Carbohydr. Polym., 2010, 80, 845-851.

420 X. Liu and Y.-H. Zhang, Shizhen Guoyi Guoyao, 2012, 23, 1388-1390.

421 O. Q. Munro, K. du Toit, S. E. Drewes, N. R. Crouch and D. A. Mulholland, New J. Chem., 2006, 30, 197-207.

422 Y. Sashida, Stud. Plant Sci., 1999, 6, 201-211.

423 Y. Mimaki, Nat. Prod. Commun., 2006, 1, 247-253.

424 E. R. Guaglianone and S. Arroyo-Leuenberger, Darwiniana, 2002, 40, 61-76. 